\title{
Mapping the Growth of an Arabian Gulf Town: the case of Doha, Qatar
}

\section{Part I. The Growth of Doha: Historical and Demographic Framework}

\section{Introduction}

In this paper we use GIS to anatomize Doha, from the 1820 s to the late 1950 s, as a case study of an Arab town, an Islamic town, and a historic Arabian Gulf town. We use the first two terms advisedly, drawing attention to the contrast between the ubiquitous use of these terms versus the almost complete lack of detailed studies of such towns outside North Africa and Syria which might enable a viable definition to be formulated in terms of architecture, layout and spatial syntax. In this paper we intend to begin to provide such data. We do not seek to deny the existence of similarities and structuring principles that cross-cut THE towns and cities of the Arab and Islamic world, but rather to test the concepts, widen the dataset and extend the geographical range of such urban studies, thereby improving our understanding of them.

Doha was founded as a pearl fishing town in the early $19^{\text {th }}$ century, flourished during a boom in pearling revenues in the late 19 th and early $20^{\text {th }}$ century, and, after a period of economic decline following the collapse of the pearling industry in the 1920s, rapidly expanded and modernized in response to an influx of oil revenues beginning in 1950 (Othman, 1984; Graham, 1978: 255). ${ }^{1}$ As such it typifies the experience of nearly all Gulf towns, the vast majority of which were also founded in the $18^{\text {th }}$ or early $19^{\text {th }}$ century as pearl fishing settlements, and which experienced the same trajectory of growth, decline and oil-fuelled expansion (Carter 2012: 115-124, 161-169, 275-277). ${ }^{2}$ Doha is the subject of a multidisciplinary study (The Origins of Doha and Qatar Project), and this paper comprises the first output of this work, which was made possible by NPRP grant no. 5-421-6-010 from the Qatar National Research Fund (a member of Qatar Foundation) ${ }^{3}$. The statements made herein are solely the responsibility of the authors.

\footnotetext{
1 The first consignment of crude oil left Qatar's shore on the last day of 1949.

2 Doha is also, most importantly, a port town. There is a great deal to be said on this subject and much research still to be done. Nelida Fuccaro has recently published an excellent examination of the Gulf towns as ports (Fuccaro 2014), which will inspire a great deal more research on Doha in our future work.

3 The Origins of Doha and Qatar Project not only includes investigation of urban syntax, but also detailed exploration of the lived experience of the people of the town. The project examines Doha structurally and systematically and considers its development as a dynamic urban environment created through the agency of its people. The GIS work presented here is just one component of an interdisciplinary work including archaeological excavation, architectural recording, and ethnography intended to give a comprehensive account of Doha and its people.
} 
The ideas of the Arab City and the Islamic City (and indeed the "Arab and Islamic City") endures as a tenacious organizing construct and a powerful trope in the study of urban historical and cultural geography. It is in essence an Orientalist construct which began with Weber's Die Stadt. Eine soziologische Untersuchung (1921) and had its swan song with von Grunebaum's 1955 The Structure of the Muslim Town (von Grunebaum, 1955), after which a long line of scholars have worked to reveal its errors and limitations. By 1987 Janet Abu-Lughod was able to go so far as to describe "the isnād [authorititative descent] of the Islamic city" and point out the "preposterous nature of some of the basic presuppositions of Orientalism" to be found within it (Abu-Lughod, 1987; Raymond, 1994: 12). As pointed out by Raymond (1994) and others, it is highly problematic that towns and cities across the whole of the Middle East and North Africa, let alone the entire Islamic world, should be defined with one set of characteristics originally formulated through the work of a single influential school of thought (Lespès, 1930; Sauvaget, 1934; Weulersse and Demangeon, 1935), based on studies limited to a handful of major towns in north Africa and Syria. That such a construct should also be ahistorical, in the sense of presenting an unchanging set of precepts that are particular to Arabs or Muslims, is equally problematic.

Empirical data is particularly lacking for eastern Arabia, and the lacuna is cavernous with regards to the Gulf itself. Recent literature on cities in the wider Islamic world either focuses on medieval urbanism (Bennison \& Gascoigne 2007); or looks only to recent post-oil development, with a particular emphasis on $20^{\text {th }}$ century town planning and architecture, and there is a lack of comparative studies (as noted by Fuccaro 2009). They also tend to omit any significant mention of the towns of the Gulf. For example Jayyusi et al. (2008), a monumental compilation of 46 studies and 1142 pages which covers cities throughout the Islamic world, includes only Dubai in the Gulf region, in which the historic aspect of the city is accorded just two paragraphs, on a single (atypical) district, Bastakiyah (Haider 2008). Other studies of urban form and historical development in eastern Arabia and the Gulf are laudable but limited to small districts, including further studies of Bastakiyah in Dubai (Boussaa 2006), Manama Souq and Suq Waqif in Doha (Alraouf 2012; Boussaa 2014a), Al-Asmakh in Doha (Boussaa 2014b), and the Kut area of Hofuf, Saudi Arabia (Hakim 1994). None take a GIS-based analytical approach of the traditional town, and detailed urban plans are absent or limited in scale or data content. This is not intended to be a criticism, as these publications had different aims from our own, including post-oil urban development, 
architectural conservation, urban regeneration and Islamic law. However, we consider this to be a gap in the research which needs to be addressed.

Notable exceptions include Fuccaro's detailed treatment of Manama (Bahrain), which is an excellent work of history but does not consider urban form, as well as Yarwood's (1988; 2005) and Al-Sulaiti's (2009) examinations of Muharraq. Yarwood's work covers only a small part of the town, however, while Al-Sulaiti's is concerned with historical growth and contemporary heritage development, and is not yet directed towards a detailed consideration of urban form and syntax. Honourable mention must also go to Bandyopadhyay's detailed study of Manah (Bandyopadhyay 2010), a small town of interior Oman, which is of completely different aspect to Doha and previous case studies in the region, and which provides a valuable point of comparison (to be addressed in future work) as well as an illustration of the variability inherent in the wider dataset. Bhandyopadhyay and his team have additionally produced grey literature on interior settlements in Oman in which GIS analysis of urban form is undertaken, and which will provide equally valuable points of comparison (Bandyopadhyay et al. 2015a; Bandyopadhyay et al. 2015b).
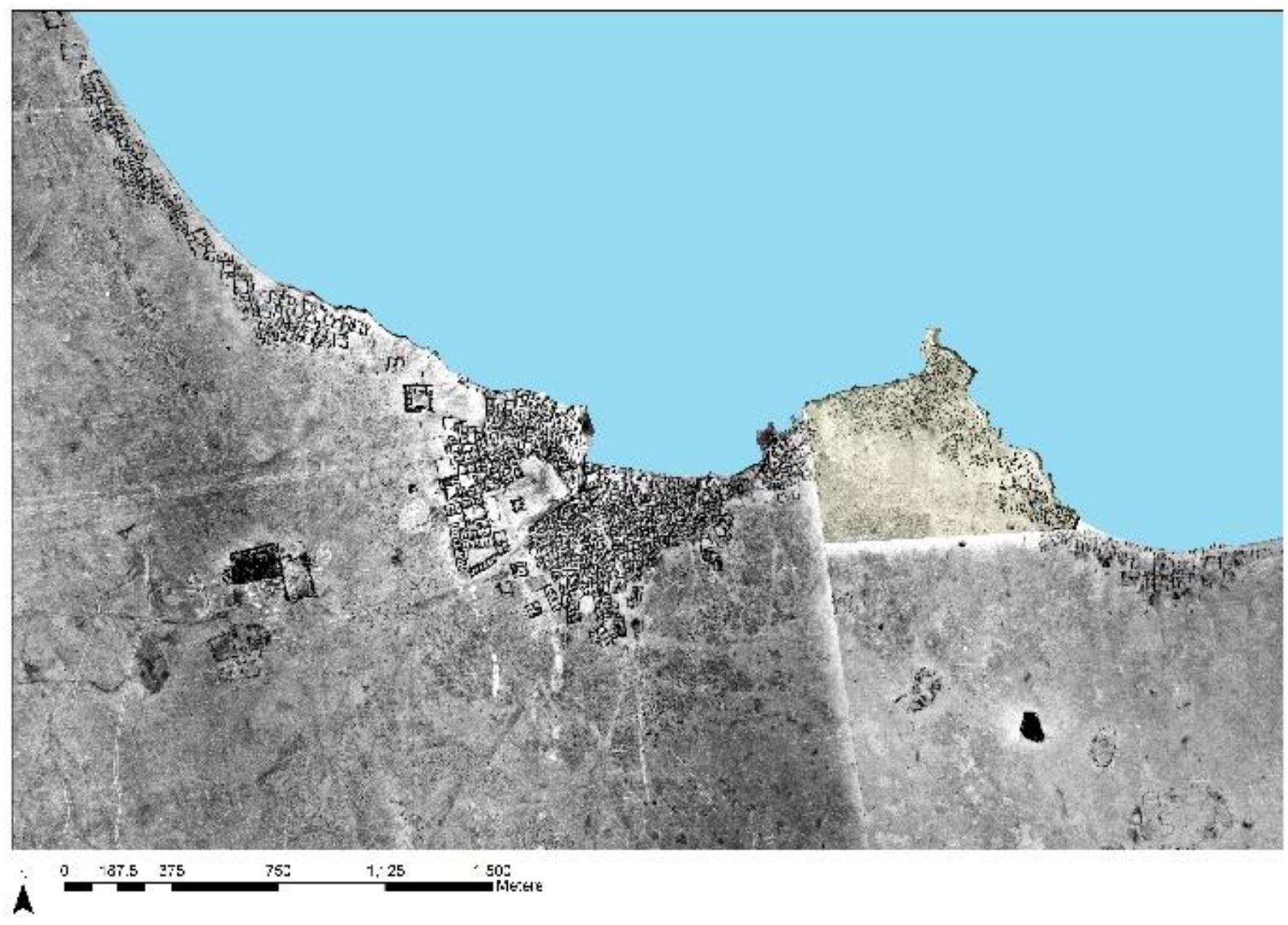


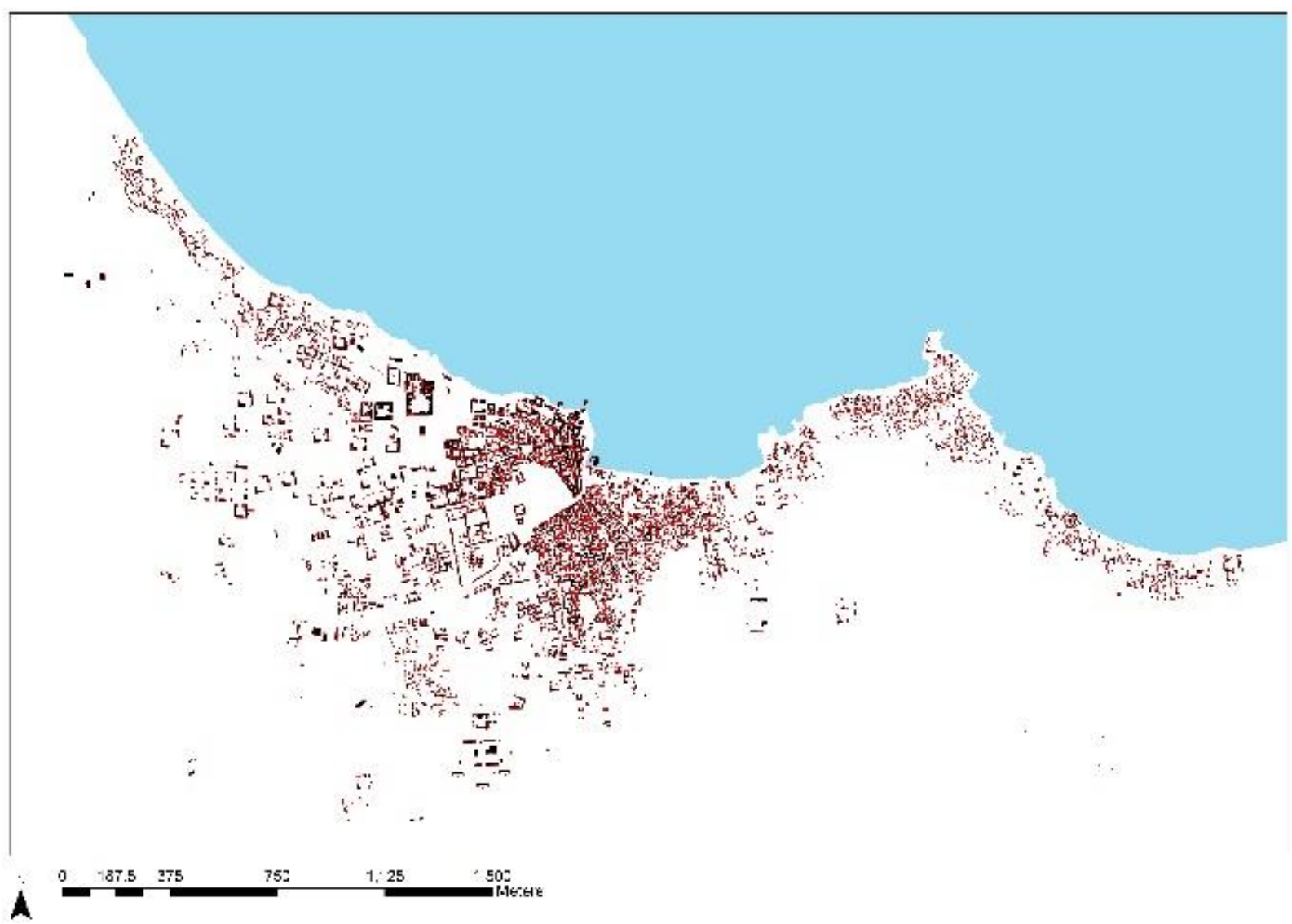

Figure 1: 1947 aerial of Doha and the digital map of Doha in 1952 - the final manifestation of the traditional town.

\section{The Growth of Doha and its Districts}

Here we present an original attempt to interrogate the construct of the Arab city against rigorously collected evidence and meticulous analysis of historical urban geography. We have accordingly mapped Doha and its districts of Doha from the 1820s to the 1960s, using historical accounts, maps and aerial imagery, and incorporated the results into a GIS package which includes every house, wall and construction. The results of our subsequent analyses are given below, and represent a first in the scholarship of the Arab city.

Doha existed from at least the early $19^{\text {th }}$ century, based upon the maps and testimony of diplomats, mariners and cartographers. We have mapped the growth of Doha, and (tentatively) the location and names of its districts (firjān, sing. farī̄) between 1823 and 1956, using a combination of maps and textual sources (figs. 1-8). Its oldest district was Bida', originally a separate town said to have been founded by the Sudan tribe, and mentioned by the British sea captain Seton in 1802 (Seton 1995: 27). British documents indicate that the Sudan moved there in summer 1801 from Hormuz, having recently fled 
there from Oman after falling out with their former patron, the Sultan of Muscat (Davies 1997: 78, 342). By 1823 Doha itself had been founded less than $2 \mathrm{~km}$ away, as demonstrated by a British map of that year (fig. 1); later sources indicate that Doha had been founded by the Al Bu 'Ainain tribe (Lorimer 1908: 488). Given the good water sources around the bay, it is possible that a town existed for some time in the area before the stated foundation dates. This is suggested by a problematic document of 1681 which appears to mention Bida' ("Bide”) (Billecocq 2008: 14)4.

Over time, numerous new districts were added to the original towns of Bida' and Doha, starting with Little Doha (Dohat Al-Saghir, later Duwaiha), which lay in between the two and is visible on Constable and Stiffe's map of 1860 (fig. 3). Following a final violent destruction episode in 1867 (see below, Section []), growth appears to have been fairly steady during the final decades of the $19^{\text {th }}$ century and the early $20^{\text {th }}$, such that by 1908 , according to Lorimer, Bida' and Doha had joined together and were regarded as districts within a single large conurbation of districts which was then collectively known as Doha (formerly collectively known as Bida').The exact date of the founding of each new district remains speculative at this stage, but clues are offered by the historical sources and imagery. For example, both Lorimer and Burchardt's written reports indicate that Salata existed by the middle of the first decade of the $20^{\text {th }}$ century. Apart from Bida' and Doha, Lorimer also lists Rumaila (a new spread to the northwest of Bida'); Margab Al-Gharbi, Qala'at Al-Askar and Duwaiha (between Bida' and Doha); Margab AlSharqi, Salata and Al Bin Ali (later Hitmi). Additionally a clearly defined district known to mid-20 th century mappers as Ahl al-Nejd ("people of the Nejd") ${ }^{5}$ was probably already in existence by Lorimer's day: he notes the presence of people from Nejd living on the inland side of the old Doha district, and its only surviving house (that of Mohammed Said Nasr Allah) yielded a deed of sale dating to $1341 \mathrm{AH}$ (1922) when it was bought by its second owner (Kholaifi 2006: 145).

\footnotetext{
${ }^{4} \mathrm{~A}$ report from a Franciscan missionary purportedly mentions a small settlement and fort at "Bide" and is cited by Billecocq X.B. 2008, Le Qatar et les Français, p. 14. It is problematic in that it mentions towns which are not considered to have been in existence at the time, including Zubarah, Fuwairit and Al-Khor (which additionally appears to have been known only as Shaqiq prior to the $20^{\text {th }}$ century). Conversely it does not mention those few towns which are considered to have existed in Qatar prior to the $18^{\text {th }}$ century, including Huwailah, widely referenced as the major town of Qatar prior to the $18^{\text {th }}$ century, and Furaihah, which is mentioned as early as 1700 and for which a $17^{\text {th }} /$ early $18^{\text {th }}$ century occupation is archaeologically attested. Unlike the other documents given in Billlecocq's book no facsimile is presented, and no precise reference to its whereabouts is given. However, it is wholly plausible that a settlement with a fort existed around Bida' at that time, and the historical sources are notoriously incomplete. This source merits further exploration.

${ }^{5}$ The mappers (Hunting Survey) may have been misled as to the name of this district, which lay between the suq and the later district of Najada (whose name also refers to the Nejd). Later observers (e.g. Kholaifi 2006) include houses in this area in Barahat Al-Jufairi
} 
Most of the remaining traditional districts of Doha were outlined and named in the first 1952 map of Doha by Hunting Survey. All were visible in a 1937 aerial of the town, and we infer these were founded between Lorimer's day and 1937. These including Al-Hala, which joined Salata to old Doha, a southern spread comprising Barahat Al-Jufairi, Ahmad Bajeis and Amadahia, and a southwestern addition named after Mohammed Bin Jasim. It is unknown whether Kholaifat, at the eastern tip of the conurbation, was already present in 1937 as it is beyond the frame of the 1937 image.

Certain districts today considered part of old Doha were not actually founded until after 1950, most notably Msheireb (though an early $20^{\text {th }}$ century southern extension of Jasra was later considered part of Msheireb), Najada and Al-Asmakh.
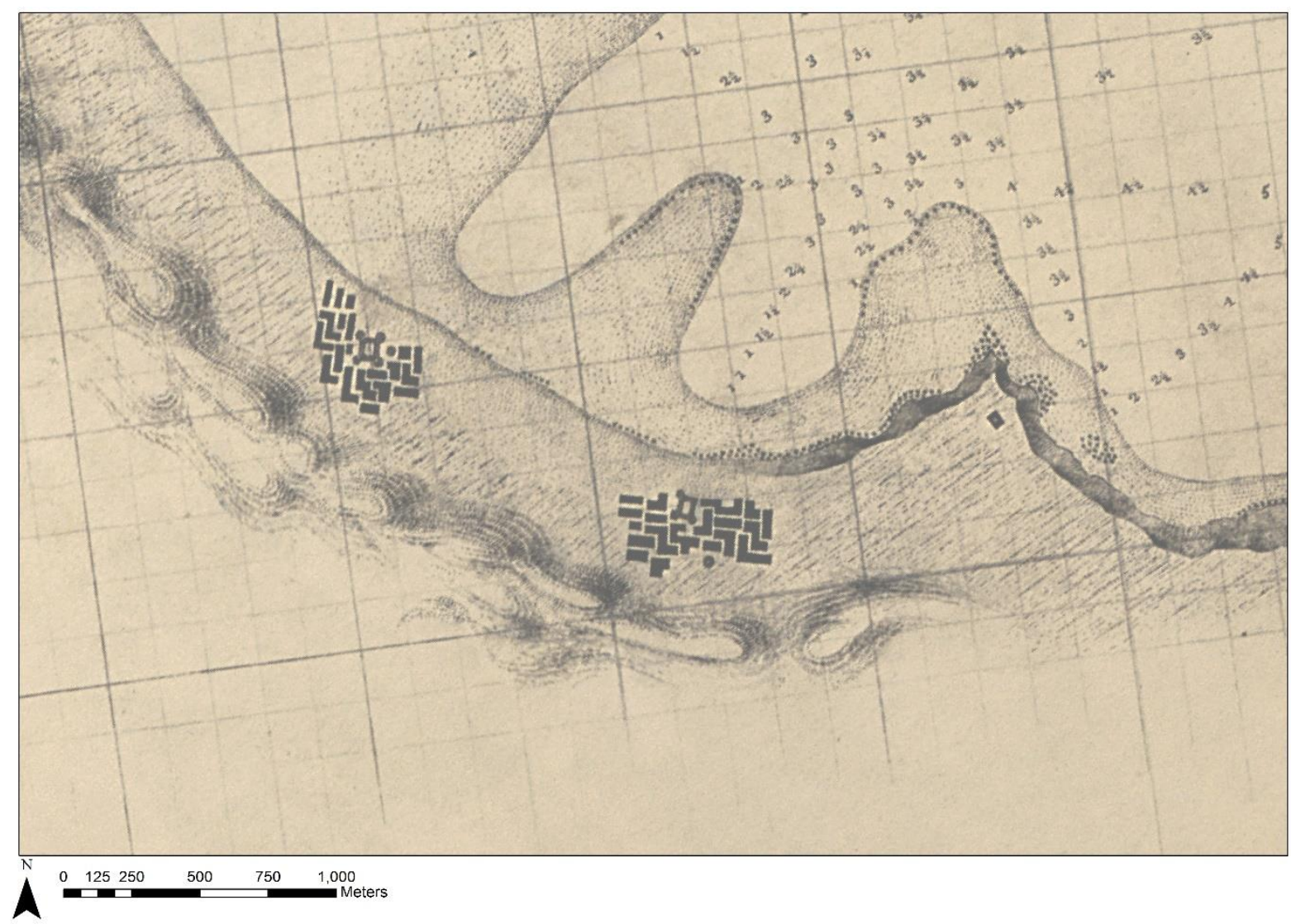

Figure 2: Original map of Bida' and Doha in 1823, by Lieuts. J.M. Guy and G.B. Brucks. Source: British Library, Oriental and India Office Collections. 


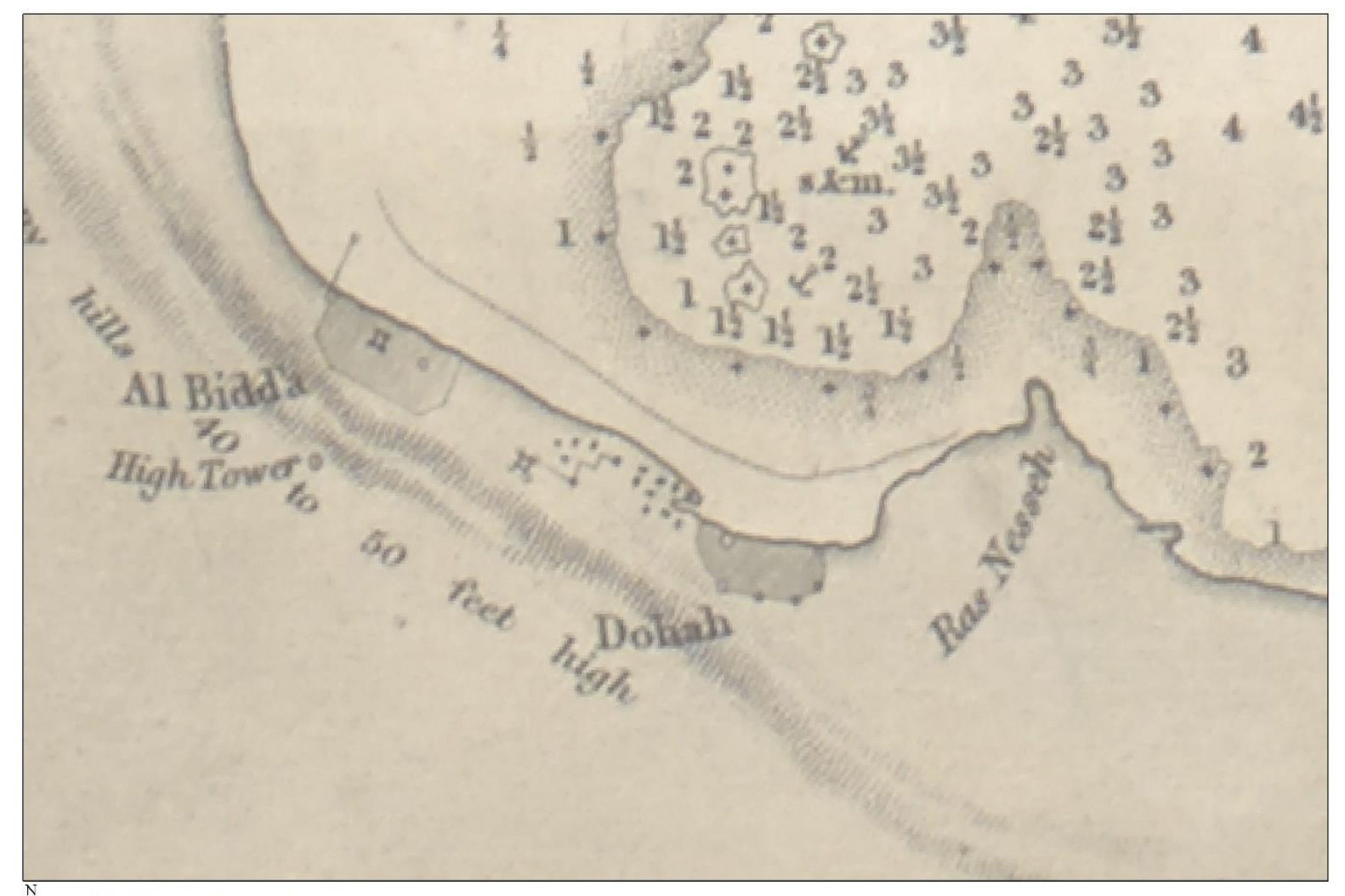



Figure 3: Original map of Bida' and Doha in 1860. Source: British Library, Oriental and India Office Collections.



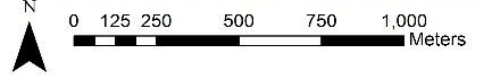

Figure 4: Districts of the conurbation (then known as collectively as Bida') in 1860. The name and outline of Doha Saghira is supplied by Constable and Stiffe's verbal description that accompanies the map shown on the previous figure (Constable \& Stiffe 1989: 105). 


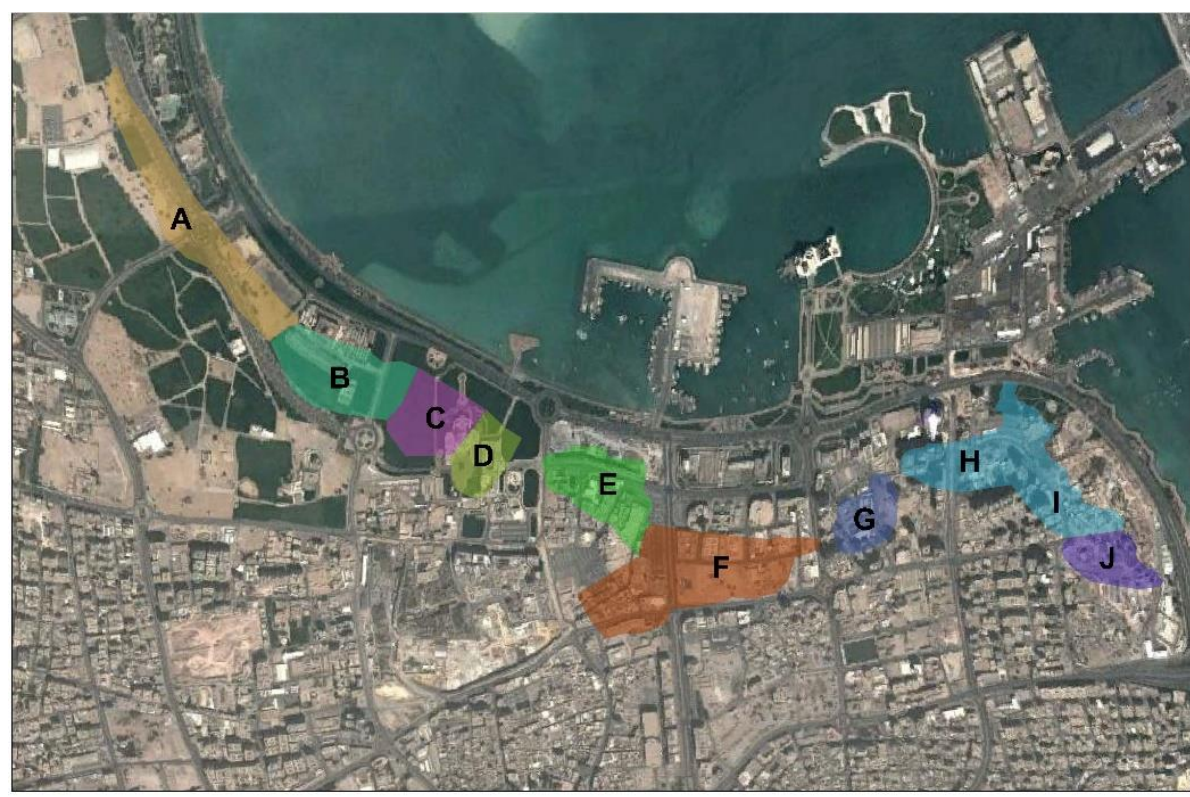

A - Rumailah

B - Al Bida

C - Marqab Al Gharbi

D - Qalat Al Askar

E - Al Duwailah

F - Al Doha

G - Marqab ash Sharqi

$\mathrm{H}$ - Sulutah

I - Sulutah

J - Al bin ‘Ali

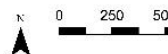

1,000

1.500

2,000 Meters

Figure 5: Districts of the Doha conurbation in 1908, derived from Lorimer's verbal descriptions (Lorimer 1908: 488489) and inferring from later sources and maps. The 'Sulutah' district includes a southern extension that may have once been known as 'Bani Malik', though the term probably only indicated members of the Salata tribe.

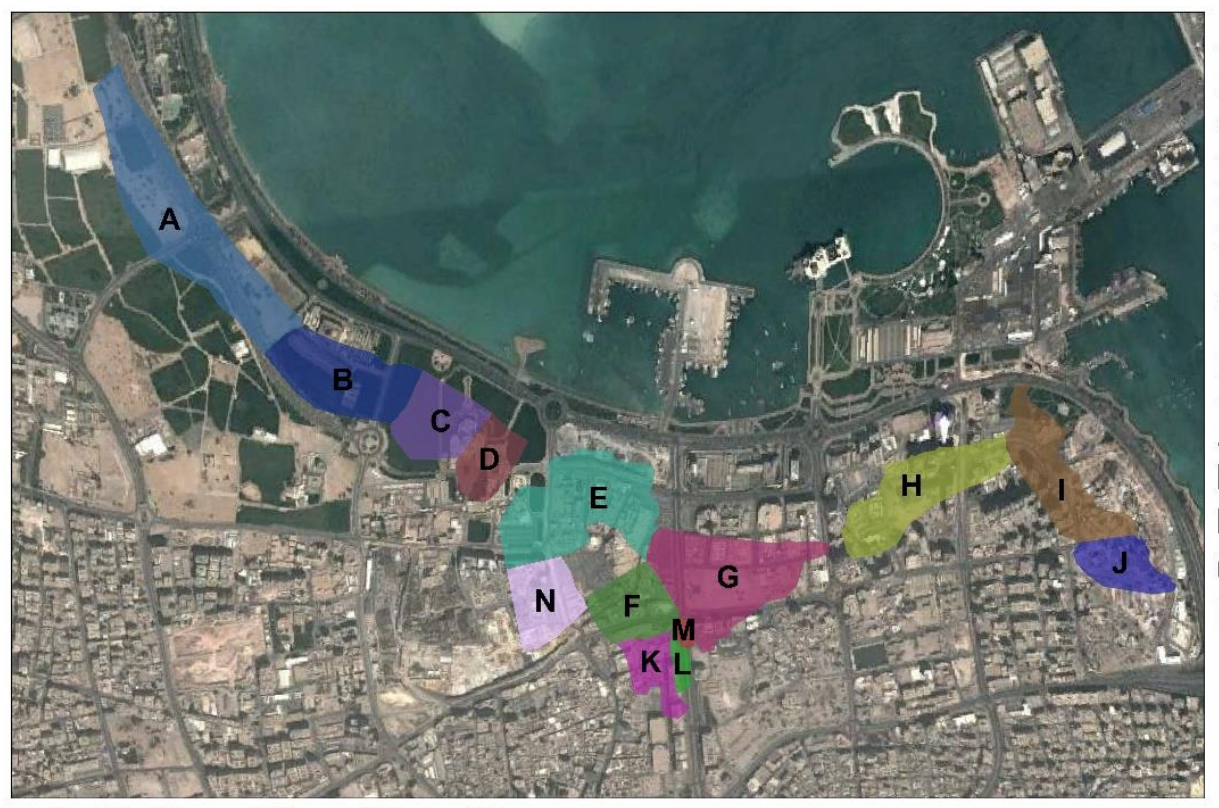

A - Rumeillah

B - Al Bidah

C - Marqab Al Gharbi

D - Qalat Al Askar

E - Al Duwailah

F - Nejd

G - Al Doha

H - Marqab ash Sharqi

I - Salata

J - Al bin 'Ali

$\mathrm{K}$ - Amadahia

$\mathrm{L}$ - Ahmed Bajeis

M - Baharat Al Jufairi

$\mathrm{N}$ - Mohammed bin

Jasim

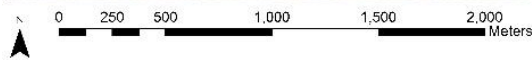

Figure 6: Districts of the Doha conurbation in ca. 1937, derived from a 1937 sketch (IOR/R/15/1/370/344), an RAF aerial photograph of 1937 (IOR/R/15/2/203), Lorimer's verbal earlier descriptions, and archaeological work at the Radwani House in today's Msheireb Heritage District. A district that existed as some barrack-like buildings at this stage later took the name Mohammed bin Jasim. 


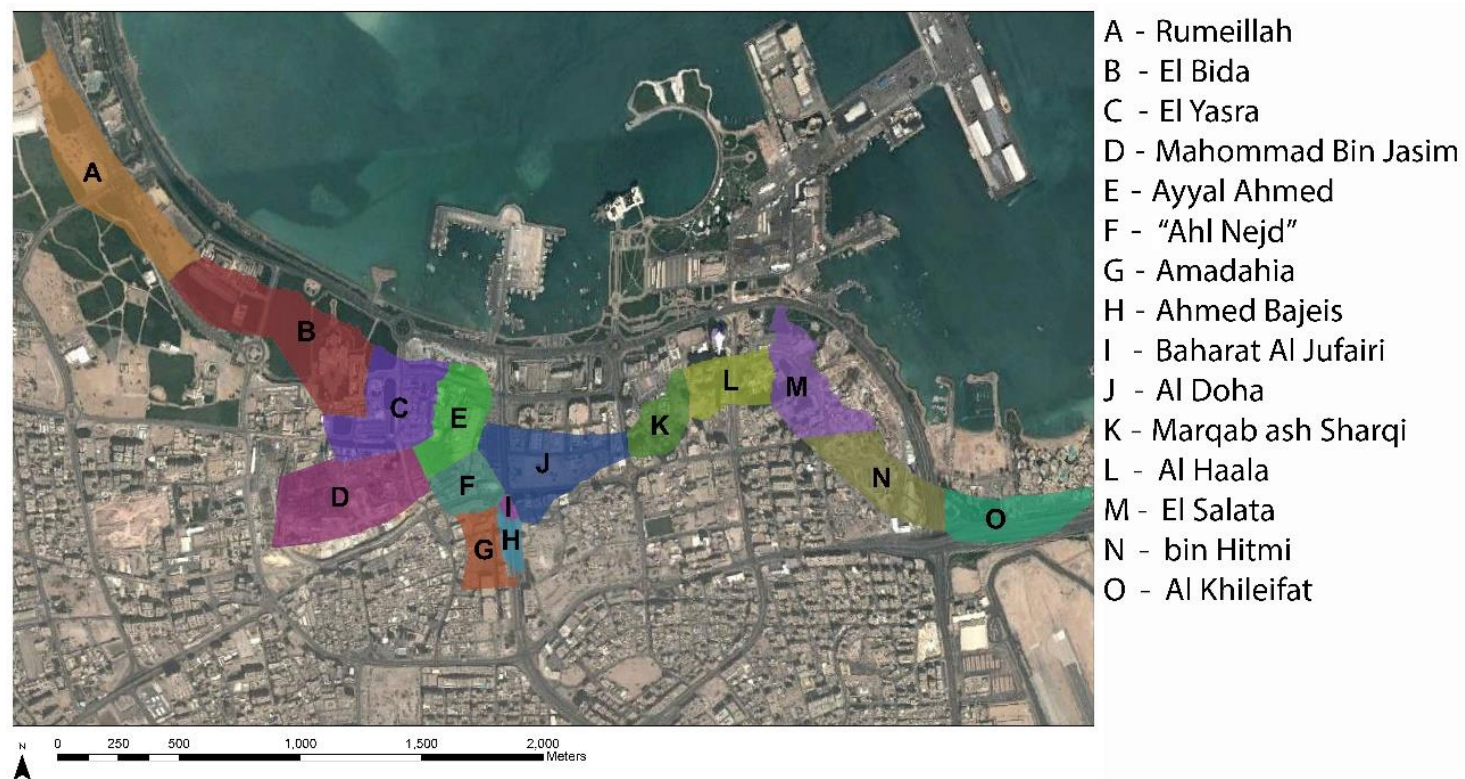

Figure 7: Districts of the Doha conurbation in 1947, derived from aerial imagery of that year, and (for the eastern districts) reading back from the first detailed maps of 1952 by Hunting Survey.

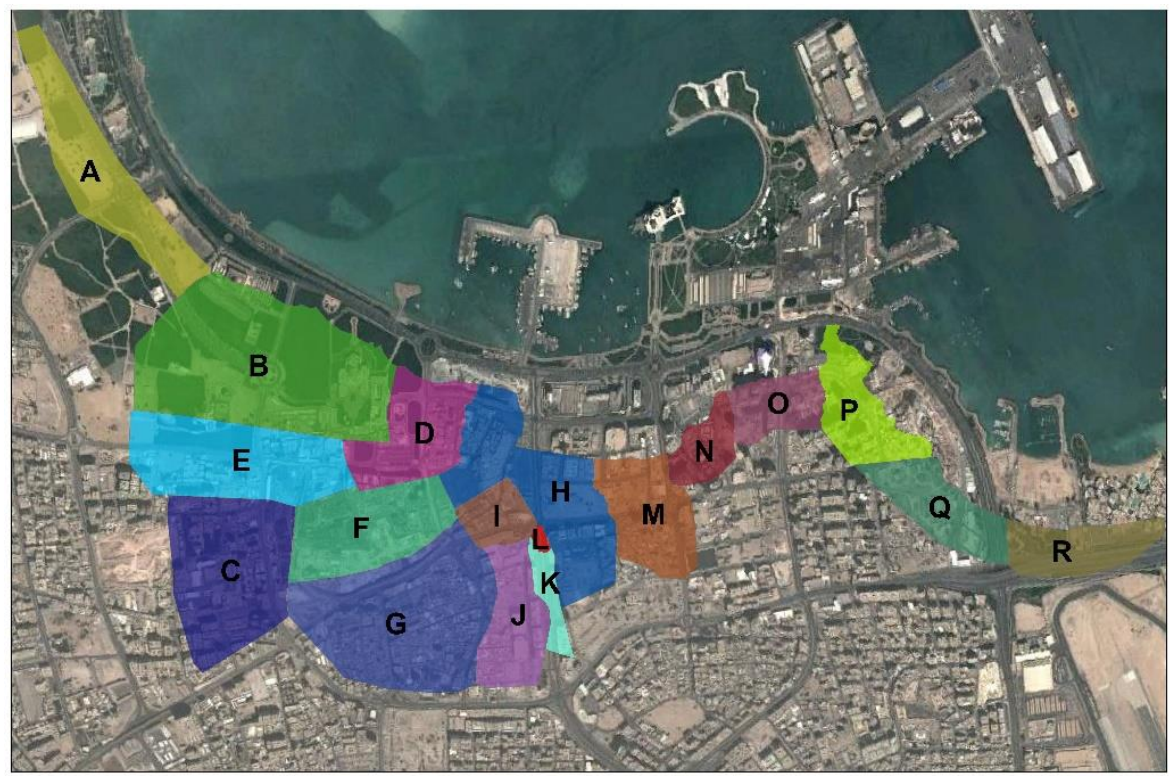

A
A - Rumeillah

B - El Bida

C - El Mesheirib

D - El Yasra

E - Abdeia

F - Mahommad Bin Jasim

G - Najaada

$\mathrm{H}$ - Ayyal Ahmed

I - "Ahl Nejd"

J - Amadahia

$\mathrm{K}$ - Ahmed Bajeis

L - Baharat Al Jufairi

$M$ - El Ghaanim

N - Marqab ash Sharqi

O - Al Haala

P - El Salata

Q - bin Hitmi

R - Al Khileifat

Figure 8: Districts of the Doha conurbation in 1956, derived from maps of 1952 by Hunting Survey. 


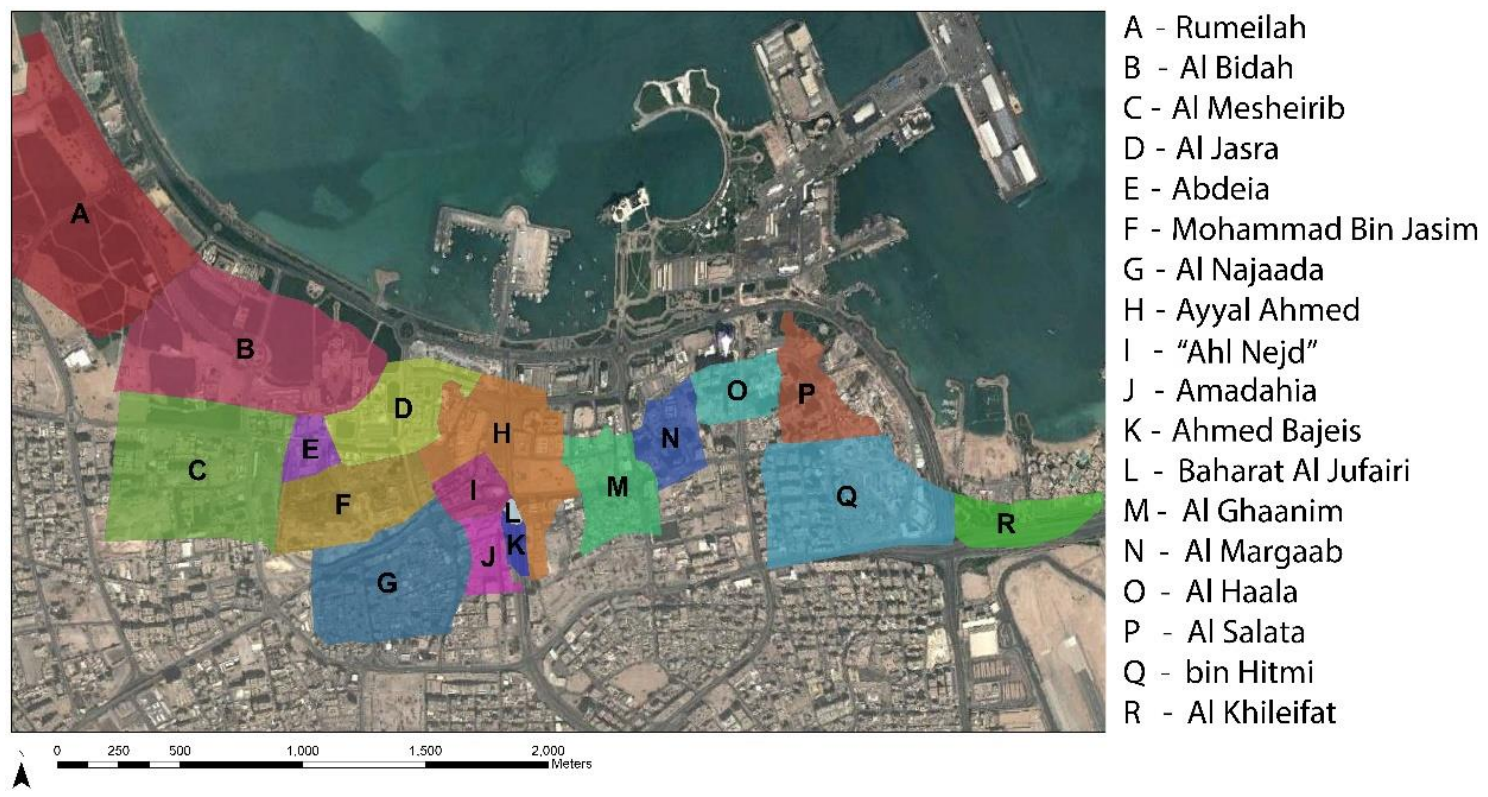

Figure 9: Districts of the Doha conurbation in 1959, derived from maps of 1956 by Hunting Survey.
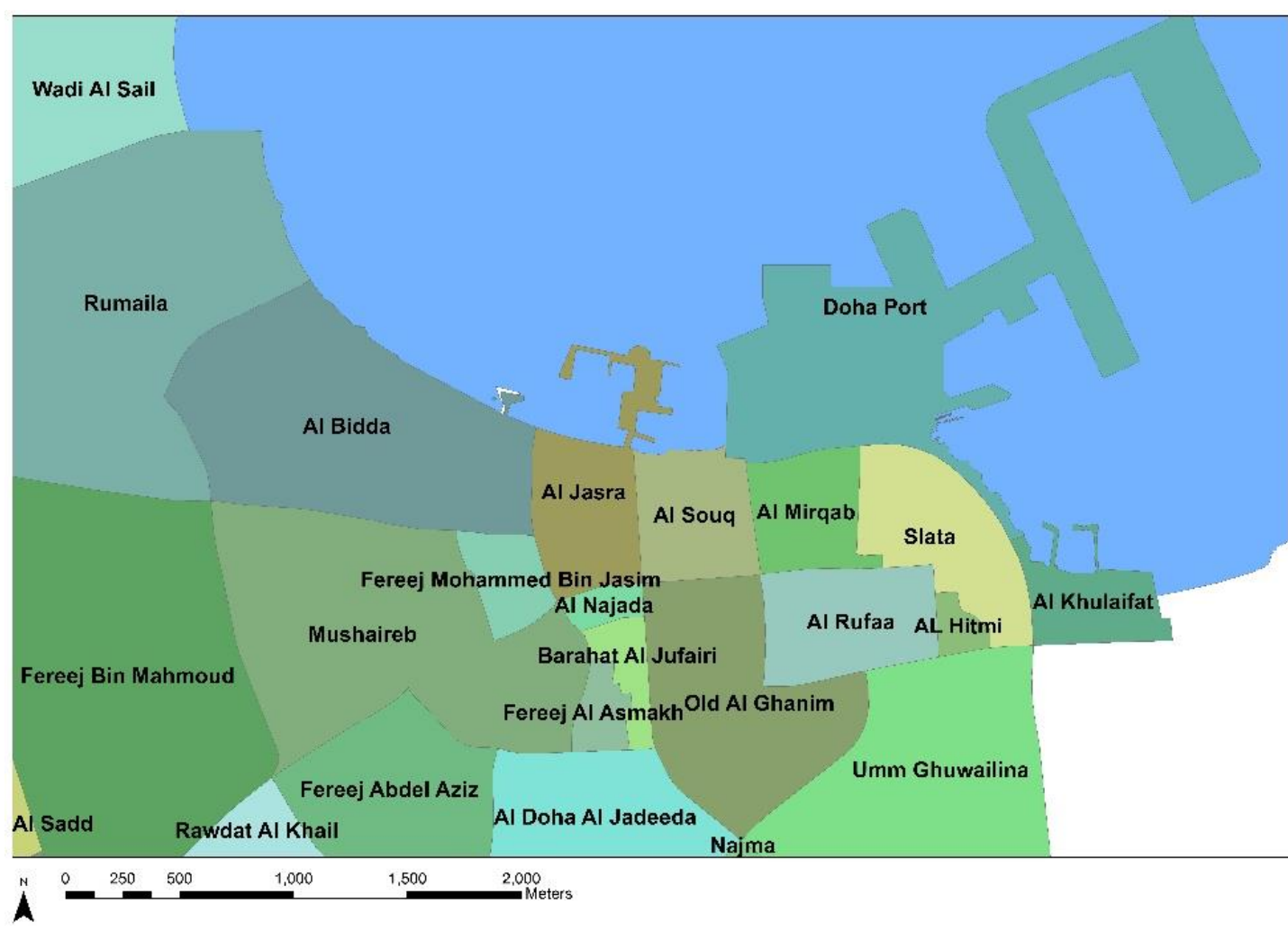

Figure 10: Districts of Doha today (2015), according to the Centre for GIS, Ministry of Municipality and Urban Planning, Qatar. 
The districts mutated through time: some remained fundamentally unchanged while others changed names, moved boundaries, extended, merged, split or were absorbed into other districts ${ }^{6}$. Both Bida' and Doha, for example, began as separate towns but became districts which stayed in their original position. For a while Doha was used simultaneously as the name of the central district (the oldest part of the original town of Doha) and the name of the whole conurbation, but by the mid-20th century the central district (Farij Doha) became divided into Al-Ahmed and Al-Ghanim. Al-Ahmed is known as 'Ayyal Ahmed on the first detailed 1950s maps of the town. The area immediately to the west of the suq, first known as Doha Saghira (Little Doha), became Duwaiha (also meaning Little Doha), and then, some time before the 1950s, Al-Jasra (also Al-Yasra, reflecting local pronunciation). The suq itself seems to have been considered part of Al-Ahmed/Ayyal Ahmed in the mid-20 th century, or perhaps as a separate district in its own right. Some district names are well attested in local memory and appear on the older maps but are not named (most notably Baharna, originally just south of $\mathrm{Al}$ Ahmed), and Al-Asmakh, which is known today but appears to have been considered part of the new district of Najada in the 1950s maps. Many firjān names have disappeared today, their areas having been absorbed into other districts or had their names replaced: Al Bin Ali (became Hitmi), Ahl Al-Nejd was apparently subsumed into Najada and Barahat Al-Jufairi, Amadahia and Ahmed Bajeis were both also seemingly subsumed into Jufairi, Abdeia was subsumed into Msheireb, Al-Hala was subsumed into Mirqab, Marqab Al-Gharbi was subsumed into Jasra and Qalat Al-Askar ceased to be considered a farij and now occupied solely by the Amiri Diwan.

The firjān were considered to have been particularly associated with kinship groups which often gave the districts their name, i.e. tribes, or groups related by blood or geographical origin (Graham, 1978; Nagy, 1997). This is further discussed below (Sections 2 and 3).

\section{Historical Demography and Population Growth}

The rapid expansion of the town between 1860 and 1908 (which we place largely in the 1890s and early 1900s on archaeological and historical grounds) was naturally accompanied by significant population growth. This is supported by the population statistics that we have gathered (fig. 11) ${ }^{7}$. In the $19^{\text {th }}$ century,

\footnotetext{
${ }^{6}$ We acknowledge that the district names and boundaries were not only mutable but may have been mistakenly represented by western observers upon which we rely for this analysis, such as Lorimer, and Hunting Survey Ltd. ${ }^{7}$ As well as the numbers cited here, a very high figure of 18,000 was given for 1945 by a doctor who visited Qatar very briefly 18,000 (Dr Steele, Tuson 1991 vol. 6: 612). The number was given for "Doha and its environs", so may include places such as Rayyan or even Wakra. It should certainly be discounted.
} 
reported population estimates were between 4,000 and 6,000 (Brucks, 1985; Constable and Stiffe, 1989; Kurşun, 2002). With the pearling boom of the late $19^{\text {th }}$ and early $20^{\text {th }}$ centuries there was an increase to 12,000 by the time of Lorimer's survey (compiled between ca. 1905 and 1907), and estimates fluctuated between 12,000 and 10,000 between that time and 1950. The rapid increase between 1950 and 1960 is very notable, and continued thereafter. The 1960 figure $(47,000)$ (Qatar Statistics Authority) indicates how Doha was the focal point of the population in Qatar: in 1959 Hay estimated there were up to 30,000 foreigners in Qatar, plus around 20,000 Qataris (Hay 1959: 108).

\section{Population of Doha}

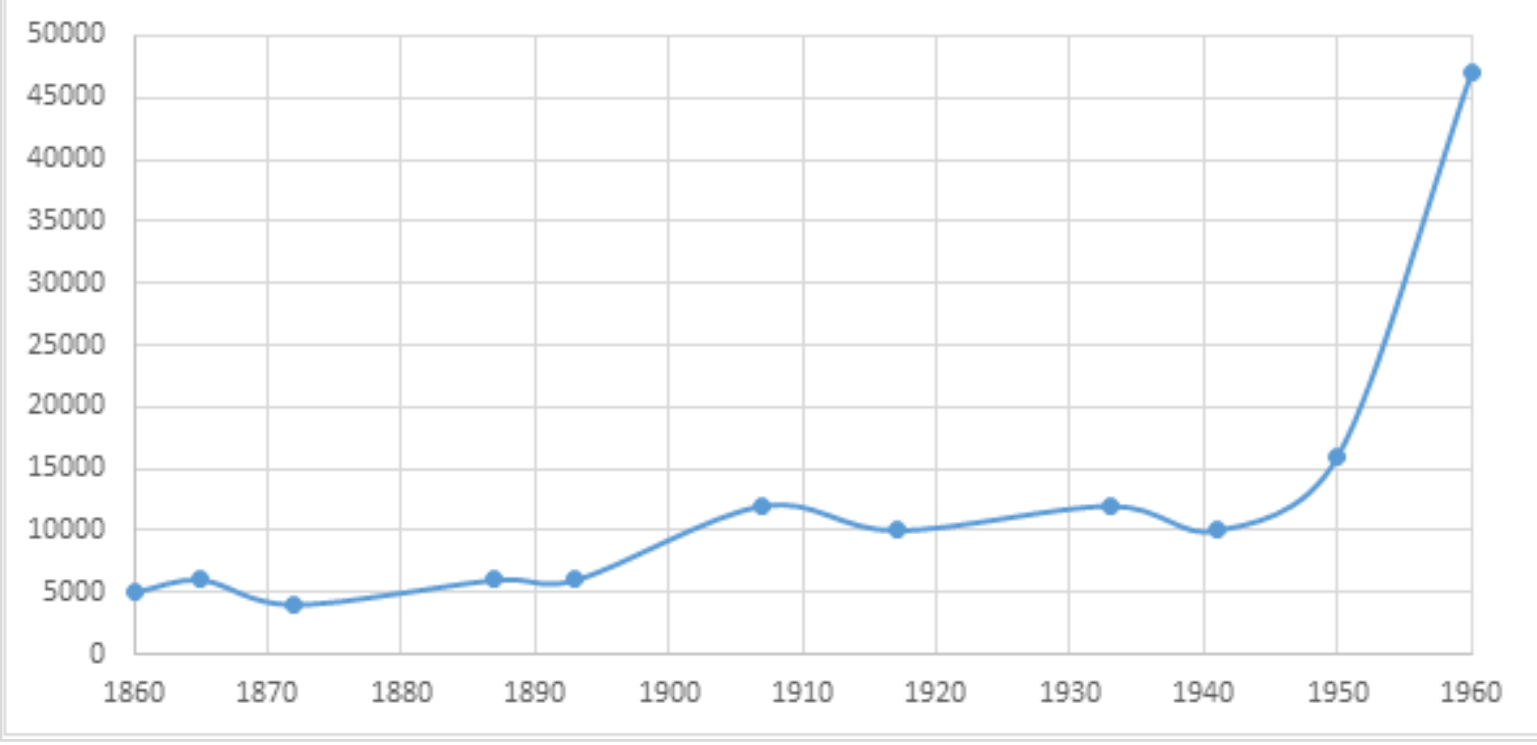

Figure 11: Population estimates 1860-1960. 1860: 5,000 (Constable and Stiffe: 1989 [1864]: 105); 1872: 4,000 (Kurşun 2002: 15-16); 1893: 6,000 (Kurşun 2002: 17); 1907: 12,000 (Lorimer 1908: 489); $1917: 10,000$ (Tuson 1991 vol 5: 355); 1933: 12,000 (Tuson 1991: 701); 1941: 10,000 (letter from W.R. Hay, Tuson 1991 vol. 6: 560); 1945,; 1950: 16,000 (Burdett 1994: 389). 1960: 47,000 (Qatar Statistics Authority).

Before the first detailed statistics became available in the early $20^{\text {th }}$ century (Lorimer 1908) the precise demographic constitution of Doha remains unknown, but can be surmised. British sources from the early to mid- $19^{\text {th }}$ century indicate initial settlement and resettlement of Bida' and Doha by tribal Arab groups, e.g. the Sudan, Al Bu 'Ainain, Al Bin Ali, Musallam, Ma'adhid (including the Al Thani) and others. Other groups would certainly have been present but are absent from historical sources because of the colonial observers' bias towards the most cohesive, powerful and easily-defined groups.

A population increase is likely to have occurred in the 1850 s, not documented statistically but inferred from maps and historical events, when the Ma'adhid (led by the AI Thani family) and their allies relocated from Fuwairit. These new inhabitants certainly supplemented the population of Doha proper, and the appearance of Dowaiha by 1860 indicates expansion into new districts. This probably included arrivals 
from outside Qatar drawn by economic opportunities: by Lorimer's day Dowaiha was associated with Huwalah and Baharnah groups, and was later supplemented by Persian families.

A further expansion is likely to have occurred in the late $19^{\text {th }} \mathrm{c}$, fuelled by the booming pearling industry. This phase of growth is poorly documented, but the names and Lorimer's descriptions of the districts imply that there had been a movement of people from smaller Qatari towns into Doha, along with the arrival of other groups from around the Gulf, and most likely the arrival of immigrants from Nejd. Some but not all of these new districts bore the names of tribal groups or the geographical origins of their inhabitants (Salata, Al Bin Ali/Hitmi, Nejd/Najada) (see also Section 3). Despite its comparatively small size, the detailed population statistics gathered by Lorimer (1908: 489-490) illustrate the demographic complexity of Doha by the early $20^{\text {th }}$ century (Table 1 ).

Table 1: Lorimer's population breakdown of Doha in ca. 1907.

\begin{tabular}{|l|l|}
\hline Population Group & $\begin{array}{l}\text { Number in } \\
\text { Doha }\end{array}$ \\
\hline Al Bin Ali & 1750 \\
\hline Al Bu Kuwari & 100 \\
\hline Amamarah & 100 \\
\hline Bani Yas & 50 \\
\hline Dawasir & 150 \\
\hline Ma'adhid & 500 \\
\hline Manana'ah & 50 \\
\hline Sudan & 400 \\
\hline Sulutah & 3250 \\
\hline Slaves and freed slaves & 3500 \\
\hline Huwalah & 1000 \\
\hline Baqaqalah & 50 \\
\hline Nejdis & 250 \\
\hline Baharnah & 300 \\
\hline Persians & 300 \\
\hline & \\
\hline & \\
\hline & \\
\hline & \\
\hline
\end{tabular}


The highly varied population of ca. 1907 can be broken down as follows 8 :

- Sunni Arab tribal groups, comprising just over half the total population of Doha in 1907. Lorimer listed nine such tribal groups resident in Doha.

- Slaves and former slaves of African descent.

- Non-tribal Sunni Arab families, mainly comprising Huwalah, i.e. Arab families who had resettled in eastern Arabia during the $18^{\text {th }}-20^{\text {th }}$ centuries following centuries of residence on the Persian shore $^{9}$, but also including non-tribal families from the Nejd, and various non-tribal Sunni Arab families who were long-term residents of Doha and Qatari towns.

- Baharnah families i.e. indigenous Shia of eastern Arabia.

- Persian families (also Shia); this portion was to rise significantly in number in the years following World War One.

- Also certainly present but not counted by Lorimer were a few families from tribal groups normally resident in Qatar who only had very small numbers resident in Doha at the time (e.g. the Musallam) and Baluch slaves (probably conflated with African slaves).

- By definition, bedouin groups were not resident in Doha, though some of the settled tribal groups, particularly those which retained bedouin sections elsewhere in Arabia, are likely to have emphasised a real or notional bedouin descent, as they do today (e.g. the Dawasir).

Note that this breakdown is not intended to be reflective of todays' population of Qatari nationals in Doha, which changed during the three decades following Lorimer's survey, and altered again following the advent of oil revenues (see below).

Despite these changes Lorimer's divisions of Qatari society are still recognised by Qatari nationals today, albeit sometimes taking into account subsequent migrations of groups, some of whom were

\footnotetext{
8 These characterizations are based on the individual Gazetteer entries in Lorimer (1908) for each of the various tribes and groups listed by Lorimer in his population statistics for Doha, gathered in 1905-1907.

${ }^{9}$ The Huwalah are generally considered to be non-tribal but the reality is complex. Some groups were certainly regarded as tribal during the 17th and 18th centuries, and many of today's claim tribal heritage "Qatari Hawalat belong to Banikhaled Arab tribes... [and] are pure Arabs and originated from Arab tribes" (Hassan Aljefairi Diary Book 2014, p.41-43). Other local Arabs tend to downplay the Huwalah's tribal heritage, while acknowledging that they once belonged to acknowledged tribes, characterising them as "the descendants of Arab tribes who have returned, in relatively recent times, from the west coast of Iran... These had lost contact with their original tribes and are known as the Hawalah" (Melikian and Al-Easa 1981, 81). In the early 20th century some of Qatar's tribes which are not today characterized as Huwalah were arguably categorized as such, including the Mahandah and the Sulutah (Lorimer 1908). We consider that subjective identity is a constructivist social process, so that selfidentification as being part of a tribe makes a person "tribal" for most analytical purposes, while noting the importance of the specific historical and contemporary contexts of identity construction.
} 
granted citizenship, and always with variations of the "typology" of Qataris dependent on the perspective and demographic origin of the observer. For such typologies, which are usually emic but reported by outsiders, see for example Alshawi and Gardner 2014: 55-56; Cooke 2014: 60-1; Fromherz 2012: 138141 ; Nagy 2006: $128-9$. This is tied in with the issue of Qatari nationality and perceived grades of true Qatariness, and is therefore contested, highly sensitive and not usually discussed in the public domain, though it sometimes spills into publically-accessible social media. There is no space to discuss it further here.

Following Lorimer's survey immigration continued, most notably from the Persian shore. A large number of Persians arrived following the First World War, when their numbers in Qatar rose from 425 to 5,000, with most of the new arrivals settling in Doha (Tuson 1991 vol. 5: 717). This phase of immigration is most strongly indicated by the southwestwards expansion of Jasra (formerly Dowaihah), which can be dated archaeologically to between the 1910 s and 1930 s by excavations at the Radwani House, in the Msheireb Heritage Quarter (Carter \& Eddisford 2013).

It is likely that immigration slowed considerably at the end of the 1920 s as the pearling industry entered its terminal collapse and the global Great Depression struck. The 1933 figure of 12,000 was considered an overestimate at the time, and if we discount Dr Steele's unreliable figure of 16,000 , the population flat-lined between 10,000 and 12,000 between the early 1900s and 1950 (fig. 9). This undoubtedly reflects times of hardship in the 1930s and 1940s, exacerbated by economic problems caused by the Second World War. Most likely the population fell well below the published estimates. According to Crystal "Qataris left for Bahrain, Hasa and other points, depopulating the area by migrating as entire clans: families and retainers" and the population of the entire country dropped from ca. 27,000 (using statistics from Lorimer's survey) to as little as 16,000 or even 10,000 (1990: 117). From this it appears that the population of Doha is likely to have dropped during the 1930s and 1940s (perhaps from 12,000 to 10,000 or below), and emigration was even more severe from the other towns and villages of Qatar. Doha's decline is eloquently demonstrated by the evident abandonment and ruinous state of much of Doha's old town centre, Bida' and Rumeilah in aerial photographs of 1947 and according to John Wilton, the British Political Agent at the end of the 1940s "decades of poverty and, during the War, near famine had led to mass emigration". In his memoirs he claimed that in 1949 "the appearance of the capital, Doha, suggested the aftermath of an air raid as unoccupied and even occupied houses crumbled into decay" (Wilton n.d.). 
As nation-building accelerated following the coming of oil (first shipped in 1950), the groups who had been in place prior to the 1950s were supplemented by a further wave of immigration, of unprecedented scale. In the 1950s and 1960s this comprised most of the inhabitants of the remaining towns and villages of northern Qatar, including several Qatari tribes who already had representatives in Doha and some that did not, as well as returnees who had left Qatar during the 1930s-1940s. Increasingly, the 1960s saw the settlement of bedouin tribes around the outskirts of Doha and in Rayyan (then still considered separate from Doha), chiefly the Bani Hajir, the Ka'aban, the Na'im, and the Murrah. Also notable was a major wave of immigration from outside Qatar, initially including Omanis (particularly Dhofaris), Yemenis, Egyptians, Palestinians, Lebanese and Arab expatriates of other nationalities, soon joined by Pakistanis and Indians. Although a worthy topic of study, and currently a focus of academic debate (e.g. Nagy 2006; Gardner 2011), space precludes a proper discussion of these episodes of immigration here.

The above survey reveals a highly structured historical population with numerous subdivisions according to tribal membership, tribal or non-tribal status, faith, geographical origin, bedouin versus settled, free versus slave, and historical alliance. In theory these consist of largely discrete and endogamous groups, though the reality is more complex. As noted in the previous section and as discussed below (Section 3), some of these population groups were associated with the foundation of certain districts, though in reality no district was likely to have remained homogeneous for long in terms of tribe, ethnicity or faith.

\section{Part II. GIS Analysis of Doha: Urban Layout and the Islamic City}

GIS can be used to model the development of settlements as a purely autonomic phenomenon (Clarke and Gaydos, 1998 ), but we reject the idea that human activity is akin to that of unthinking organisms. Instead we stress the importance of cultural factors according to the popular "Space, Place and Nature" models developed by mainly humanistic geographers (Tuan, 1977). We also reject the assumption of positivist economists that human economic actions are necessarily rational, but we nonetheless believe that GIS analysis of Doha and other Gulf towns can reveal behaviours and patterns arising from the economic, social, political and spiritual lives of their inhabitants. We therefore use GIS to analyse the physical aspects of the town that affect the basic human needs and daily lives of its inhabitants, including movement, visibility, and access to resources such as mosques, food, markets, the sea, fresh 
water and shade. Through the analysis of separate districts and integration of historical and demographic data, familial and tribal relations can be explored. For the later part of our period of interest, digitization also permits a visualisation of the rapid rebuilding, expansion and reorganization of the town in great detail as oil money began to make its impact.

Rather than approaching the GIS analysis as a self-contained exercise we shall use it to test abstract theories about the structure of the "Islamic" or "Arab" town, as well as explore Doha's specific conditions and structure. We will do this by reference not to the original orientalist conceptions of the Arab and Islamic city, but rather to the more recent models developed in the aftermath of Edward Said's (1978) critique of orientalism ${ }^{10}$, in particular as summarized by Raymond $(1994,2008)$. The orientalist school assumed a lack of regularity, regulation and communal activity (apart from religious worship), and viewed the "Arab city" as disorganised, structured wholly around its mosques, and in terminal decline (Marçais, 1957; Tourneau, 1957). In contrast, more recent scholars of urbanism discern a series of structuring principals which are common to the towns of the Arab and Islamic world (Raymond, 2008; Abu-Lughod, 1987; Raymond, 1994). We take as our starting point Raymond's perceptive exposition of characteristics and structuring principles that he finds common to the Islamic City (Raymond 2008: 59-69), which we have arranged into six points:

1. Very marked separation of central zone of economic and administrative activity from residential districts.

2. Compartmentalised or segmentary nature of village-like residential districts.

3. Graduation of activities from the centre, i.e. that activities requiring space (e.g. rope-making, mat-makers, traders in grain or other foodstuffs) or creating nuisance (ovens, slaughterhouses, tanneries) tend to be located on the outskirts; and that the less important the trade the closer to the centre it will be to the periphery (Raymond 2008: 64).

4. Segregational factors and inequality, also graduating from the centre. Raymond (2008: 65-68) noted that high-status dwellings and districts were found close to the centre, medium-status ones were in a band outside these, while the dwellings of the poor ("popular dwelling") were at the outskirts.

5. Segregation by community (faith group, kin group, ethnicity).

\footnotetext{
${ }^{10}$ We note that Hourani was expressing his doubts as early as 1970 Hourani A. 1970. Introduction: The Islamic City in Light of Recent Research. The Islamic City. Oxford: Bruno Cassirer, 9-24..
} 
6. The presence of administrative organisations, not merely of the centre and the central authority, but also those relating to districts, and spread across the city relating to diverse communities and faith groups.

While these features are a useful starting point, they are broad, and some are applicable to almost any city. We have accordingly adapted Raymond's analysis to produce the following list of structuring principles, which we shall use to explore the historical development of Doha, and the characteristics of an Arab and Islamic town in the context of the Gulf:

1. Separation between zones of economic activity and zones of residence.

2. Segmentary arrangement of districts.

3. Compartmentalisation of residence along kinship and community lines. Like Raymond we consider kinship and community to be major structuring principals in the development of the city in the Gulf region, and other regions of the Arabia and Islamic world.

4. Segregational factors and inequality.

5. Central administration. We have retained Raymond's focus on central and distributed administrative bodies, but limited it to the evidence for central administration, which only becomes physically evident in the city after the arrival of oil revenues. Other forms of district or community governance (legal bodies, administration of waqf) remain invisible to us through GIS, though we presume them to exist and will continue historical research on the topic.

6. Patronage. To Raymond's list we add the influence of patronage, not only by the ruling family, but also by sheikhs of other lineages, wealthy merchants and other community leaders, who played a structuring role in the foundation and development of the districts, mosques, charitable foundations and public places of the town.

7. Historical role of defence. Defence was highly significant in the physical development of Doha (and all other Gulf towns), even after it had apparently ceased to be a major consideration: the ring-development of many Gulf towns, most notably Doha and Kuwait City (Nakib 2011), is a direct legacy of the location of its city walls in the pre-oil era

8. Importance of the sea. Equally important is the sea to Doha and the other Gulf towns, as provider of sustenance, both directly (through fishing) and through trade (through the provision of pearling revenues, and as a conduit of maritime trade, which provided the bulk of basic foodstuffs available to the people of Doha).

9. Access to drinking water is vital to survival of the townspeople in an arid environment. 
10. Access to resources and communication through the town is a significant structuring principal.

11. Climate. The effect of climate on the structure of Doha and other towns in the Arab and Islamic world needs to be explored, so we have included this in its own section.

12. Religion and Mosques is a final criterion by which to explore urban life in Doha and any other town with a Muslim population, in everyday life and on special occasions, for example in the location of district mosques, Friday mosques and Eid prayer grounds, and access thereto.

We did not see any evidence for Raymond's point 3, the graduation of activities from the centre, in traditional Doha. This may be because of the particularities of local society, but is equally likely to be due to the small scale of Doha, such that specialised zones of industrial activities were not necessary. Specialised activities were instead concentrated along the shoreline (maintenance of pearling, fishing and trading boats) and dockyard area which adjoined the suq. The absence of Raymond's criterion is worthy of note, but we have left it out of our modified list of criteria on account of having no data to model.

\section{Separation between zones of economic activity and zones of residence.}

This is clearly manifested in Doha by the central suq (now generically known as Suq Waqif, a name which formerly only referred to a part of the central suq district). This brought together most of the town's day-to-day commerce, both in terms of fixed shops and arcades and more impermanent, stalls on the sea-shore and the edges of the suq, as well as an adjoining open space used as a livestock market, where bedouin and visitors from outlying towns and villages congregated to sell their animals. The bedouin also used to sell wood there. The area in 1949 is described by Othman:

The centre of activity in Doha, both commercial and social, was the market place, with its scattered cafés like the popular Abdullah Ghanim cafe, on the site of the present Bismillah Hotel11, which was never short of customers. The main market place was Souk Waqif, which is fast disappearing under the pressure of modern development, though a small section of it remains with its original form and character [in 1980]. Souk Waqif was divided into two parts. One section specialised in fish, the staple diet and trade of the local population. This was situated between the present Bismillah Hotel and the crossroads of Baharna and Najjada

\footnotetext{
11 The Bismillah Hotel was built some time between 1956 and 1959, according to the aerial imagery.
} 
streets. The other section, the general market, stretched from Baharat al Jufairi to the harbour. These two sections were separated by a large open area which served as the camel market. ${ }^{12}$ Here the al-badiyah - people of the desert - would assemble to buy and sell camels, and to trade their typical produce of the Bedouin economy, animal fats, camelhair textile products such as blankets and carpets, and firewood, in exchange for provisions and utensils. The market place provided the link between the two traditional communities of the desert and the sea (Othman 1984: 3-4).

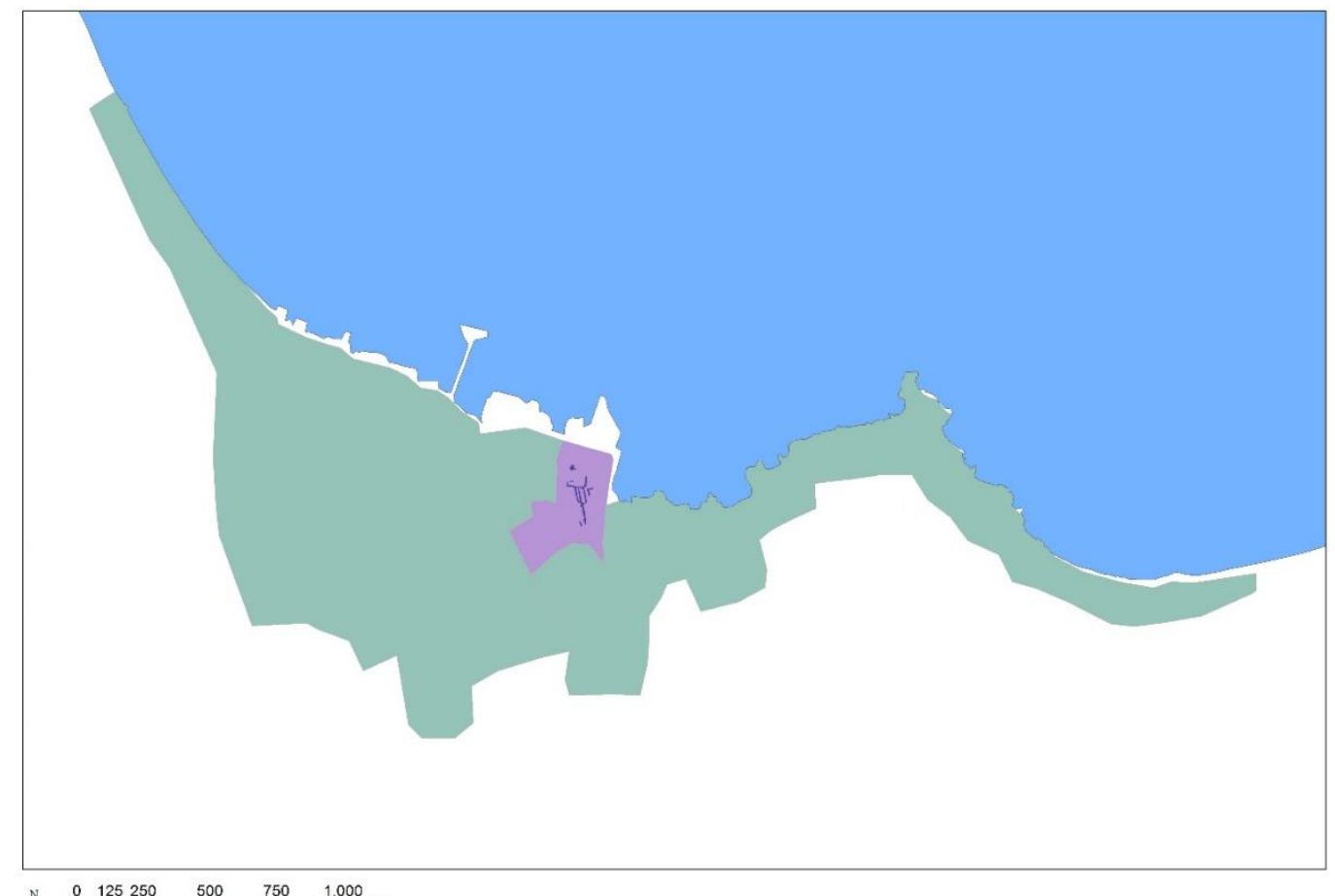

A

Figure 12: Commercial and Residential Separation in 1952. The central suq area is in purple, with covered lanes shown as dark lines.

The central suq zone encompassed areas beyond the well-known covered alleys and waterfront warehouses, including western parts of Al Ahmed, eastern parts of Jasra and the edge of Baharat Al Jufairi. Almost all economic activity took place in this area, and many of the merchants lived nearby in Jasra. It was also literally the centre of town. Central Point analyses of Doha in 1947, 1952 and 1959, which take into account the position of every single building of the town to calculate the most central location ${ }^{13}$, show the suq area squarely in the middle of town, most notably in 1952 (fig. 13).

\footnotetext{
12 Ibrahim Jaidah adds that cattle would be brought to Doha by the villagers at the weekend; some of these visitors used to stay at the Obeidan house (interview with Ibrahim Jaidah, conducted by Hamad Almuhannadi, 28 March 2013).

${ }^{13}$ ArcGIS defines Central Point as: "The Central Feature tool identifies the most centrally located feature .... Distances from each feature centroid to every other feature centroid in the dataset are calculated and summed. Then the feature associated with the shortest accumulative distance to all other features ... is selected and copied to a newly created output feature class".
} 
In 1947 the Central Point had been ca. $200 \mathrm{~m}$ to the southeast of the southern tip of the covered suq, and by 1959 the mathematical centre of town had moved to ca. $200 \mathrm{~m}$ south of the southern tip. These minor movements can be explained by the new development that took place between 1947 and 1952, namely the expansion of Msheireb, which pulled the centre of gravity to the west; and by 1959, a pull to the south caused the ring of new development to the south of the old town (particularly Farij Abdel Aziz and Dohat al-Jadid - New Doha - both now between B Ring Road and what used to be the A Ring Road).


Figure 13: 1959 map of Doha showing location of Doha’s Central Point in 1947, 1952 and 1959.

\section{Segmentary arrangement of districts.}

The quarters or districts of Doha (referred to locally as firjan, s. farīj) are, to varying degrees, physically self-contained from the point of view of (in)accessibility and separation from neighbouring districts, as well as socially self-contained, particularly in terms of the provision of mosques and public spaces but also because of the restrictions on accessibility mentioned above. To an extent, therefore, Doha can be regarded as a modular arrangement of districts rather than a single organically integrated unit. 


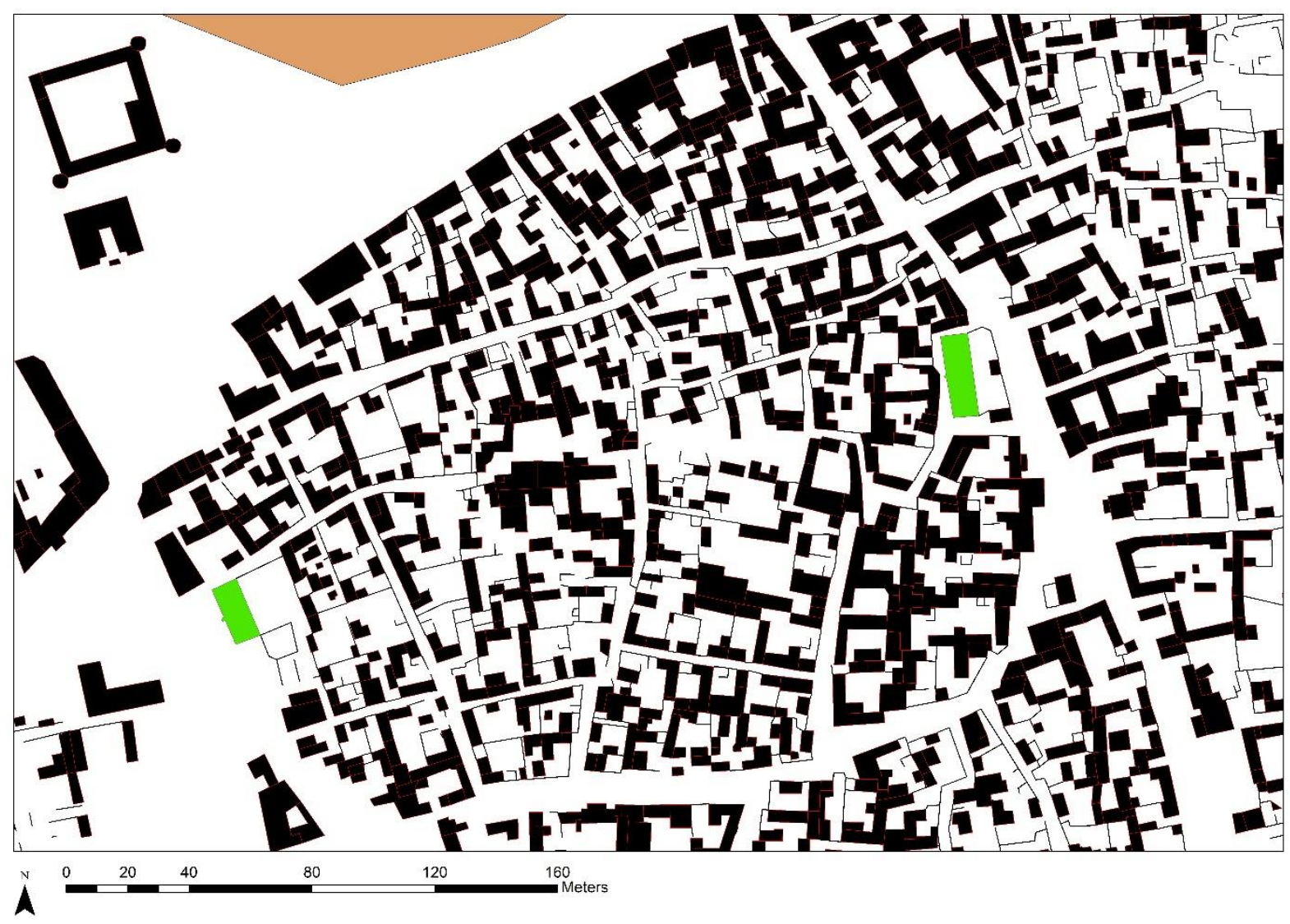

Figure 14: 1952 map of Doha showing the district known as "Ahl Nejd".

This compartmentalisation is quite evident in the plan of the town (fig. 14). As noted below (Section 3) this a reflection of the socially compartmentalized nature Doha's demographics, and the sequential manner in which the districts were founded by incoming population groups. The GIS analysis of communications indicates that that each district has an inner area of low-access of variable size and intensity, implying that each maintained its own structure of containment which contributed to the community solidarity (al-asabiyyah) and closeness (al-qarabah) of its inhabitants (see below).

This can clearly be shown in (fig. 15), which shows a hot/cold map of accessibility. It reveals that each farij can be seen to have an individual area of low access, particularly noticeable in Ahl Al-Nejd, Jasra, and the eastern districts. This reflects their self-contained stucture and the segmentary nature of the town, as described by Raymond (2008: 63), whereby the districts acted like villages, opening only to themselves rather then the neighbouring districts, and each having a separate relationship with the central commercial area. 


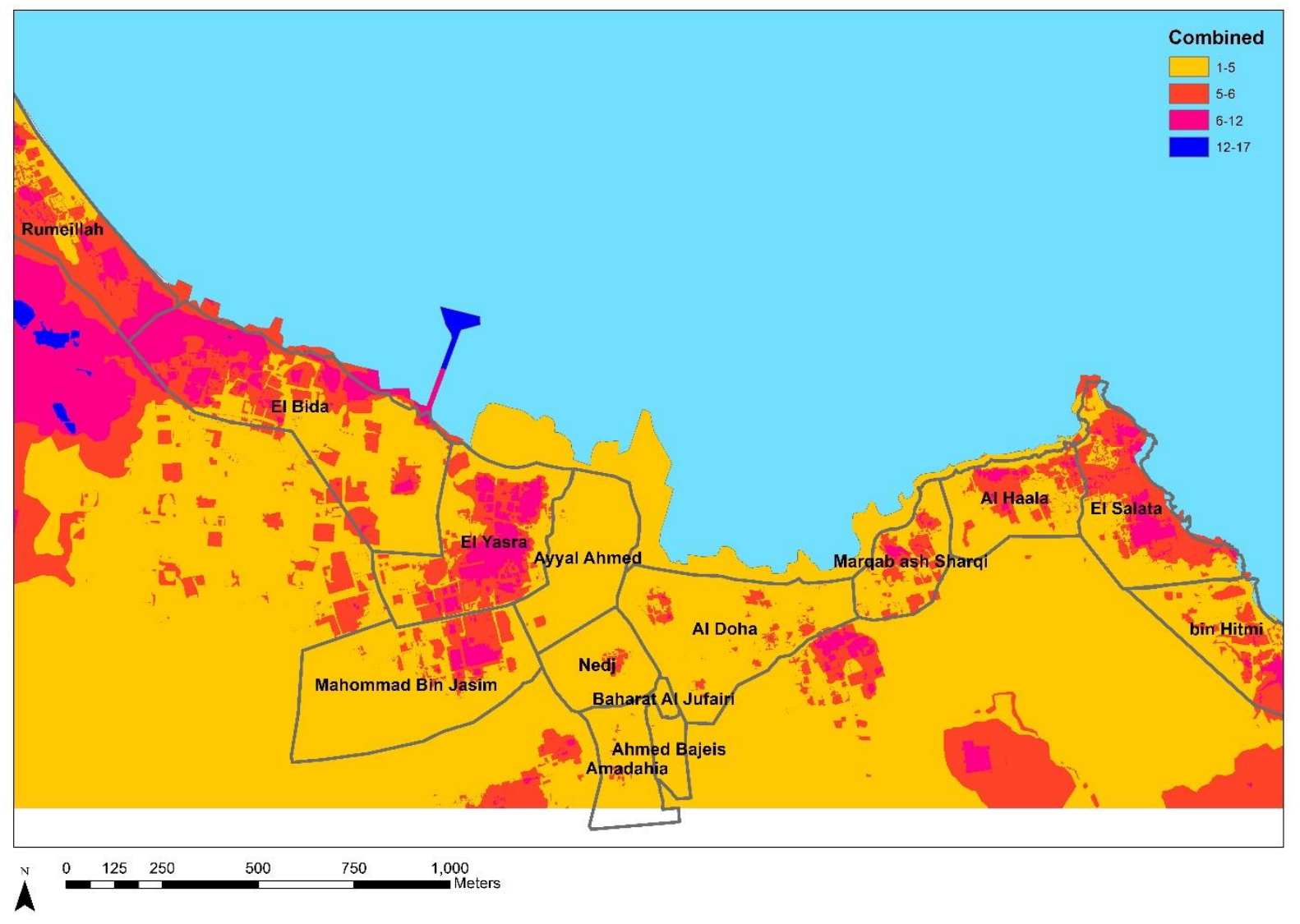

Figure 15: Hot/cold access map of Doha in 1952.

\section{Compartmentalisation of residence along kinship and community lines.}

Connected to the segmentary arrangement of districts is the observation that many were specifically associated with particular population groups, at least in origin. This was sometimes encoded in the name (e.g. Salata being the district of the Suluta tribe, or Najaada being the district of people from the Nejd). In Qatari popular memory, "each tribe used to have their own villages and then, when they moved into Doha, they moved together in their own areas" (Nagy, 2006: 134). The neighbourhoods thus formed were often dense and crowded since al-qarabah (closeness) was perceived by immigrant groups as their guarantee of security and protection (Fuccaro, 2009: 95). Indeed, there remained in the 1990s a nostalgia for this way of living: "family closeness—not only in the nature of relationships but in actual residential proximity — remains a strong cultural ideal for most Qataris" (Nagy, 2006: 127). According to another observer "people in the neighbourhood lived like one large family" (Abu Saud, 1984: 31).

The most obvious associations with specific population groups are found in those districts named after specific tribes or families, but these were actually a minority of districts. An analysis of the names of the old districts shows that less than half (10 of around 26 ) of the districts known from the $19^{\text {th }}$ to the mid- 

geographical characteristics, built features or individuals.

Table 2: Names of Historic Districts of Doha. The 1937 and 1947 names are inferred from the 1937 sketch and 1952 Hunting Survey maps, i.e. if the district can be seen to exist on the aerials of 1937 and 1947, then the name given on the 1952 map is applied. Early 20th century data is derived from Lorimer (1908) and Burchardt (for 1904). Spellings are standardized to those most commonly used locally. Use of the definite article appears to be inconsistent for district names in Doha, but has been retained for those which it appears always to be used (AlGhanim, Al-Asmakh, Al-Ahmed, Al-Hala). Note that we have not included districts which emerged in the 1950s, such as Fareej Abdulaziz, Umm Ghuwailina, Bin Mahmoud and others.

\begin{tabular}{|c|c|c|c|c|c|c|c|c|c|}
\hline & 1823 & 1860 & 1908 (Lorimer) & 1937 & 1947 & 1952 & $\begin{array}{l}1956- \\
1959\end{array}$ & $\begin{array}{l}\text { Present day } \\
\text { or attested } \\
\text { in non-map } \\
\text { sources }\end{array}$ & $\begin{array}{l}\text { Meaning or Significance of } \\
\text { Name }\end{array}$ \\
\hline \multirow{5}{*}{ 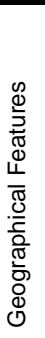 } & Doha & Doha & Doha & Doha & Doha & $\begin{array}{l}\text { Thenceforth } \\
\text { Ghanim ano }\end{array}$ & $\begin{array}{l}\text { divided into } \\
\text { Jejd/Najada }\end{array}$ & Al-Ahmed, Al- & "Bay" \\
\hline & & Doha Saghira & Dowaiha & Dowaiha & \multicolumn{4}{|c|}{ Thenceforth Al Jasra } & "Little Doha" \\
\hline & & & & & & Musheirib & Musheirib & Musheirib & "Small place of water" \\
\hline & & & Rumeilah & Rumeilah & Rumeilah & Rumeilah & Rumeilah & Rumeilah & "Small place of sand" \\
\hline & & & & Al-Haala & Al-Haala & Al-Haala & Al-Haala & & "Reef" \\
\hline \multirow{9}{*}{ 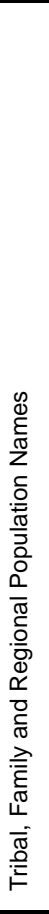 } & & & & & Kholaifat & Kholaifat & Kholaifat & Kholaifat & Tribal name (Al Kholaifi) \\
\hline & & & Al Bin Ali & Al Bin Ali & \multicolumn{4}{|c|}{ Thenceforth Hitmi/Bin Hitmi } & Tribal name (Al Bin Ali) \\
\hline & & & & & Bin Hitmi & Bin Hitmi & Bin Hitmi & Hitmi & $\begin{array}{l}\text { Family name (a leading } \\
\text { family of the Al Bin Ali) }\end{array}$ \\
\hline & & & Salata & Salata & Salata & Salata & Salata & Salata & Tribal name (AI Suluta) \\
\hline & & & & & & $\begin{array}{l}\text { Ayyal } \\
\text { Ahmed }\end{array}$ & $\begin{array}{l}\text { Ayyal } \\
\text { Ahmed }\end{array}$ & Al-Ahmed & $\begin{array}{l}\text { Family name - Al Ahmed } \\
\text { branch of AI Thani }\end{array}$ \\
\hline & & & & & & Al-Ghanim & $\begin{array}{l}\text { Al- } \\
\text { Ghanim }\end{array}$ & Al-Ghanim & $\begin{array}{l}\text { Family name (a leading } \\
\text { family of the Al Bin Ali) }\end{array}$ \\
\hline & & & & & & Ahl al-Nejd & $\begin{array}{ll}\text { Ahl al- } & \\
\text { Nejd }\end{array}$ & & $\begin{array}{l}\text { Named after people from } \\
\text { Nejd }\end{array}$ \\
\hline & & & & & & & Najada & Najada & $\begin{array}{l}\text { Named after people from } \\
\text { Nejd }\end{array}$ \\
\hline & & & & & & & & Baharna & $\begin{array}{l}\text { Named after the baharna, } \\
\text { Shia inhabitants of Bahrain } \\
\text { and Eastern province }\end{array}$ \\
\hline \multirow[b]{3}{*}{ 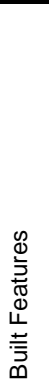 } & & & $\begin{array}{ll}\text { Marqab } & \text { Al- } \\
\text { Gharbi }\end{array}$ & $\begin{array}{l}\text { Marqab } \\
\text { Al-Gharbi }\end{array}$ & & & & & $\begin{array}{l}\text { Built feature ("western } \\
\text { watchtower") }\end{array}$ \\
\hline & & & Qalat Al Askar & $\begin{array}{l}\text { Qalat Al } \\
\text { Askar }\end{array}$ & & & & & Built feature ("soldier's fort") \\
\hline & & & $\begin{array}{l}\text { Marqab ash- } \\
\text { Sharqi }\end{array}$ & $\begin{array}{l}\text { Marqab } \\
\text { ash- } \\
\text { Sharqi }\end{array}$ & $\begin{array}{l}\text { Marqab } \\
\text { ash-Sharqi }\end{array}$ & $\begin{array}{l}\text { Marqab } \\
\text { ash-Sharqi }\end{array}$ & Marqab & Marqab & $\begin{array}{l}\text { Built feature ("eastern } \\
\text { watchtower") }\end{array}$ \\
\hline \multirow{2}{*}{$\begin{array}{l}\frac{8}{5} \\
\text { s } \\
\text { ch }\end{array}$} & Bida' & Bida' & Bida' & Bida' & Bida' & Bida' & Bida & Bida' & Unknown (lit. "innovations") \\
\hline & & & & & Amadahia & Amadahia & Amadahia & & Meaning unknown \\
\hline
\end{tabular}




\begin{tabular}{|c|c|c|c|c|c|c|}
\hline & \multicolumn{2}{|l|}{ (formerly Doha Saghira/Dowaiha) } & \multirow{2}{*}{\begin{tabular}{|l} 
Jasra \\
Abdeia
\end{tabular}} & \multirow{2}{*}{$\begin{array}{l}\text { Jasra } \\
\text { Abdeia }\end{array}$} & \multirow[t]{2}{*}{ Jasra } & \multirow{2}{*}{$\begin{array}{l}\text { Meaning unknown. Also } \\
\text { Yasra in local pronunciation } \\
\text { Meaning unknown }\end{array}$} \\
\hline & & & & & & \\
\hline & & $\begin{array}{l}\text { Ahmed } \\
\text { Bajeis }\end{array}$ & $\begin{array}{l}\text { Ahmed } \\
\text { Bajeis }\end{array}$ & $\begin{array}{l}\text { Ahmed } \\
\text { Bajeis }\end{array}$ & & $\begin{array}{l}\text { Meaning unknown (perhaps } \\
\text { an individual) }\end{array}$ \\
\hline & & & & & Al-Asmakh & $\begin{array}{l}\text { Individual name of major } \\
\text { house owner }\end{array}$ \\
\hline & & & & $\begin{array}{l}\text { Barahat } \\
\text { Al-Jufairi }\end{array}$ & & $\begin{array}{l}\text { Individual or family } \\
\text { associated with a public } \\
\text { open space (baraha) }\end{array}$ \\
\hline 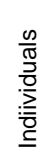 & & $\begin{array}{l}\text { Mhd. bin } \\
\text { Jasim }\end{array}$ & $\begin{array}{l}\text { Mhd. bin } \\
\text { Jasim }\end{array}$ & $\begin{array}{l}\text { Mhd. bin } \\
\text { Jasim }\end{array}$ & $\begin{array}{l}\text { Mhd. bin } \\
\text { Jasim }\end{array}$ & $\begin{array}{l}\text { Individual name of major } \\
\text { house owner (Mohammed } \\
\text { bin Jassim Al-Thani) }\end{array}$ \\
\hline
\end{tabular}

Moreover, it is historically evident that new districts became increasingly heterogeneous as time went on; thus, the two oldest districts in the early $20^{\text {th }}$ century, Bida' and Doha', were also the most demographically diverse, each with seven population groups listed as the main inhabitants (Lorimer 1908: 488-9). This tendency for population homogeneity to be broken down by the intrusion of outsiders is still lamented today, while much nostalgia for the past focuses around an idealised time when families lived surrounded only by kith and kin:

We all knew each other, back then. It was mostly people from the same family, my uncles, cousins, brothers. So, the children were free to run about and the women could pass easily from house to house (Nagy 2006: 126).

We therefore conclude that although compartmentalization was a strong structuring factor and division by population group was idealized, this was progressively diluted and not overwhelming in the long term. We also note that this aspect is not demonstrated any specific GIS output, but rather it is reflected in the segmentary arrangement of districts outlined in Section 2, and is also encoded in the district and mosque names given in Section 12.

\section{Segregational factors and inequality.}

We found it difficult to identify architectural or spatial criteria that might indicate richer or poorer neighbourhoods in the traditional town and in the 1950s town (see also Section 6 below, for the significance of concentrations of palm-leaf housing within the predominantly stone-built town, which does not appear to be a signifier of separation by wealth). One possible indicator is housing density. 
High density housing was characteristic of central Doha and the coast up to Salata, and particularly the Nejd/Najaada district (fig. 14). Further comparative GIS and historical work may reveal whether this is because of wealth disparities at the time that the district was constructed, or the result of cultural and architectural preferences on the part of the builders (i.e. Nejdi conceptions of space may have allowed for denser habitation than those typical of the Gulf coast).



Figure 16: Density of housing in 1952.

We also examined ease of movement and access to the centre and to key resources (see below, Section 10 for full details), in order to test whether some districts were more conveniently located, and therefore potentially more likely to house wealthier inhabitants. In fig. 17 we see that the oldest parts of central Doha were well located in terms of access and communication in the early 1950 s, despite having comparatively dense housing. Both in terms of having greater amounts of space and in terms of access to key areas and resources, however, Jasra would appear to be an excellent place to live. We also note that as well as being adjacent to the suq, where many of the residents of Jasra worked, after 1915 Jasra was in immediate physical proximity to the Amiri residence, which before that had been the site of the Turkish outpost. We note the outskirts of Doha were not conveniently located vis a vis the centre of power and commerce, but neither were they particularly densely inhabited or clearly showing outward signs of poverty. In reality, although disparities in wealth certainly existed in Doha it is hard to discern 
whether this was zoned using GIS analyis of the urban plan, and other techniques may be better suited to this task.

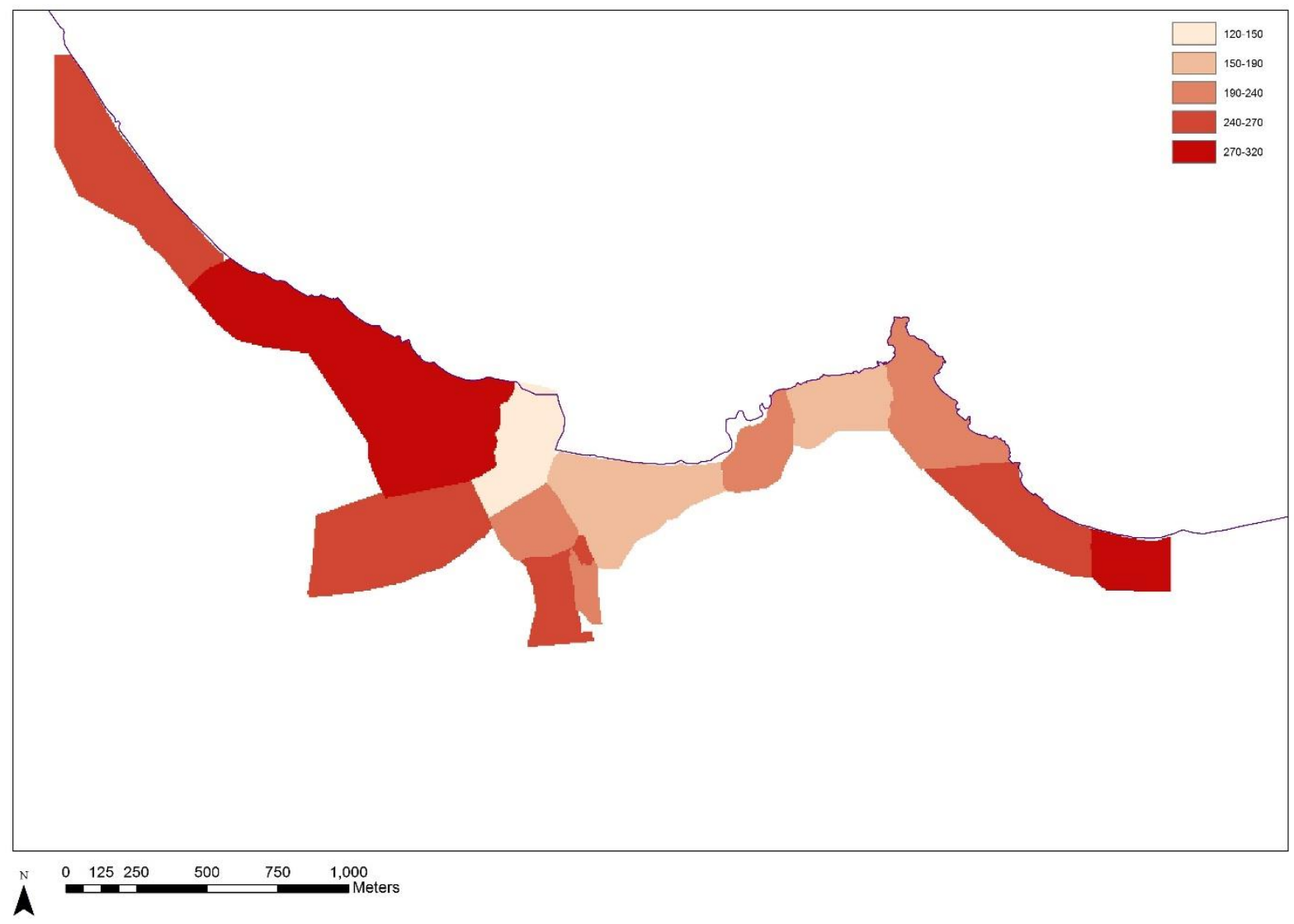

Figure 17: Combined communication and accessibility to resources in 1952, by district. The lighter colours indicate better access, i.e. better places to live according to these criteria.

\section{Central administration}

The village [Doha in 1949] had developed by a natural process without any thought for such modern ideas as town planning (Othman 1984: 1).

The $19^{\text {th }}$ and early $20^{\text {th }} \mathrm{C}$. spread of the town along the shore appears to have been a gradual and spontaneous process, as noted in the quote by Othman, a Qatari resident of Doha. Central administration appears to have been a very weak structuring principal at that time, with both the Amiri authorities and British administration (which still had no permanent presence in Qatar) apparently being content to allow the town to develop unplanned (albeit subject to the forces of patronage noted below).

During the late 1940s and 1950s, however, the British authorities invested increasing efforts in developing the infrastructure of Qatar and managing its burgeoning oil revenues, eventually planting their own Political Agent and an Advisor to the Sheikh in Doha (Hay 1959: 109-112). In this section we 
shall look at the first impact of these policies. Our GIS study provided several new insights into how Doha, a small and entirely traditional Arab and Islamic town, responded to the influx of oil revenues and the enforced rapid development of its central administrative organs. The first direct oil revenues (from 1950) had an immediate effect, and within three years Doha's town plan had begun to change, with the appearance of tarmacked roads, and the construction of new planned districts. By 1959 the new districts extended inland from the historic town, including Al Rufaa, Umm Ghuwailina, Farīj Abdel Aziz, Farīj Bin Mahmoud, plus the southern extension of what is now called Old Al Ghanim (fig. 18).
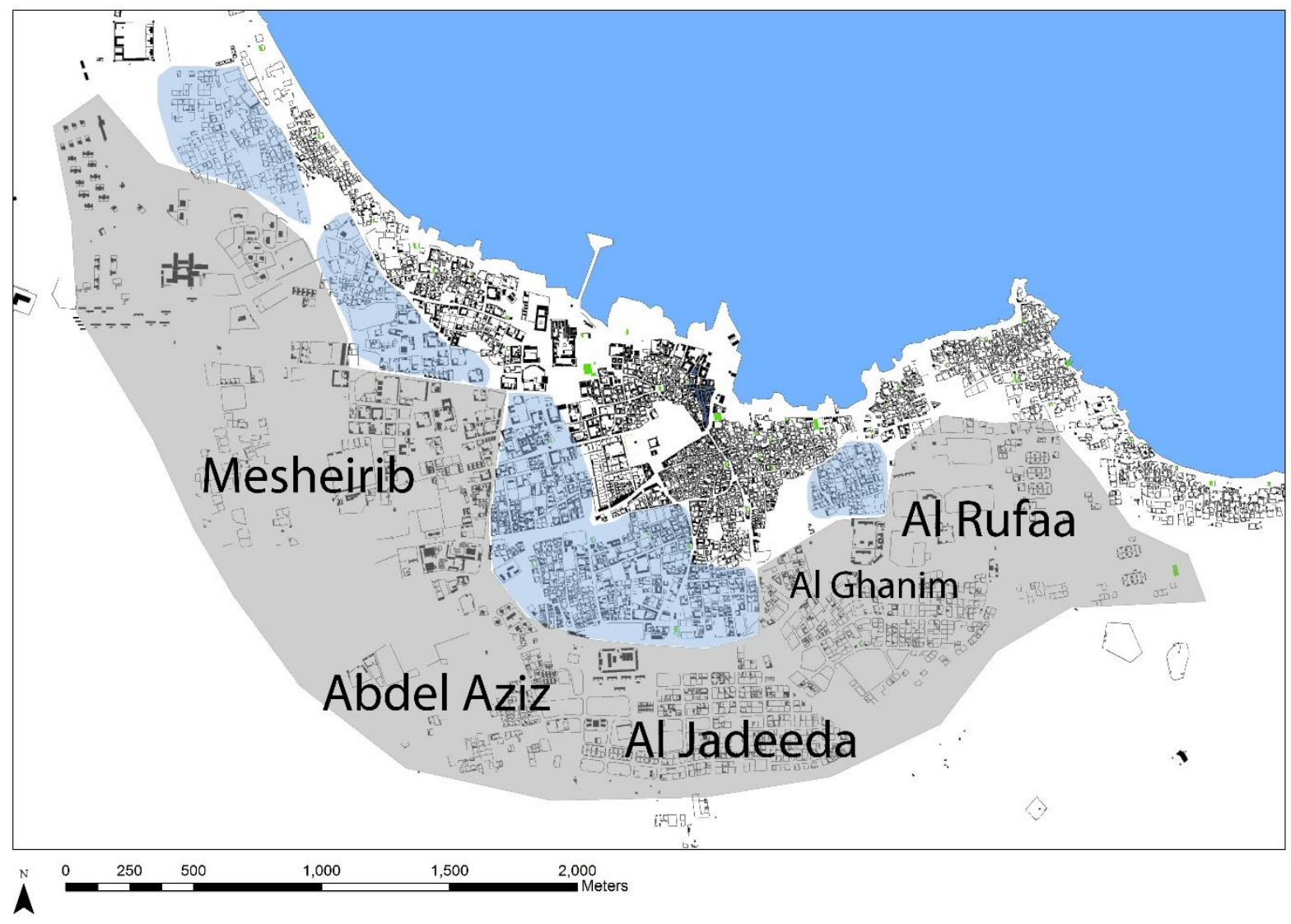

Figure 18: New planned districts in 1959 (Msheireb, Farij Abdel Aziz, Dohat Al-Jadida, Al Ghanim and Al-Rifa'a). Note that some new unplanned districts also sprang up between 1947 and 1959, shown in blue, e.g. Najada and parts of Msheireb, Rumeilah. and AI Ghanim.

It has been wrongly assumed that since the first official housing policy was only established in 1964 and the first urban planners were consulted in the 1960s (Llewelyn-Davies, Weeks, Forester-Walker, and Bor, first documented in 1963), that housing before that date was neither planned nor provided by the state, apart from ad hoc assistance "granted on the basis of personal requests made to the ruler, other members of the ruling family, or influential members of Qatari society” (Nagy, 1997: 105, 227). In reality, the outlines of planned housing on a grid pattern can be seen laid out in Doha al-Jadeeda as early as 1953 , and several new suburbs were already well developed by 1956 . The first clear evidence for planning these residential districts comes from 1950 when, with the new oil revenues increasing 
income in Qatar, a budget was proposed by the newly installed Political Officer in Doha. This budget provided 1.45 lakhs of rupees (Rs 145,000 , then ca. £11,000) for housing, from a total budget of 70 lakhs. By 1953 the budget had increased to 4 lakhs (Rs 400,000) from total expenditure of 86 lakhs and in 1958 it was proposed that Qatar have a Ministry for Public Works responsible for housing and infrastructure development (Tuson, 1991: v.7, 91, 259, 486). Thus, in just the first few years of oil revenue and state budgets, spending on housing went from $2.1 \%$ to $4.65 \%$ of income. This does not include infrastructure spending on roads, utilities and services which saw equally large and steady growth through the 1950s.

The designers and planners of this housing are at present unknown, and we have been unsuccessful in our attempts to locate surviving examples of this first wave of Qatari social housing. The frequent references to Abdullah Darwish in the British records, his political connections, his family's construction and trading interests and his patronage and sponsorship of Lebanese and Syrian architects, builders and professionals strongly suggest that at least in the 1950s most construction took place under his direction (Tuson, 1991: v.7). The new districts themselves took the form of grids of rectangular blocks of housing, each block measuring $100 \times 50 \mathrm{~m}$, with each containing eight square family compounds two of which were sometimes knocked into one. The $100 \times 50 \mathrm{~m}$ blocks still determine the street pattern of these districts of Doha today. The family compounds bore similarities to traditional architecture in that they shared party walls, and the buildings therein tended to be arranged around the outside of the compound creating a courtyard. It is likely that these were built of locally made concrete blocks, which had been in supply at least since 1953 (Moorehead 1977: 96-7), but this is not proven and may not have been universal. 


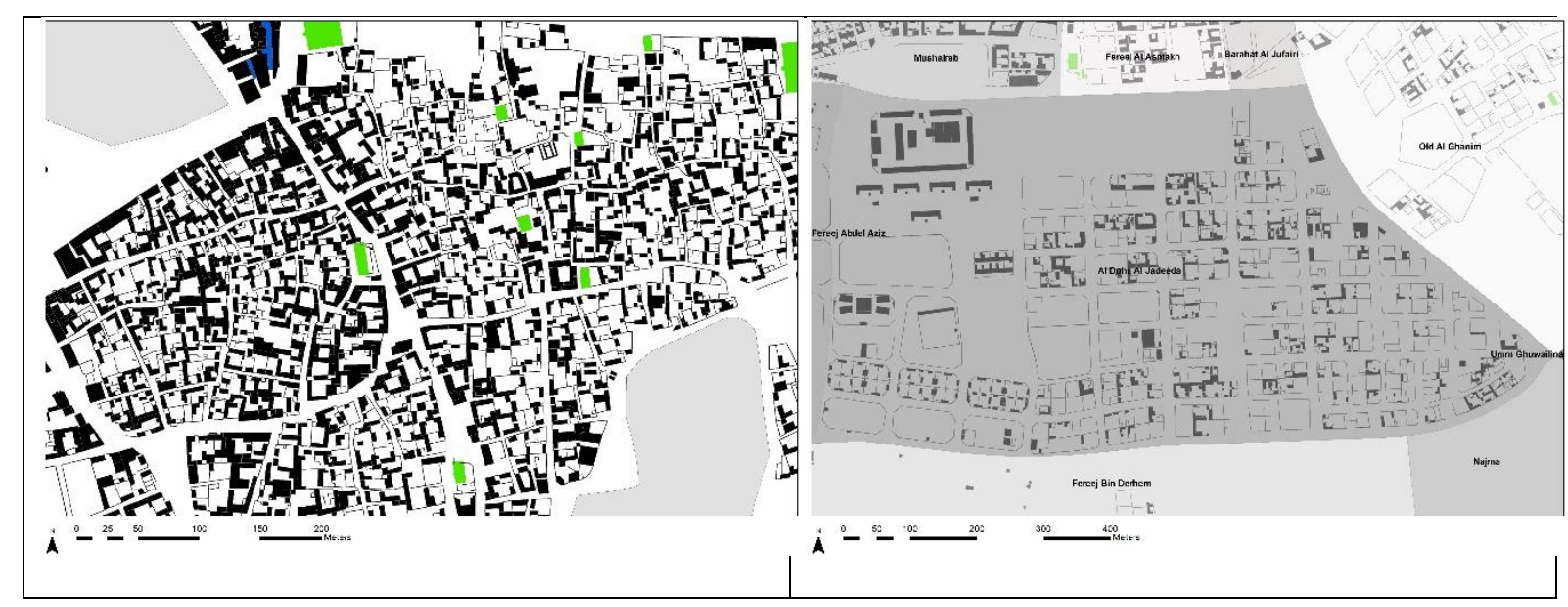

Figure 19: Doha al-Jadeeda in 1959, contrasted with the layout of the traditional firjan of central Doha. Aerial imagery indicates that work on Doha al-Jadeeda had begun in 1953.

Notwithstanding the broad resemblance to traditional architecture, the arrangement of the buildings inside each compound is highly heterogenous. This suggests that the government had provided the plot of land and utilities (perhaps no more than roads and compound walls initially - we doubt that these suburbs were provided with water and electricity from the outset), and perhaps also building materials or a grant with which to purchase them, but that the new owners were at liberty to build or choose the design of their new properties themselves. Alternatively, subcontractors or independent developers may have bought blocks or compounds from the Government (or from Darwish - the two were not easily separated at this time) to develop and sell on to private owners. According to Nagy (1998: 290-292), the houses built by the government after the instigation of the 1964 official housing policy were not traditional in form and not well suited to Qatari society, for example having the house in the centre of the yard so that the provision of a majlis was difficult. It seems that government policy ten years earlier had produced housing more aligned to Qatari needs: the 1950s compound style housing was evidently designed for family, extended family and clan/tribal groupings, and retained traditional building design. 


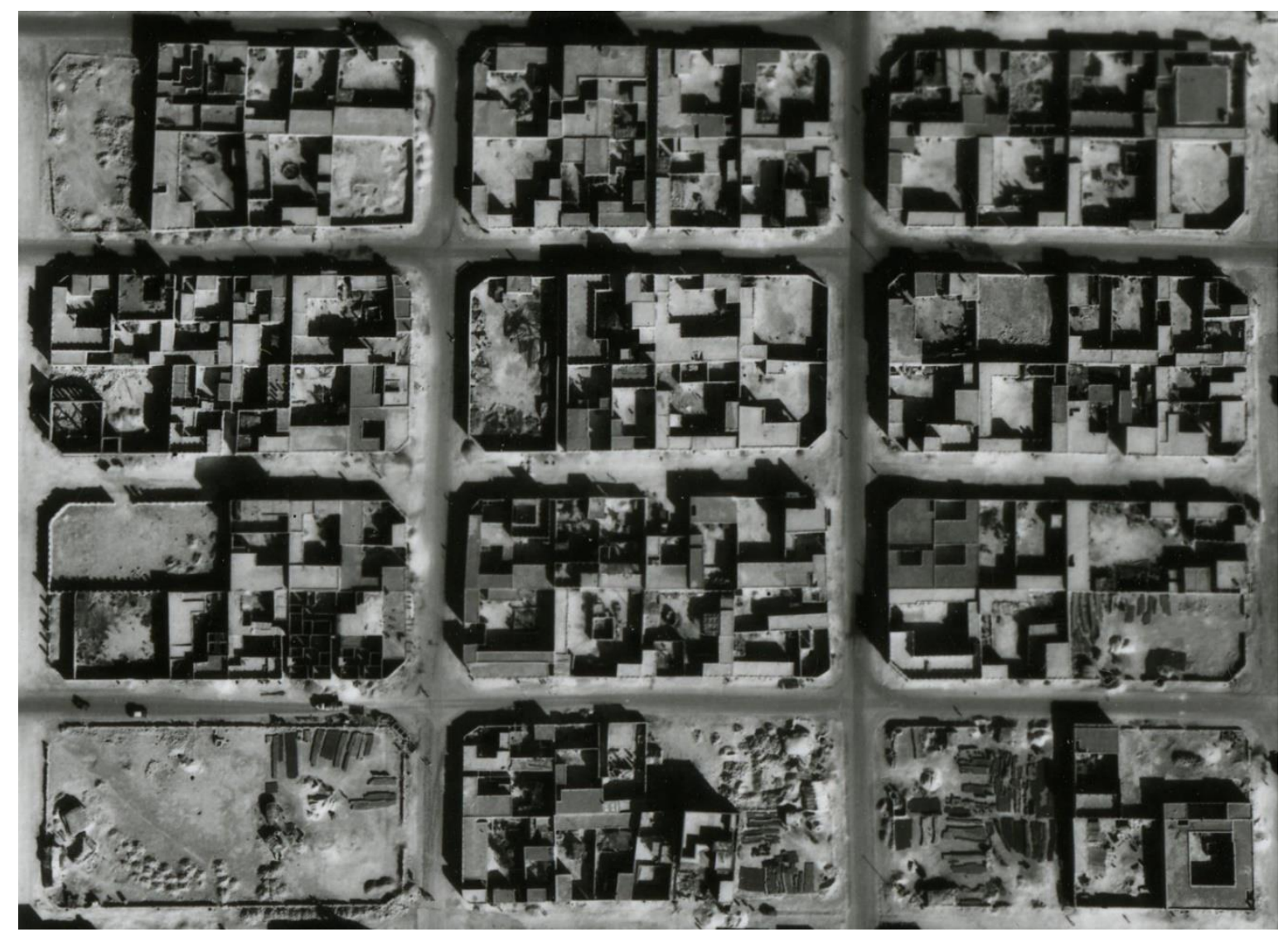

Figure 20: Part of Doha Al-Jadeeda in 1959, showing variation in construction within each family compound. Building had begun in 1953.

|Apart from the new housing districts, the 1950s saw a flurry of construction of metalled roads. We note that the ring-road system which is today attributed to the recommendations of town planning contractors, specifically Llewellyn-Davies in the 1970s and 1980s (Nagy, 1997: 121), certainly preexisted their arrival, going back at least to 1963 , by which time the roads that became known as the A Ring and the B Ring already existed; the outline of the C Ring was already in place by 1965 (fig. 21). Although the post-oil ring-growth expansion of the city clearly differed from the modular and coastal pre-oil growth pattern, whereby relatively-self-contained districts tended to appear along the sea-shore, this ring-growth was ultimately structured by the location and outline of the suq and the old town. 


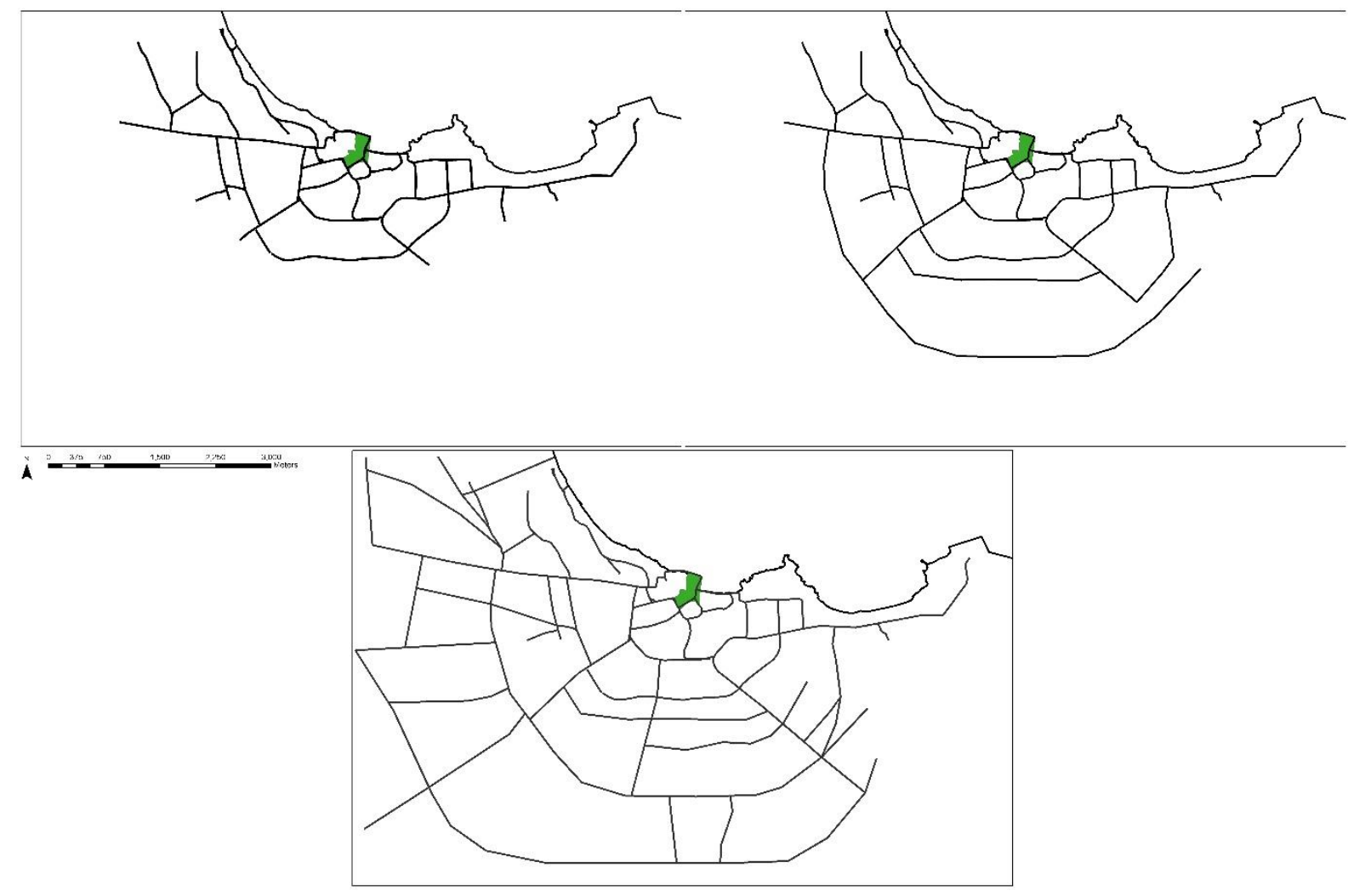

Figure 21: Road growth during the post-oil period.

The 1950s also saw extensive land reclamation (evident by 1956), an airstrip, the Law Courts, a massive expansion of the Amiri Diwan buildings to incorporate new government departments and administrative offices, police headquarters, a modern hospital, primary and secondary schools, a power plant, a separate large desalination plant and expanding distribution networks for water and electricity, all products of the developing central administration (Hay 1959: 110-111; Crystal 1990: 128-129).

\section{Patronage}

Compared to the rapid and state-managed development of new housing districts that followed the advent of oil revenues (see above, Section 5), direction from above appears to have been a relatively weak structuring principle in the pre-oil town. Patronage nonetheless determined some of the broad parameters that affected its development, particularly in the foundation and population of new districts before the coming of oil. Firstly, there was a need to obtain agreement with existing sheikhly authorities to settle new arrivals: land was not terra nullius but rather in the gift of the ruling family, and community leaders needed to engage with patronage networks to negotiate access to the land and resources required to build new districts; one might surmise that access to stretches of suitable coastline for the location of warehouses and boat facilities was also determined thus. 
Secondly, community leaders in all towns of the Gulf formed foci for economic and social activity: "life revolved around the houses of merchants, 'ulama' and tribal leaders who organised assemblies in their majlises" (Fuccaro, 2009: 38). These leaders directly influenced the physical constitution of the town: tribal and merchant patrons financed the development of residential areas and the provision of services, including the establishment of mosques. Most mosques in Doha were named after the individual who supported its building or rebuilding (Section 12). Community leaders could also patronise or become associated with open public gathering spaces, barahih, (sing. Barahah). In one case in Doha such a gathering space, named after an individual of family, gave its name to a whole district (Barahat AlJufairi).

Patronage also determined the movement of people more generally into the town: migration in the region was conducted through a web of patronage, often but not invariably kin-based. Newly arrived immigrants, at the most basic level, needed food and housing to start a new life; they also sought an environment which reproduced their ideals of community life and spiritual fulfilment. Therefore, in places like Manama there are documented examples of local tribal leaders and community chiefs providing houses, land, shelter (e.g. palm frond structures known as arish or barasti), and often work to immigrants, distributing or renting to family members, distant relatives, clients and workers, all of which developed, enlarged and continued patronage networks. The result was that civic identity coalesced around local leaders. Bonds of patronage therefore "represented the single most important chain of authority shaping settlement" (Fuccaro, 2009: 92-100). Studies by ethnographers and anthropologists in Qatar give consistent and repeated examples of Qatari departures, arrivals and returns in the 1950s all involving familial contacts and close tribal connections helping with resettlement (Graham, 1978; Nagy, 2006; Nagy, 1997). This kind of patronage could extend well beyond Qatar and ultimately lead to permanent relocation and nationalisation of relatives from far afield: "in Qatar...the tribe, clan and family (extended) represent the three levels of the kinship system. Kinship shapes almost all the individual and group patterns of behavior. The net of relationships within this system extends to many generations and connects each tribe with its branches in areas outside of Qatar...the maintenance of these connections has made it possible for many tribal members to acquire Qatari citizenship" (Melikian and Al-Easa, 1981: 79). 
Moreover, the household and employees of a wealthy merchant or sheikh could number in the $100 \mathrm{~s}$ (e.g. the household of Khalifa bin Hitmi, which numbered 200 according to Crystal 1990: 117), and a significant proportion of the population of a district might be made up of the retainers of the community's leading families. These could be drawn from bedouin allies as well as kin. The retainers of the Al Thani were described as follows: "living in tent and barasti settlements near the numerous shaykhly palaces are entire tribes subsidized by the ruling family and who could be called on to help defend the regime if the need arose" (Crystal 1990: 148, citing Anthony 1975). Networks of migration and patronage were mobilized during the rapid population expansion that occurred following the coming of oil.

Patronage likewise accounts for the tendency for settlement to cluster around the seat of power, not only as a result of relatives, retainers and employees living in the vicinity of their patrons, but also because of convenience (proximity to the majlis and mosque of one's patron or potential patron) and, after the coming of oil, the provision of services, particularly water and electricity. One of the main reasons for the emergence of Msheireb as the most fashionable district of Doha during and after the 1950s was its very early acquisition of water and electricity, itself a direct result of the proximity of the district to the Amiri Diwan ${ }^{14}$. The impact of the development of Msheireb can even be seen in the Centre Point analysis shown in Section 1 (fig. 13), where its emergence dragged the centre of the town westwards from its previous position.

Patronage additionally accounted for the building of the most visible and essential institutions of urban life in the pre-oil town, the mosques. These not only included the district mosques (see below, Section 12), but also the sheikhs' mosques or Friday mosques of the town. The latter most notably include the Qubib mosque (Sheikh Jassim mosque) in Old Al-Ghanim, the Al Ahmed Mosque to its west, and the Sheikhs' Mosque next to the Amiri Diwan ${ }^{15}$. Some of these also provided the Quranic education and basic literacy that was available to children in the town prior to the 1950 s.

From the early 1950 s onwards a more direct kind of patronage structured the town: urban growth around the outskirts of old Doha was planned under the direction of the ruling family. This has been discussed above, under Central Administration (Section 1). Within the old town, however we see an additional

\footnotetext{
${ }^{14}$ According to Ibrahim Jaidah the section of Jasra directly opposite the Amiri Diwan also obtained electricity and piped water very early on, because of its proximity to the Diwan (interview with Tammi Moe, March 28 2013).

${ }_{15}$ The latter appears to have been known as the Saleh Suleiman mosque in the 1950s.
} 
manifestation of patronage, in the form of clear concentrations of barasti (palm frond) housing. We initially considered that this might be indicative of segregation by wealth, with poorer inhabitants inhabiting the cheaper barasti buildings. We now see it is a correlate of patronage: barasti was concentrated in those parts of town which had retained their population during the slump of the 1930s and 1940s, and such structures were built not in ruined or new areas of town but in the yards of houses which were already occupied (fig. 22) We therefore interpret the concentrations of barasti architecture as being indicative of population growth managed within existing social networks, as described above, i.e. the provision of shelter for returning family and newly hired staff at a time of economic improvement, prior to the construction of more permanent housing elsewhere.

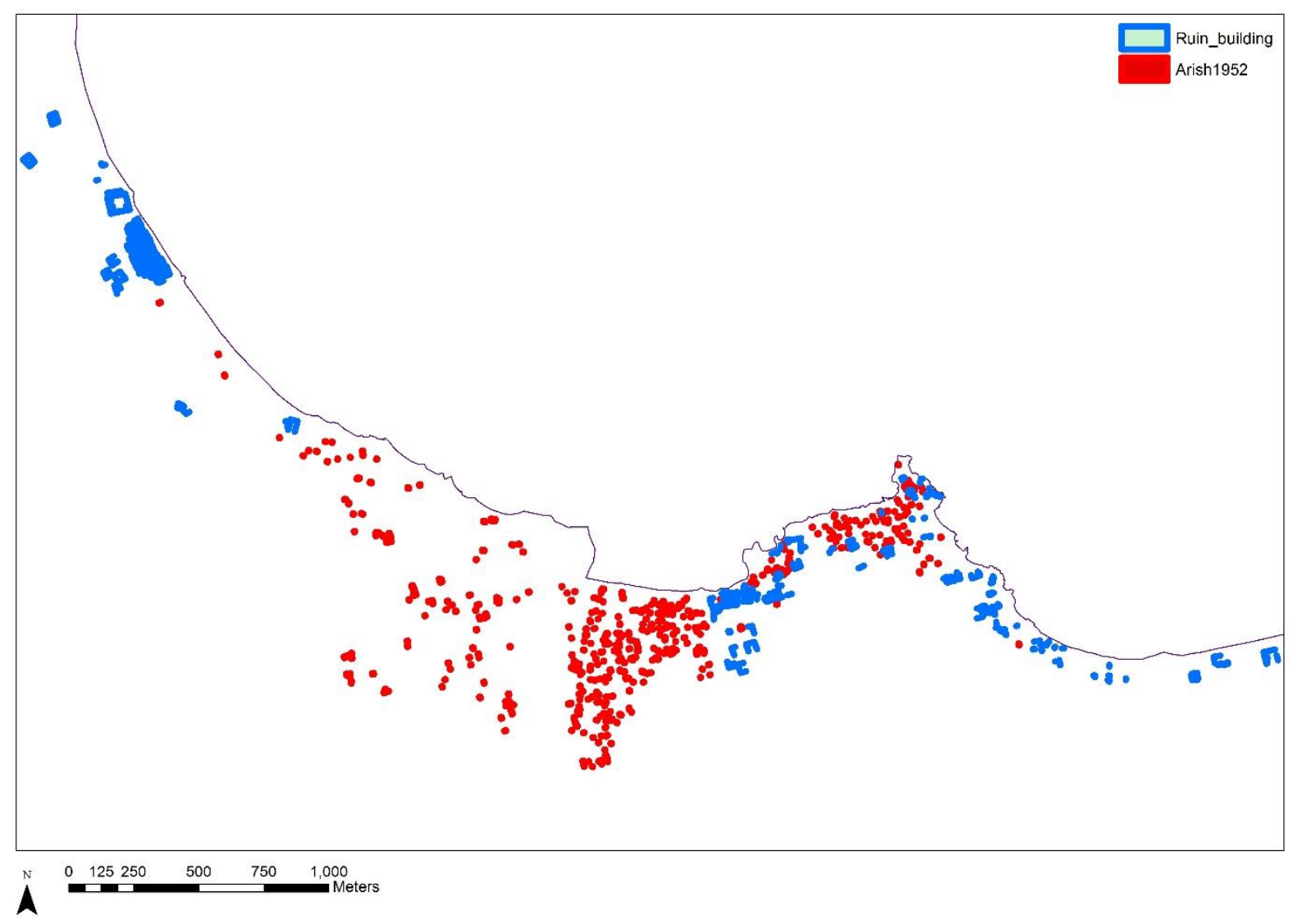

Figure 22: Distribution of barasti housing and ruined areas in 1952

\section{Historical role of defence}

The violence of life along the coast of Qatar and eastern Arabia is abundantly attested in the historical sources, and it was normal for the towns and villages of Qatar to have a central fort which doubled as the sheikh's residence. In the $19^{\text {th }}$ century it was also normal for Qatari towns, both large and small, to be entirely walled. The number of attacks and destructions suffered is hard to know exactly, but the British shelled Bida' and/or Doha in 1821, 1828 and 1841, and a combined attack by Abu Dhabi and 
Bahrain in 1867 caused the town to be "blotted from existence" and its inhabitants temporarily scattered (Lorimer, 1915: vol IB 892-894; Rahman, 2005: 76, 238). Thenceforth there were no further major attacks, and the role of Jassim bin Mohammed AI Thani and his successors in maintaining peace in Qatar is widely acknowledged. One of the most important roles of the traditional Arab ruler is to provide protection to his followers.

A major reason for the provision of town walls was for protection against bedouin raiders, who would carry off both livestock and people ${ }^{16}$. During the $19^{\text {th }}$ century, it was important to bring one's people and herds back within the wall before nightfall. The first map of Bida' and Doha, by Guy and Brucks in 1823, shows concentrations of buildings around two forts, presumably the fort of the Sudan tribe in Bida', and the original fort of the Al Bu 'Ainain in Doha (fig. 2). The latter was said to have been destroyed by the Al Khalifa soon afterwards, in 1828. Constable and Stiffe's description and map of 1860 (fig. 3) clearly shows separate town walls around both Bida' and Doha (they had not yet quite grown together), the one around Doha having at least five towers along it. In the western part of Doha was a further large tower, perhaps a surviving corner tower of Doha's first fort (visible in the 1823 map of Guy and Brucks), or a rebuild on the same spot. The building of the wall visible in 1860 may have been overseen by the Al Bin Ali under their powerful leader 'Isa bin Tarif, who had moved to Doha in 1843, or by the Al Thani when they moved from Fuwairit in around 1850. ${ }^{17}$

Constable and Stiffe's map additionally shows that by 1860 a new fort had appeared in between Doha' and Bida'. This was built by the Al Musallam around 1850, with the support of the Al Khalifa of Bahrain (Lorimer 1908: 488), who presumably hoped to control both Doha and Bida' from that stronghold ${ }^{18}$. During the 1870 s it became the base of the Turkish garrison and the inhabitants of Doha referred to it as the Qal'at Al-Askar ("Soldiers' Fort"), around which a small farī grew (also Qal'at Al-Askar). Confusingly, it was sometimes known to outsiders as both Bida' fort and the fort of Doha, though originally it stood in neither town. Soon after the Turkish withdrawal (in 1915) the Al Thani ruler, Sheikh Abdullah bin Jassim, moved his base from the Old Palace in Hitmi to the Turkish fort, and rebuilt it as

\footnotetext{
16 Palgrave notes that Manasir raiders were particularly problematic in this respect in the 1860s (Palgrave 1866: 233-4). The Manasir owed allegiance to Abu Dhabi, so a major reason for this might have been the long-standing conflict between the Al Thani and the Al-Nahyan in the 1860s-1880s.

${ }^{17}$ The Al Bin Ali moved to Doha in 1843 after around 8 years of wandering on both sides of the Gulf, following their expulsion from Huwailah by the Al Khalifa in 1835.

18 Lorimer says the Al Khalifa had it built to control the Sudan in Bida', but they were probably also intending to keep a close eye on the Al Thani and their followers, who had moved to Doha from Fuwairit in around 1850, and who were soon to throw off Al Khalifa rule.
} 
the Amiri Diwan. This was said to have deteriorated into a "decrepit and rambling old fort" by 1949 (Hay 1959: 110), and renovations and major additions had begun by 1952, the building being almost entirely remodelled in 1959. The Diwan still stands on the same spot, again since completely rebuilt and expanded.

In addition to the Qal'at Al-Askari/Amiri Diwan, and the now-vanished original forts of Bida' and Doha, square fortifications with corner towers are also known at two other localities: next to Suq Waqif (the Kut, possibly built in 1925 [Kholaifi 2006: 95], and still standing); and in Rumeilah, ca. 1.7km northwest of the Amiri Diwan, where the outline of a ruined fort can be seen in the 1950s aerials. The latter is probably the so-called White Fort first attested to in the 1915 Persian Gulf Pilot, which must equate to a "W. Kastel" shown on a German map of $1922,{ }^{19}$ located on same part of the coastline as the ruin visible in the aerial. Defensive architecture is also present in the form of small round look-out towers (a rebuilt example still stands overlooking Bida' park), and defensive breastwork shown on Constable and Stiffe's map, and on a 1915 sketch of the Ottoman fort (Qal'at Al-Askar) (Rahman 2005: 201).

Despite the relative security after the 1867 destruction, conflict continued (mainly with the Sheikh of Abu Dhabi and his bedouin auxiliaries) and Doha's wall appears to have been rebuilt in the $1880 \mathrm{~s}$. A document found by Mr Mohammed Ali Abdullah during the rebuilding of Suq Waqif is said to refer to the building of the city wall in 1888 (Cooke 2014: 92). This was said to have been completed by Sheikh Jassim before he set out for a retaliatory raid against Abu Dhabi following the death of Jassim's son during a raid on Doha. Jassim's wall may have been a rebuild of the 1860 wall, or possibly an entirely new one around a larger area to accommodate a newly expanded town. As far as we know this was Doha's final city wall.

Neither Burchardt (1904) nor Lorimer (ca. 1907) mention a city wall20. We surmise that the town had outgrown its walls in places by this time (for example in the new suburbs of Nejd and Jasra), and the improved security situation and good relations between the Al Thani and the bedouin under the later rule of Sheikh Jassim no longer rendered a city wall necessary. Finally, we note that the footprint of

\footnotetext{
${ }^{19}$ Indischer ozean Arabische et Persische Küste Persische golf Herausgeben vom REICHS-MARINE-AMT http://www.oldmapsonline.org/map/muni/3145900284.

${ }^{20}$ At first glance a 1904 photograph taken by Burchardt from the Turkish fort appears to show walling along the western side of Doha. Closer examination, however, shows that it is no more than a sequence of house and compound walls, broken in places by entries to the town
} 
Doha's 1860 wall, around the original core of Doha proper, remains encoded in the structure of the city today.

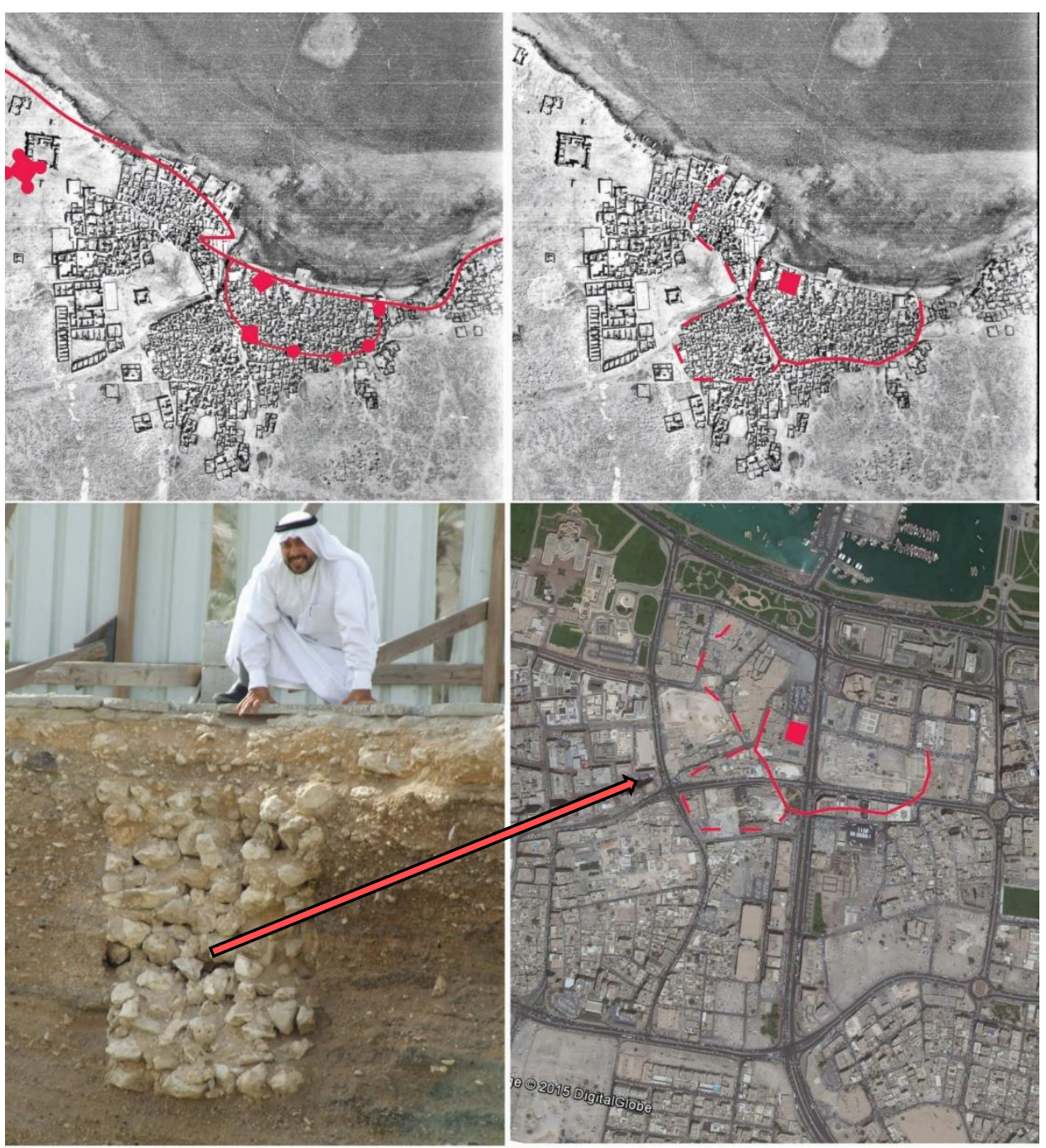

Figure 23: City Walls of Doha: overlay of walls of 1860 map in 1947 aerial (top left), with hypothetical precise location of walls and Doha fort using 1947 street plan (top right) and 2015 street plan (top left), also showing outline of town in 1904 (dotted). Mohammed Ali Abdullah is seen with a cross section of city wall found during the reconstruction of Suq Waqif (bottom left).

\section{The importance of the sea.}

All of the Gulf towns "looked to the sea as their main source of income, social prestige and political legitimacy" (Fuccaro, 2009: 28). Until the discovery of oil, Doha was almost wholly dependent upon the trades practised upon the sea: local commerce, fishing and particularly pearling (Carter 2012: 164). Mohammed bin Thani famously stated to Palgrave around 1865 that "We are all slaves to one master, Pearl", while according to Lorimer "the principal and almost the exclusive source of livelihood in Qatar is pearl-fishing" (Lorimer 1908: 1532). This relationship with the sea is most clearly manifested by the expansion of the town along the shore in the $20^{\text {th }}$ century before the discovery of oil, illustrated below 
(fig. 24, fig. 25). That this is related to the dependence of Doha on the sea is demonstrated by the way in which expansion changes to inland growth as soon as oil is discovered.
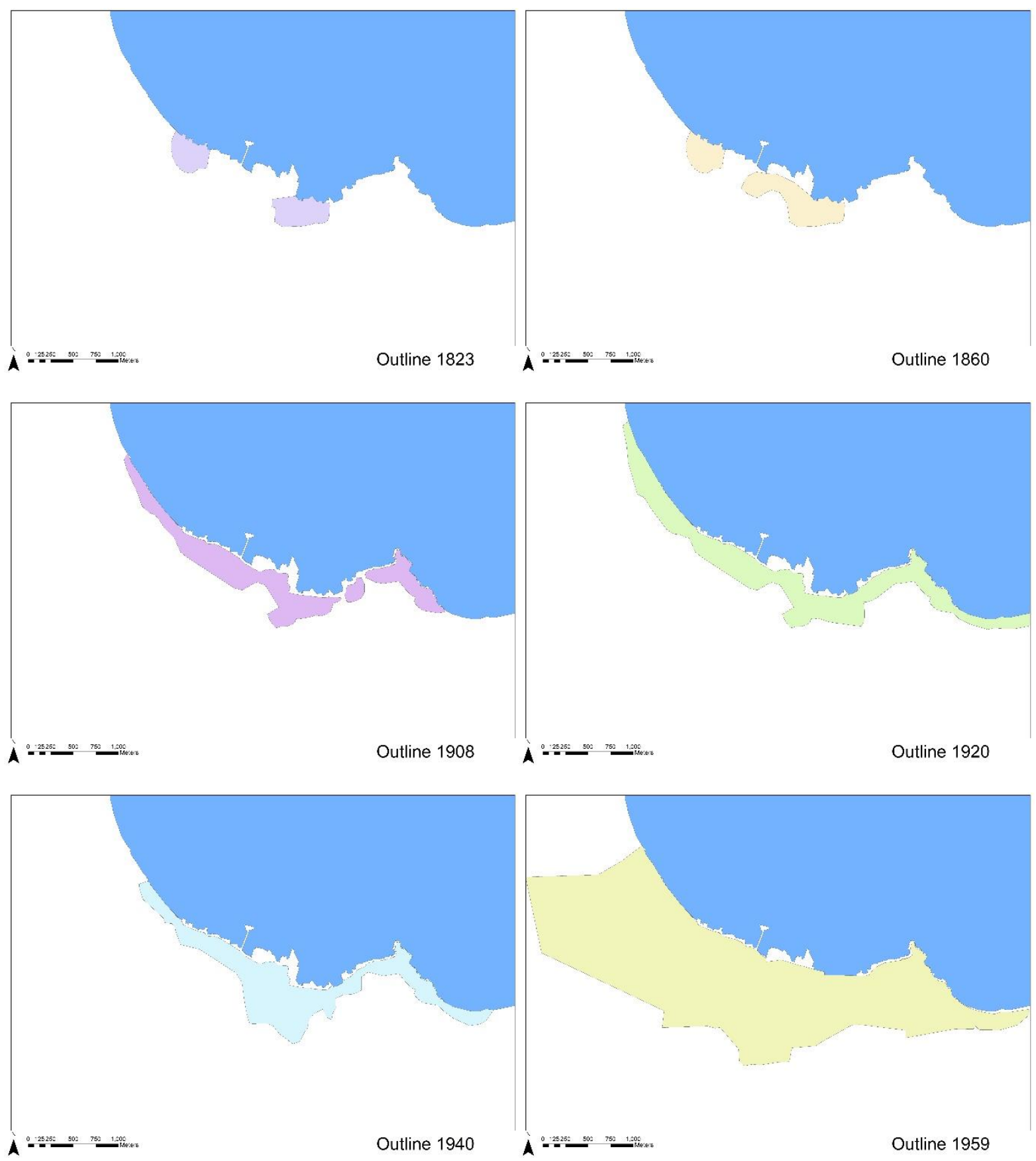

Figure 24: Expansion of Doha, 1823-1959, showing initial extension along coastline followed by inland expansion after the coming of oil.

It is also apparent that during the years of decline between the 1920s and 1940s the contraction that occurs is again along the shoreline, with dwellings at the extremities to the east in Farij Al Khileifat and to the west in Rumeillah being abandoned. 


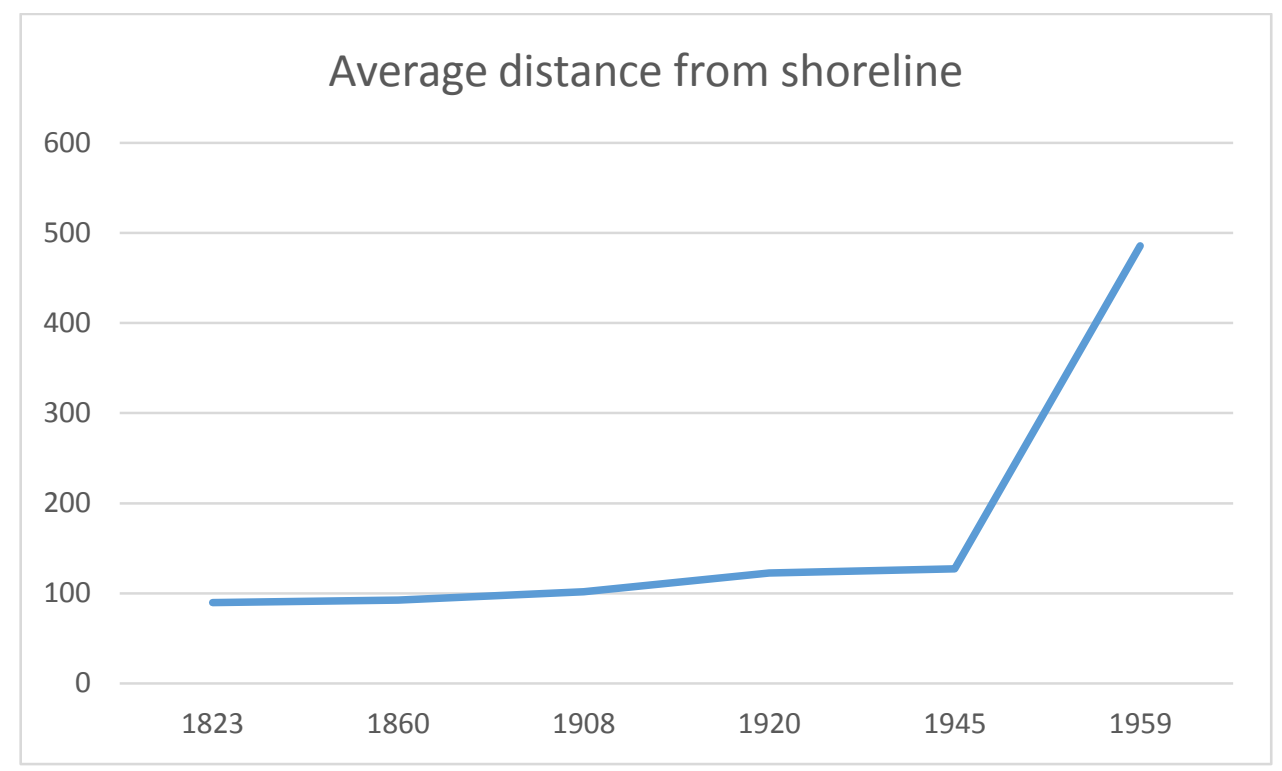

Figure 25: Average distance of building from the shoreline, 1923-1959.

Regarding commerce and cosmopolitanism, the Gulf towns all to some extent developed as part of a network connected "to the world of trade, merchants and trans-continental routes extending from the Mediterranean and the Red Sea to South East Asia" (Fuccaro, 2009: 43). As such they manifested influences in architecture, language, and urban organization from many parts of the region, particularly Arabia, 'Iraq, Persia, India and East Africa. However, Doha was in many respects considerably less cosmopolitan than most of the other Gulf and Omani towns, partly owing to the success of Sheikh Jassim in keeping British interests at bay during the last quarter of the $19^{\text {th }}$ century, which resulted in the effective exclusion of Indians and British subjects from Doha until the late $1940 \mathrm{~s}^{21}$. Unlike some other Gulf towns (particularly Manama, Dubai, Kuwait) Doha was never a trading entrepot other than to the people of Qatar and the local bedouin tribes.

\section{Access to Drinking Water}

There are two aspects to the analysis of water in Doha. The first is access to fresh drinking water, the second is the disposal of waste water. Besides numerous brackish wells within the town's private house compounds, used for washing, drinking water was accessible in the early $20^{\text {th }}$ century at Msheireb (monopolized by the Turkish garrison until their departure), at Bir al-Jadida (said to be of "indifferent" quality and possibly visible in the 1947 aerials as a cluster in what is now Muntazah Park) and at Nu'aija

21 Lorimer states that there were no British subjects (Indians) in Qatar in 1908. British records give the number of Indians (including Pakistanis) in 1937 as precisely one, but by 1948 the total had become 4,000 though most of these were employed in the oil fields outside Doha Tuson P. 1991. Records of Qatar 18201960, London: Archive Editions Limited. 
(which provided the best quality water, used by the Turkish officers and the notables of the town) ${ }^{22}$. There was also a public well, 'Ain Walad Said, half a mile south of Doha (probably close to todays' junction between the B Ring and Rawdat Al-Khail) but it was said to be "brackish" (Lorimer 1908: 491), and a public well was also found in Jasra next to the Eid prayer ground, named as the Youssuf Ahmad well by Othman (1984: 8), which is visible in the 1950 s aerials lying $120 \mathrm{~m}$ to the northwest of the corner of the Kut fortress. Another named well, the Qu'oud well, was said by Othman to have been covered by the Qatar International Hotel, itself now demolished. This was located at the eastern edge of the Msheireb well cluster. There were numerous other wells within $10 \mathrm{~km}$, but the wells most often used, including all those listed above, were within $4 \mathrm{~km}$ of the edge of town. Drinking water was bought by the townspeople from water-carriers, kandari, who brought it by foot or with donkeys from the well fields.

The advent of diesel pumping in the 1950s had an immediate effect: water was being piped into town from unnamed wells "at some distance from town" by 1955 (Hay 1955: 369). The source may have been Muraikh, named by Othman as a source of good water in the 1950s. At the same time the first desalination plant was coming into use, according to Hay.

22 The well field and an agricultural area in Nuaija has been archaeologically investigated by the Origins of Doha and Qatar team (Eddisford \& Carter 2015) 


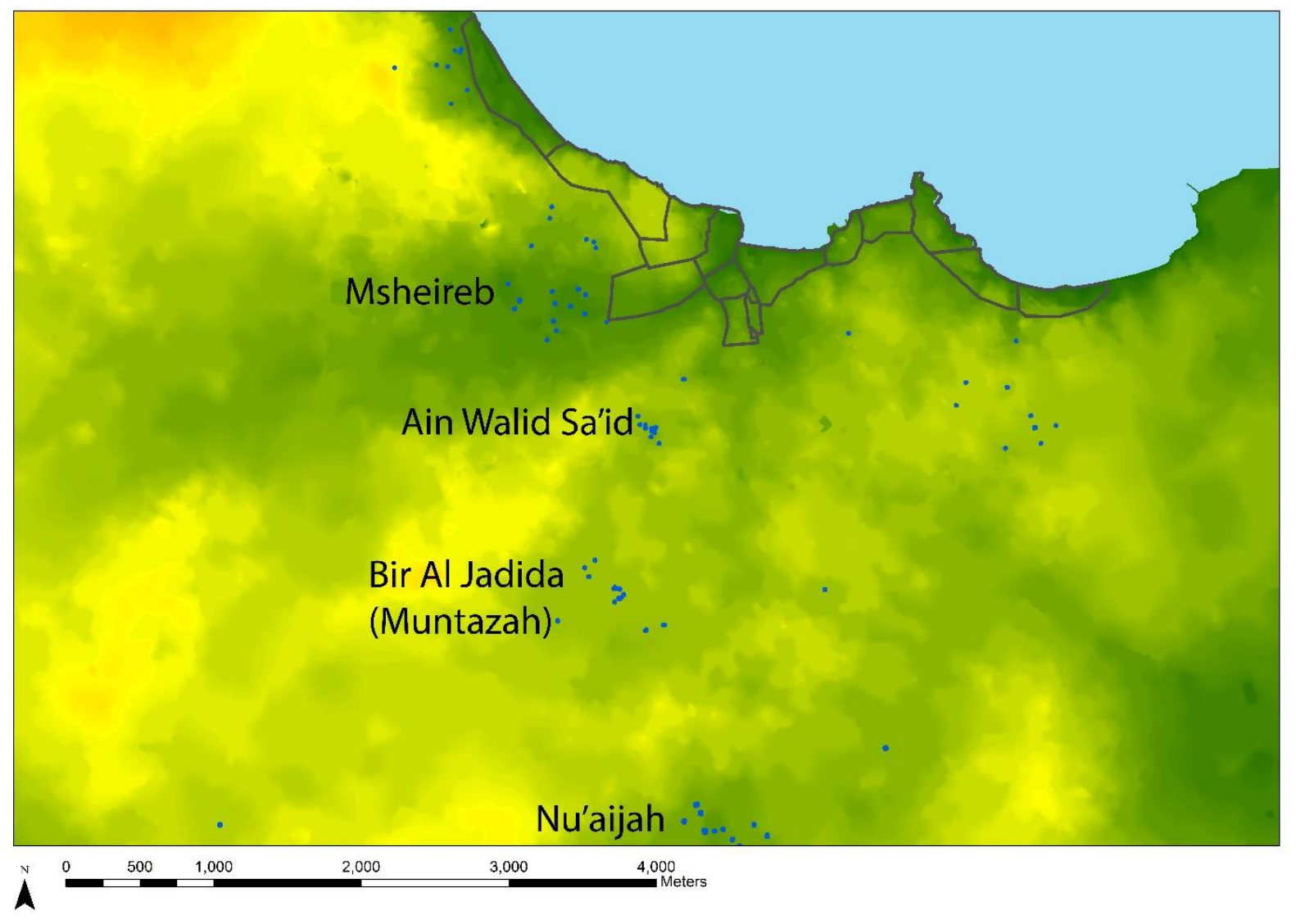

Figure 26: Fresh water wells within $4 \mathrm{~km}$ of Doha.

The lack of good fresh-water supplies inside the town was actually beneficial to health and sanitation. Reports on health in Bahrain in the $19^{\text {th }}$ and early $20^{\text {th }}$ centuries mention epidemics of plague and cholera, as well as various forms of conjunctivitis, tuberculosis, parasitic diseases and malaria (Yarwood, 1999: 73-4). In Doha the earliest reports date from the 1940s when Dr. Steele reported on the presence of smallpox, conjunctivitis, dysentry and typhoid fever, but was mainly concerned about malaria (Trench, 1994: 3, 42). The lack of concern about cholera and diseases other than malaria implies that general drainage and sanitation within the town were good. One of the main factors identified in Bahrain as contributing to outbreaks of cholera and typhoid fever was the infiltration of waste water into the water table from cesspits, septic tanks and other drainage (Yarwood, 1999: 73-4).

In Doha the arrangement of the town made this impossible. One can see from the DEMs and from watershed analysis that all waste water from the town naturally drained towards the sea and not into the watertables of the wells. The proximity of the town to the shore, the well-drained soil of Doha and drainage towards the sea and away from low lying land (and wells) means that there was never a serious problem with standing water. 


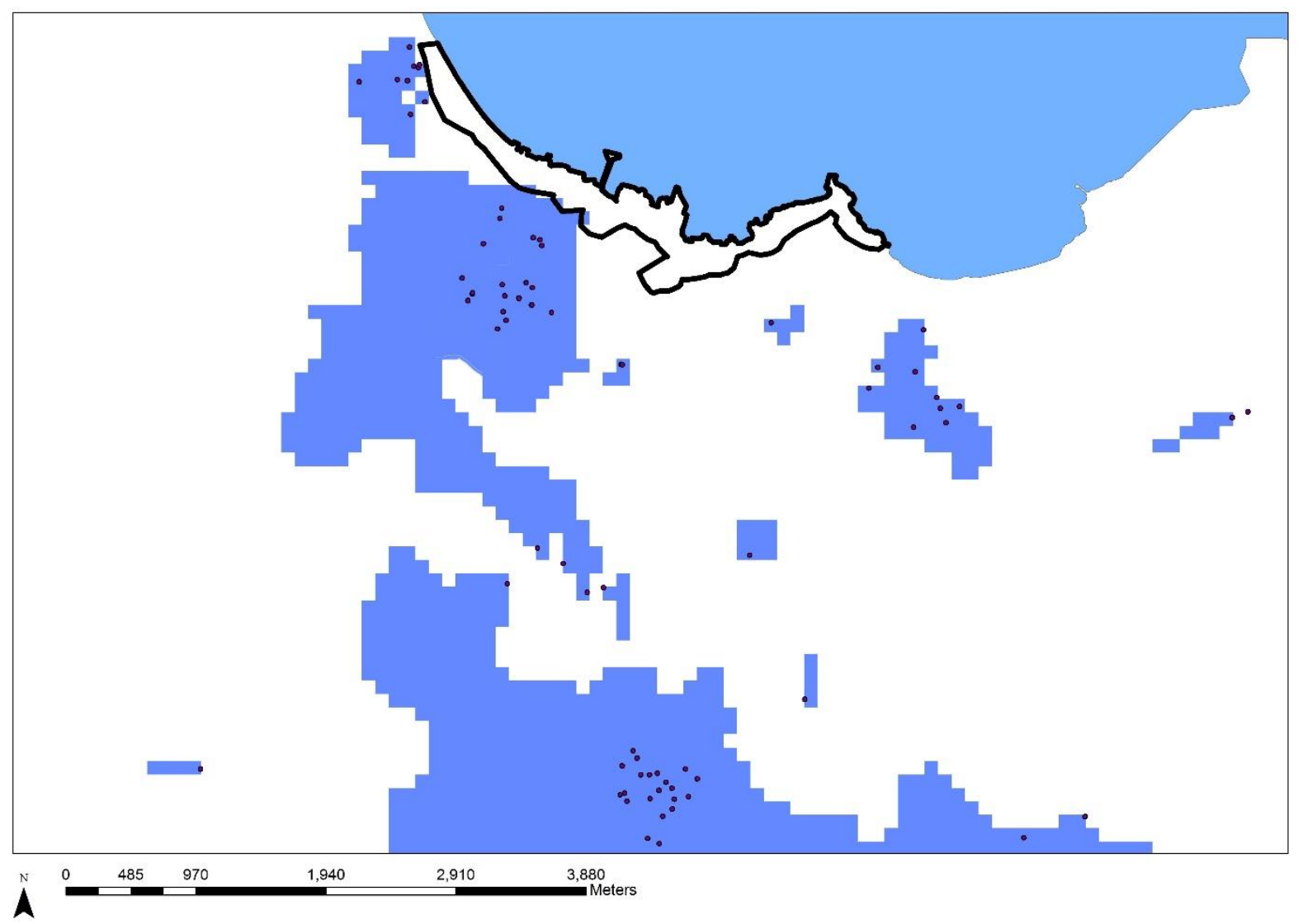

Figure 27: Watersheds for fresh water wells close to Doha, showing their exclusion from the footprint and drainage of the town.

\section{Access to Resources and Communication}

Factors concerned with day-to-day existence allow us to understand not only the built anatomy of the town, but also the lived experiences of its inhabitants. We have therefore examined access to essential resources, framed here as access to the market area (thus staple food and other supplies), access to water, access to the sea and access to mosques. We have used cost surface analysis, which calculates "cost-weighted distance" maps ${ }^{23}$. In the maps shown below, yellow signifies highest access through to blue indicating lack of access.

${ }^{23}$ The ArcGIS Spatial Analyst tools for the analysis of movement consist of the "Distance Toolset" which allows for the analysis of movement as Euclidean (straight-line) distance, cost-weighted distance, costweighted distance allowing for vertical and horizontal restrictions, and paths and corridors between sources with the least cost of travel. Naturally, the third and fourth of these are most useful for understanding the movement of people on a landscape since one can produce maps of the ease of movement and the easiest (or least-cost) paths from one point to another. Such maps of the ease of movement are based upon a landscape map: a digital elevation map (DEM) of the terrain, on which buildings are added. This landscape map is made up of $30 \mathrm{~cm}$ pixels, each of which has a height. This enables the urban landscape to be transformed into a so-called "cost-surface" whereby each $30 \mathrm{~cm}$ pixel is given a value which can be used to analyse the "cost" or ease of moving through that pixel. Thus a relatively flat $30 \mathrm{~cm}$ square of land will have a low "cost" value, while a wall will have the very highest "cost" value ESRI. 2014. How cost distance tools work. 
Turning first to supplies we note that, like most Gulf towns, Doha and its environs was not self-sufficient in staple foods. The largest category of imports was, until recently, always foodstuffs, particularly barley, rice and dates, mainly from India and Basra (Anon, 1987; Fuccaro, 2009: 82). Fishing for food and for pearls were therefore crucial to the survival of the people of Doha, the former for providing the townspeople's chief source of protein and the latter for providing the cash required for purchasing the staples mentioned above. Although the short distances involved means that ease of access to the sea and the suq did not equate to a life-or-death situation, it can certainly be taken as an indicator of convenience and favourable location for habitation.

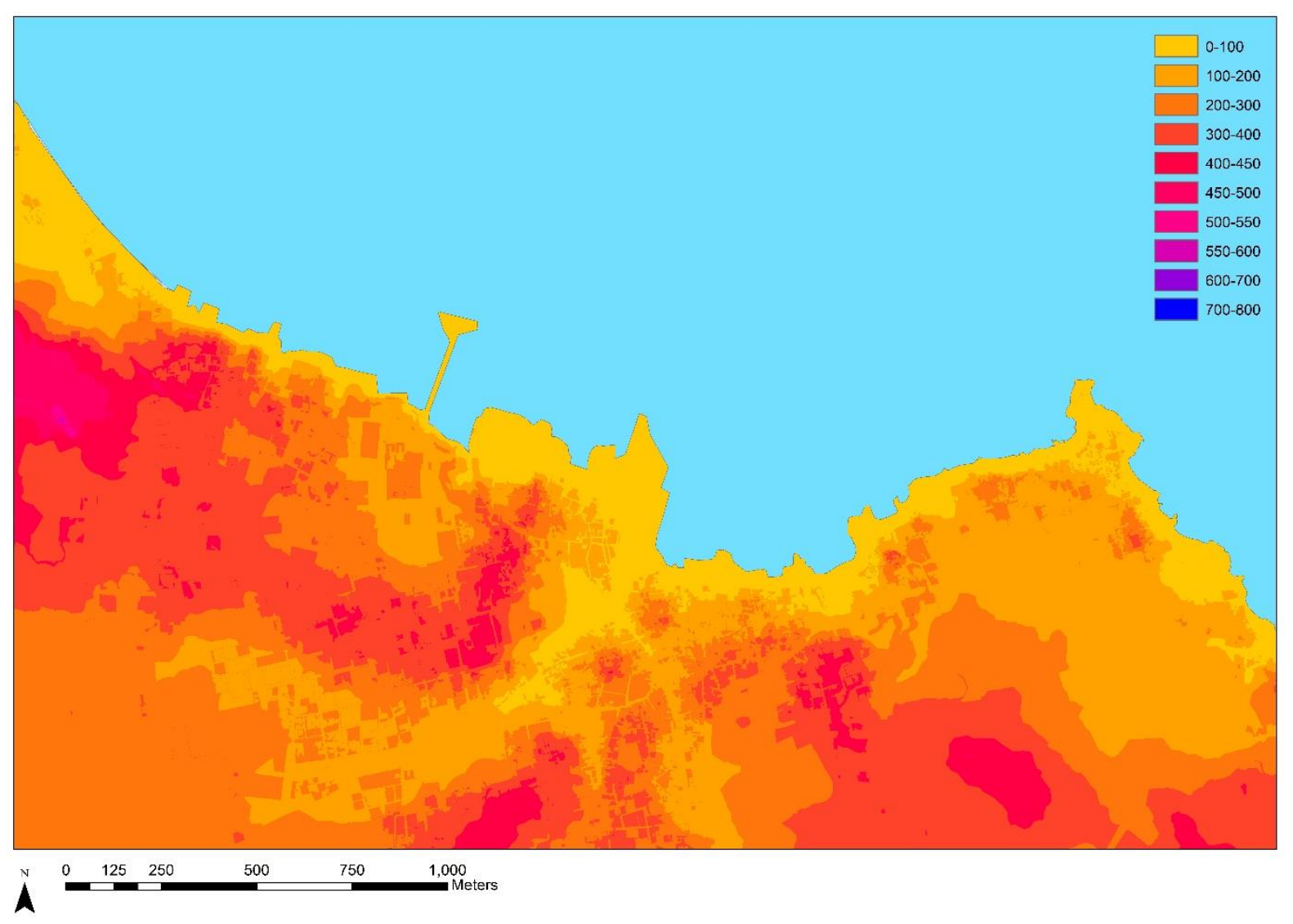

Figure 28: Cost-distance to the sea in 1952. 

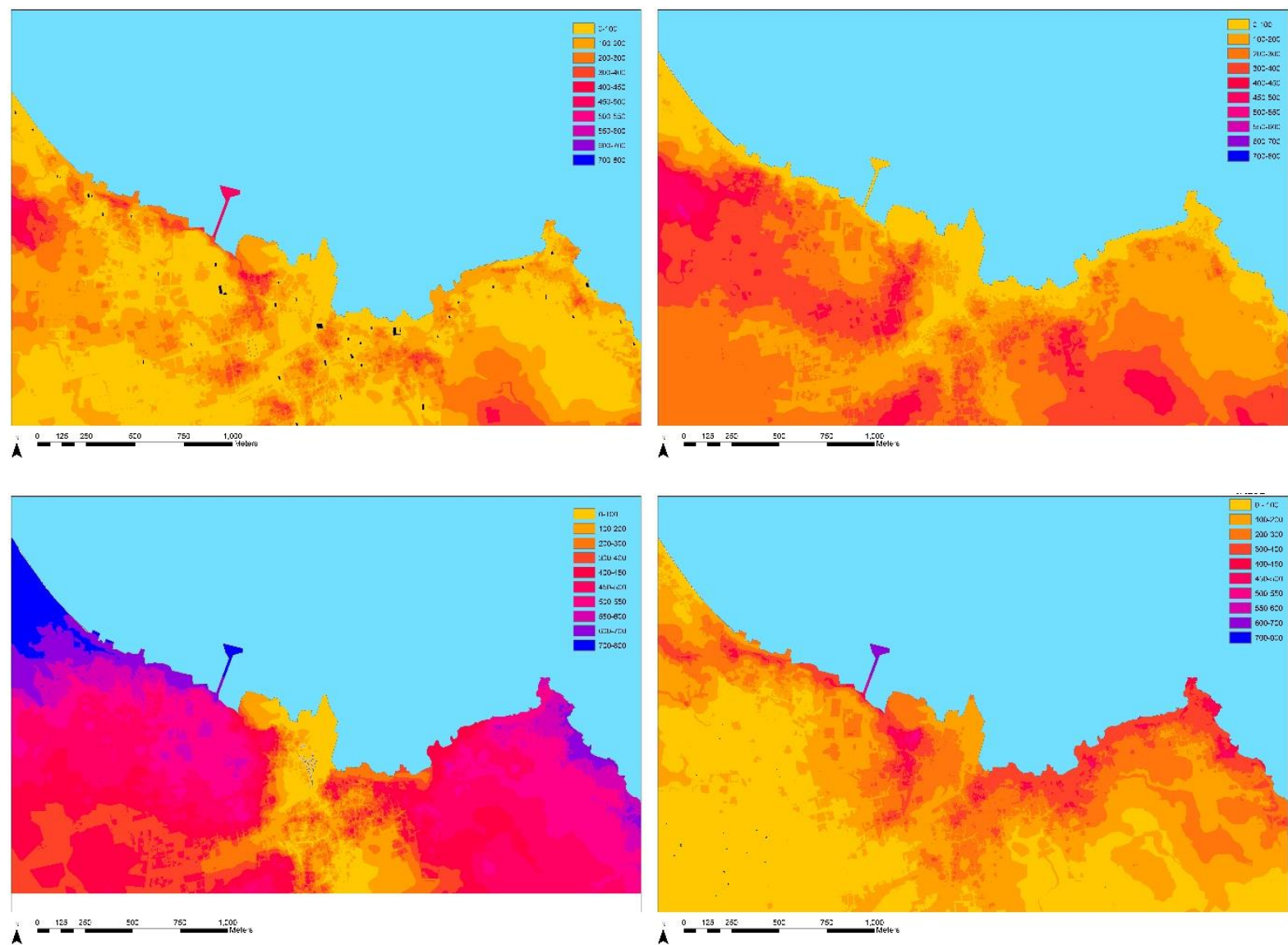

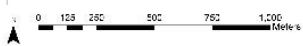

Figure 29: Cost-distance to the mosques, the sea, the suq and wells in 1952.

Superficially these maps indicate only the obvious: that proximity to the sea was along the coast, and that the central suq was usually best accessed by proximity. However, a closer inspection of the results shows how the compartmentalisation districts of the town showed a degree of variation. Shown below are comparisons between the neighbouring districts of Najada and Al Ghanim in terms of access to the sea. It shows that the heart of Najada district had an inner core of inaccessibility, and likewise the southwestern side of Al-Ghanim; these areas would have been mildly inconvenient locations to live in terms of easy access to the normal zones of commerce and professional activity. 

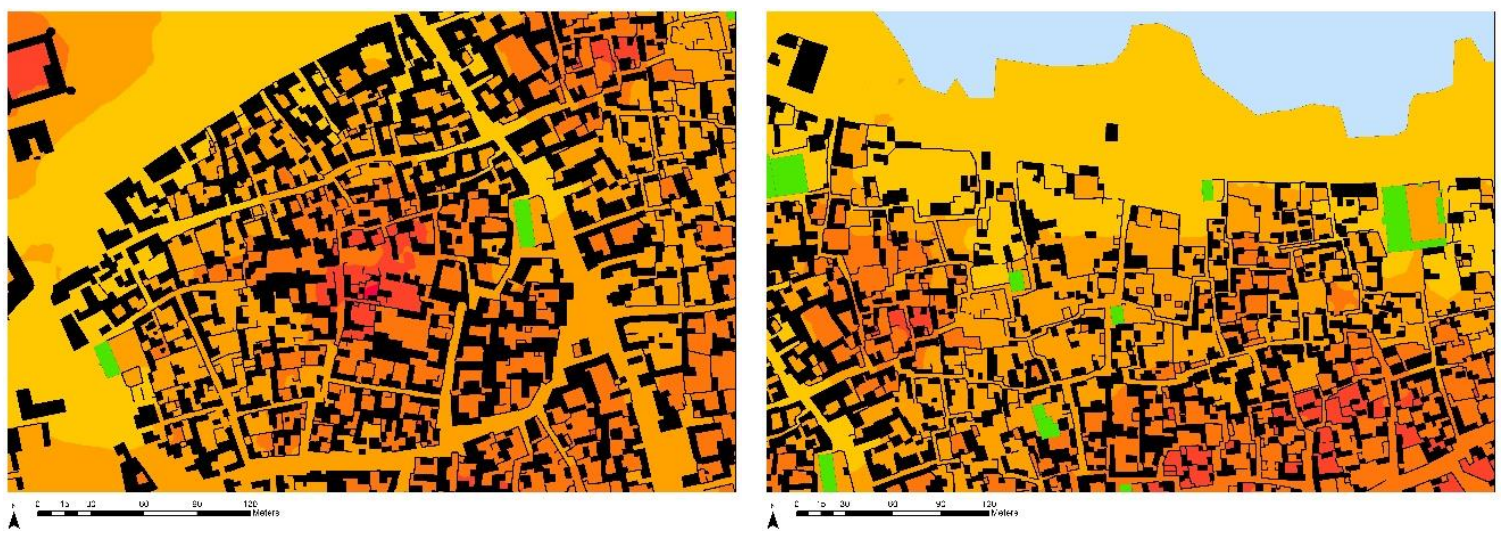

Figure 30: Access to the sea from Najada and Al-Ghanim, 1952.

Access to mosques can demonstrate the structure of the religious life of the town (Guindi, 2008). This is discussed in more detail below (Section 12), but here we present cost-distance map of the mosques of Doha. This shows that the older districts (Al Ghanim and Al Ahmed, both comprising the oldest part of Doha proper) had relatively good access to mosques, while certain others of the late $19^{\text {th }} /$ early $20^{\text {th }}$ century expansion did not, for example Hitmi, Jasra and particularly the core of Ahl Al-Nejd. This partly reflects the length of habitation, insofar as the longer a district is inhabited the greater the number of new mosques founded through time, and also (in the case of Nejd) the relative inaccessibility of the interior of the district. 

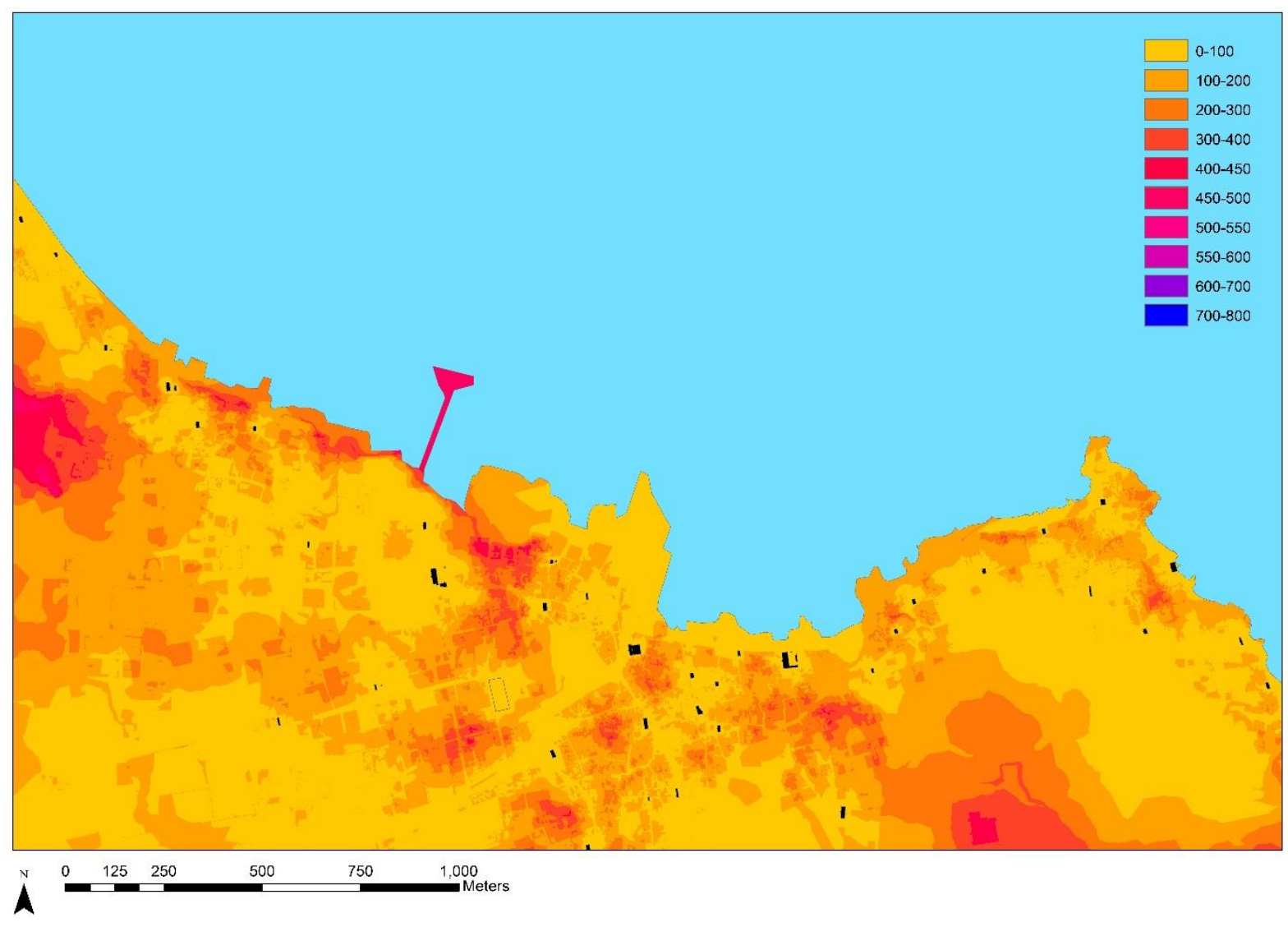

Figure 31: Access to mosques in 1952.

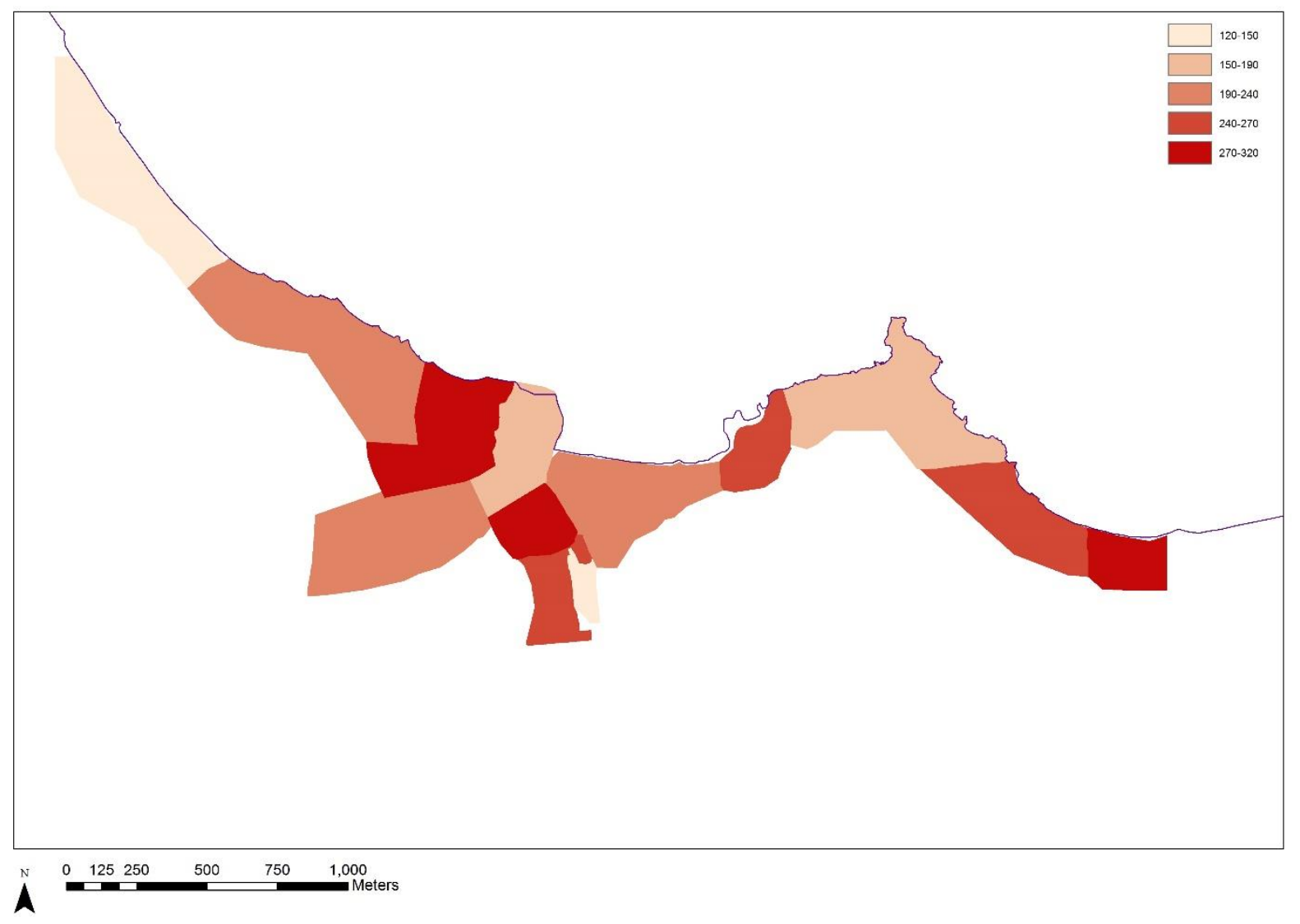

Figure 32: Access to Mosques, by district, in 1952. 

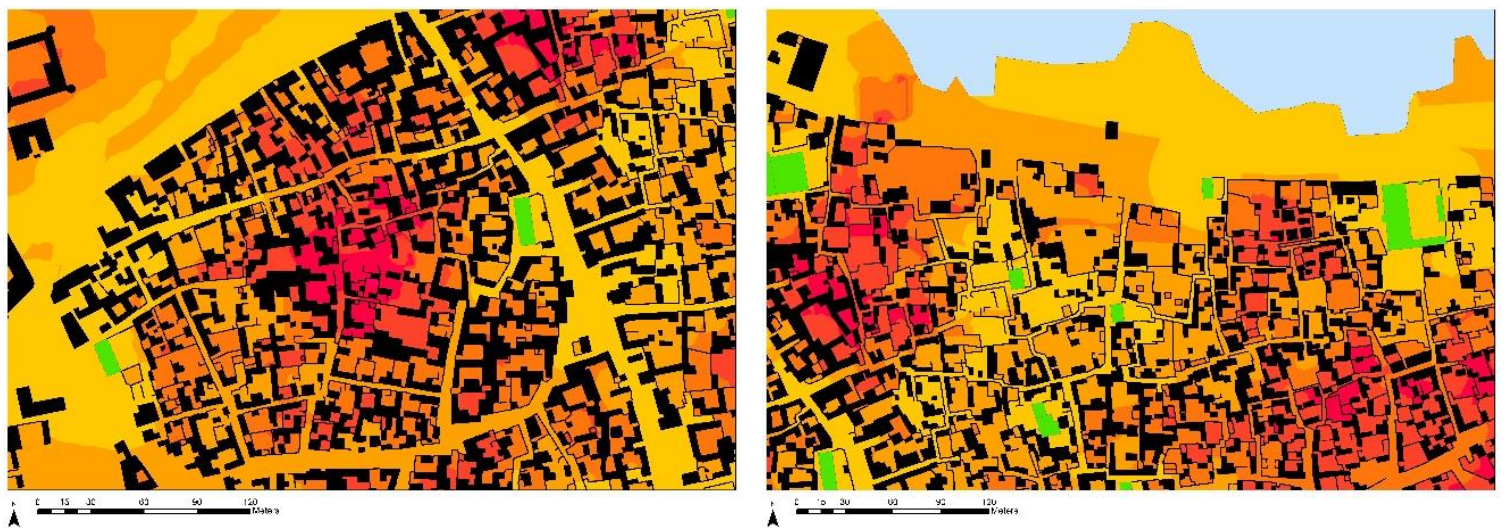

Figure 33 Access to mosques from Najada and Al-Ghanim, 1952.

Regarding access to drinking water, as noted above (Section 9) townspeople either travelled to collect the water themselves, or bought it from kandari who travelled between Doha and the well fields (Othman 1986: 8; Lorimer 1915: 491). Moreover, access to the best water appears to have been restricted to colonial or ruling elites .Because of the use of wells outside town, the ability to buy it from water-carriers, the lack of data on the productivity of the various wells, and uncertainty as to who was allowed to use which well fields, the cost-distance to wells map given below is of uncertain significance.



Figure 34: Cost distance to wells in 1952. 
These analyses demonstrate that the oldest parts of Doha (Al Ghanim and Al Ahmad) had considerably better access to the sea, to mosques, to water and even to the suq than adjacent more recent districts. If we combine the various cost-distance maps (access to the sea, to the suq, to mosques and to wells) to produce a "Combined Access" map, the results confirm the centrality of the oldest parts of Doha proper, as well as the compartmentalisation of the town noted in Section 3. Bida' had by this time been marginalised, and the newer suburbs of the late $19^{\text {th }} /$ early $20^{\text {th }}$ century largely enjoyed a less privileged position. A patch of good access in Hitmi, on the eastern side of Ras Nessa, corresponds to the location of Sheikh Abdullah's palace; this may not be coindidental.

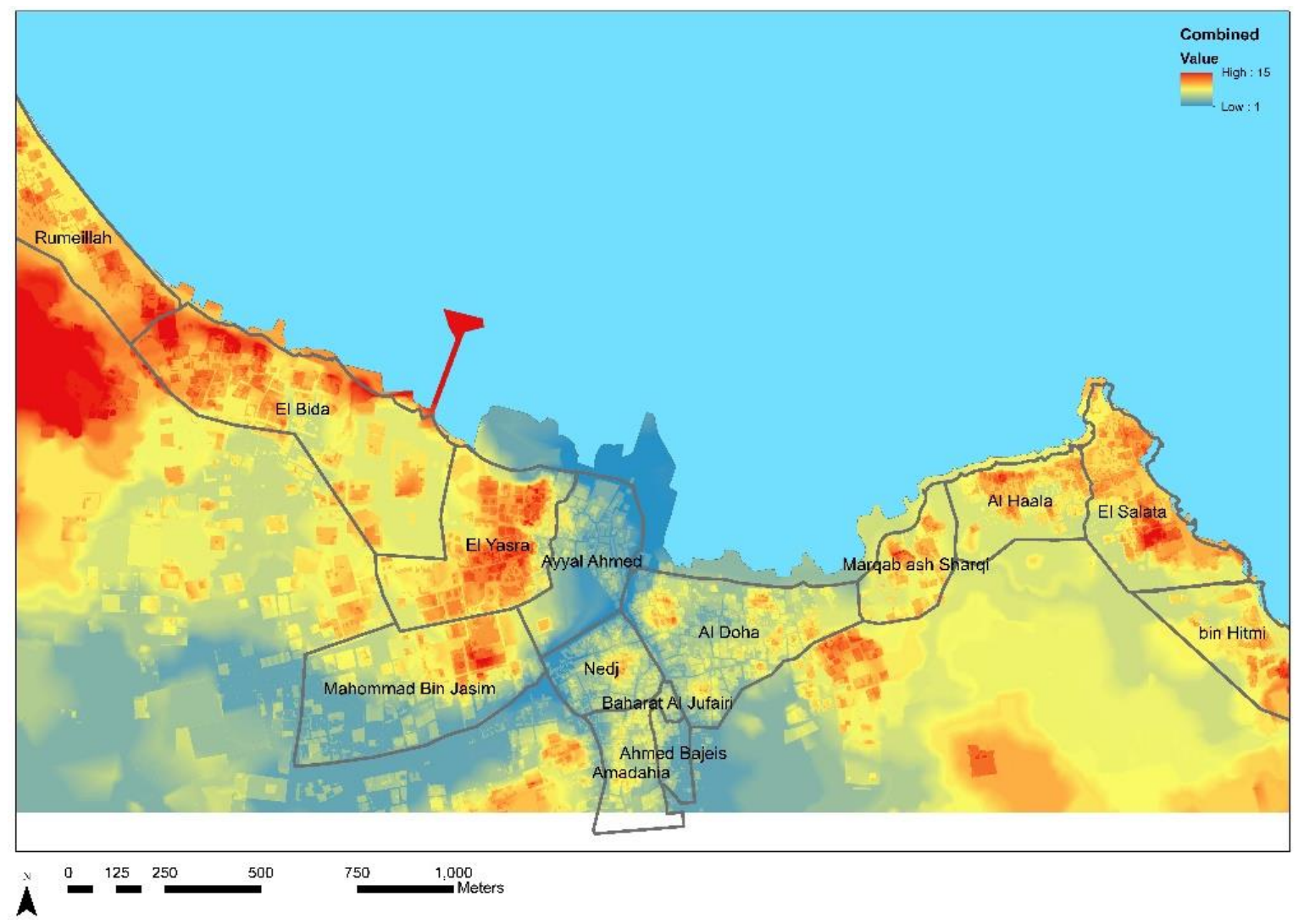

Figure 35: Combined Access map of Doha in 1952.

\section{Climate}

Protection from wind and sun is a critical architectural concern in the harsh climate of the region. The consistent orientation of the buildings of traditional Doha, calculated as the "Linear Directional Mean" of all the walls and buildings of Doha, appears to reflect the prevailing wind direction, and we suspect this is adaptive to local climatic conditions. ${ }^{24}$ Orientation is consistently between 247 and 252 degrees, which is roughly perpendicular to the prevailing north-westerly winds (fig. 36). While this may also reflect

${ }^{24}$ ArcGIS defines Linear Directional Mean as: "The trend for a set of line features is measured by calculating the average angle of the lines. The statistic used to calculate the trend is known as the directional mean. While the statistic itself is termed the directional mean, it is used to measure either direction or orientation." 
that buildings tended to follow the alignment of mosques (Mecca lies at ca. 252 degrees from Doha) ${ }^{25}$, the houses were nonetheless designed to use prevailing winds to cool the interior (Haider, 2008), particularly with the use of wind-catching devices set in walls and parapets (badgir), which require the walls to face the prevailing wind (Lewcock, 1978: 41; Nagy, 1997: 389-392). Historical imagery shows that Iranian-style wind-towers were very rare in Doha.

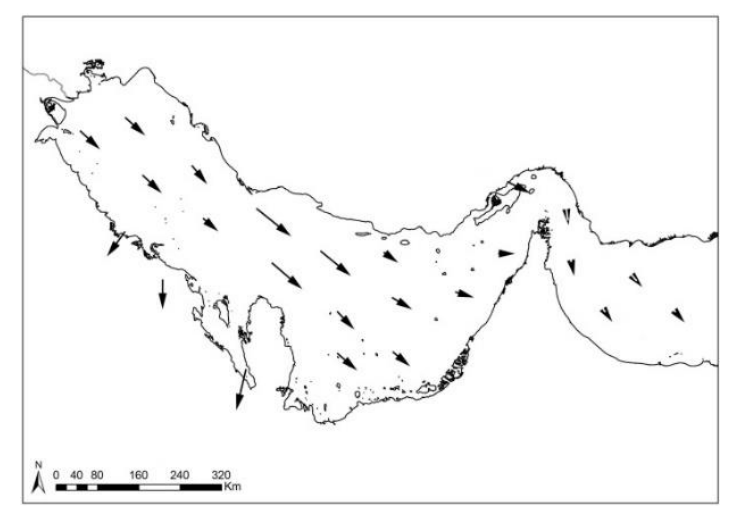

Winter

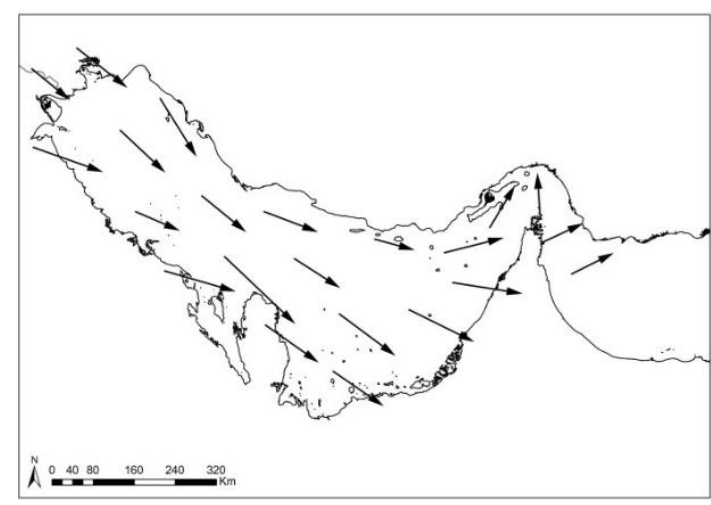

Summer

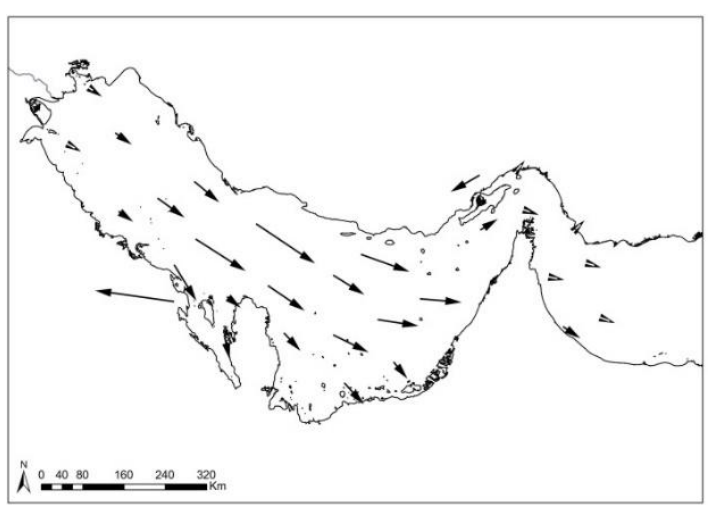

Spring



Autumn

Figure 36: prevailing winds.

${ }^{25}$ Preliminary examination of other traditional Gulf towns suggests that wind direction and alignment parallel to the shoreline are more powerful factors in determining building orientation than Qibla. 
Since the earliest times, the architecture of the Middle East has been developed to provide shelter from the searing heat of the sun (Shepperson 2009: 363-9). Shade is critical, given that summer temperatures peak at more than $50 \mathrm{C}$, consequently "there is a need for the built environment to help mitigate the hardships of this extreme climate by providing shade, ventilation and insulation" (Nagy, 1997: 32). The alignment of the housing may account for ventiltion, but the provision of shade can only be achieved by the use of awnings, canopies, loggias and by dense city plan. The well-known narrow streets and alleyways of the Arab world had this planned effect, in that they maximised shade. However, the disadvantage of this was to restrict airflow. This may provide a functional explanation for the density of housing in the Nejd district: being inland it was less exposed to the sea breezes, for which compensation was achieved by dense construction and hence extra shading. Its shaded character can be shown by contrasting share at 3pm in Nejd and in the shoreline district of AI Ghanim (fig. 37).

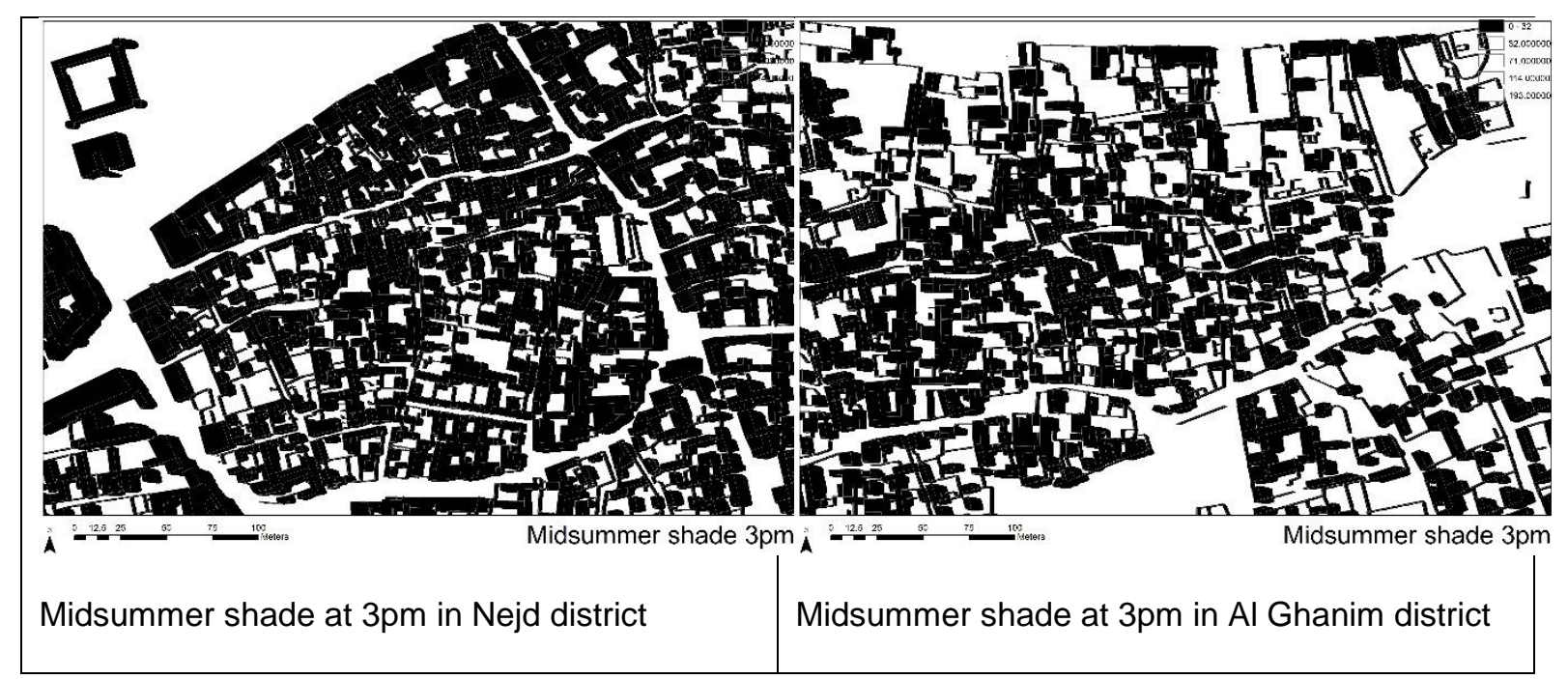

Figure 37: Shade at 3pm.

Finally we note that as well as the use of wind-catching devices and shade, the traditional architecture of Doha and its usage showed other adaptations to the local climate, including thick walls, a courtyard arrangement, a lack of windows, a focus of activities in collannades (liwan), courtyards and on the roof. These will be dealt with in detail in another publication.

\section{Religion and Mosques}

Doha was full of mosques. The most popular and important were the Sheikh's Mosque alongside the Fort, the al-Ahmad Mosque and the Jassem [al-Qubaib] Mosque .... which was unique in its architecture and quite the most beautiful mosque to be found anywhere in Qatar. The main open- 
air mosque used at major festivals such as the Eid al-Fitr, which follows the holy month of Ramadhan fast, was in al-Jassrah (Othman 1984)

The day-to-day and annual tempo of life in any Muslim town is dictated by the five-times daily call to prayer, and by the Muslim lunar calendar, with its rhythms of fasting and festivals (Guindi: 2008). Doha was accordingly well provided with mosques (just over 40 in 1952). The most popular and important were the Sheikhs' Mosque next to the Amiri Diwan, the Al-Ahmad Mosque and the Qubib or Abu Qubib Mosque (also Qubaib, or Jubaib according to dialect, officially known as the Sheikh Jassim Mosque).
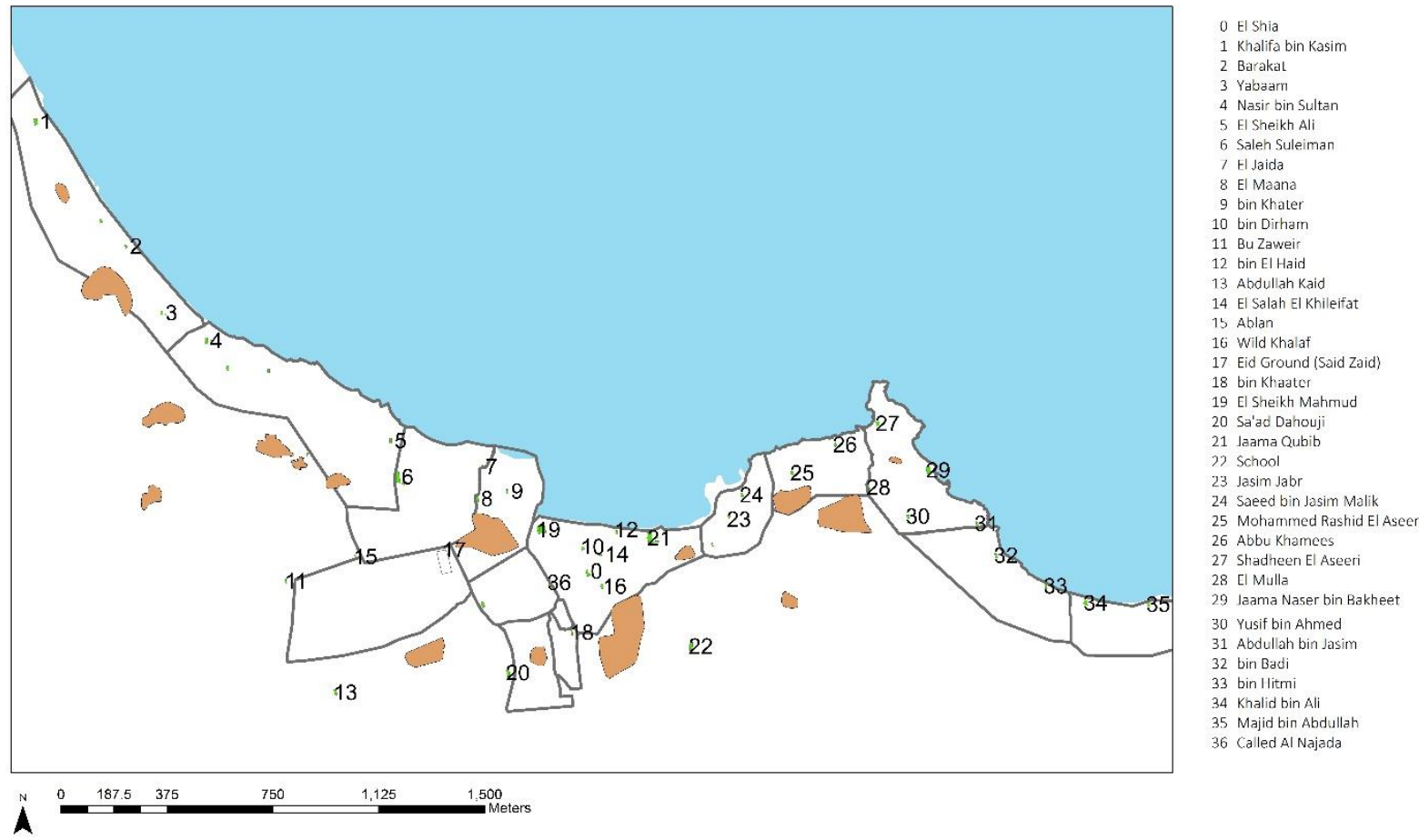

Figure 38: Named mosques 1952 with graveyards shown derived from Hunting Survey map of 1952 and using the transliteration from that source..

On average there was one mosque for every 200-300 people (depending on whether one accepts a lower or upper estimate of population of $8,000-12,000)$, and it is clear that some districts were better provided than others with mosques (fig. 32). This may reflect population density as well as endowment history (i.e. length of occupation): Farij Mohammed bin Jasim, for example largely consisted of Sheikh Mohammed bin Jassim's palace complex, rather than a densely inhabited housing district. Jasra was notable for its low density of housing and also has a high value, indicating relatively few mosques ${ }^{26}$.

\footnotetext{
26 There may be demographic reasons for this: the Shia population was concentrated in parts of Jasra, and it may have not been politically advisable for this community to build mosques.
} 
Doha may be well provided with mosques because of its comparative length of occupation (though this is not evident at Bida'), while Nejd may have a high number of mosques because of its dense housing.

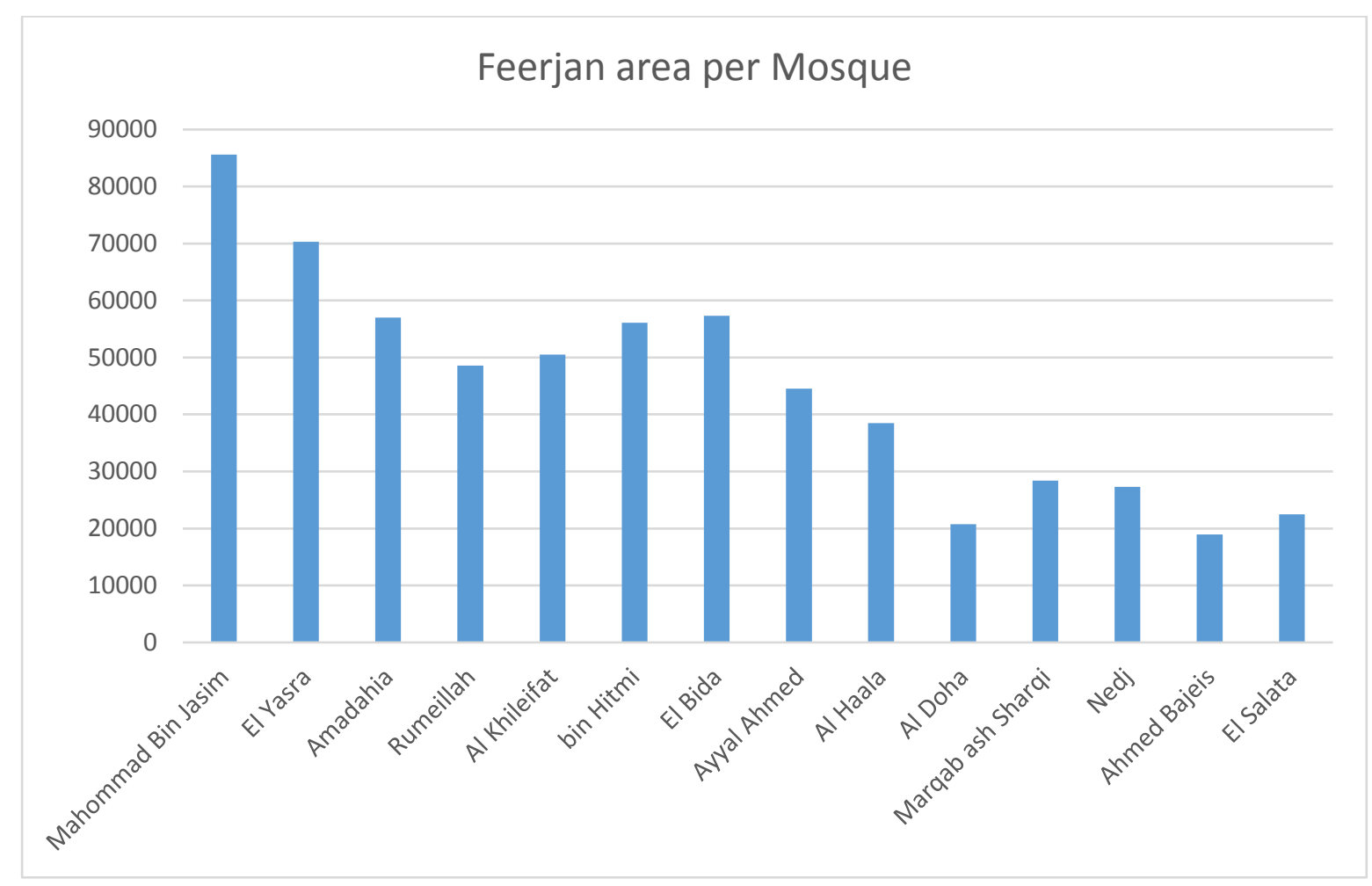

Figure 39: Ground area per mosque in each farij, in metres square per mosque. The higher the value the less-well provided the district is with mosques.

The largest public space in Doha, apart from the cemeteries, was the open air Eid prayer ground (mentioned in the quote by Othman above). This had a wall around it and was very large, measuring ca. $70 \times 180 \mathrm{~m}$, coming to 3,000 square metres, and was located to the south of Jasra, between the Kut fort and Farij Mohammed Bin Jassim. This was patronized by the sheikh and held the largest religious gatherings of the town.

Regarding the cemeteries, the conurbation prosessed at least twelve separate cemeteries, the largest being the Maqbarat Al-Doha just north of the Kut fort. They were named after adjacent districts and their inhabitants, and tend to mark the outside of the town at the time when oil revenues first arrived.

Finally, we note that Islamic law and customary law ('Urf) can influence the urban plan for example insofar as the need to avoid creating nuisance to others requires the location of noisy or dirty activities away from mosques and residential zones (Hakim 1994; Hakim 2008: 78-82). We note, however, that 
these are general considerations in urban living and are not exclusive to Islam, even if enshrined in the laws of Muslims. Moreover, as noted above with regard to the segregation of activities, Doha was most likely too small to house industries or dirty activities that were not already confined to the shoreline or docks by virtue of their function.

\section{Conclusions}

In its urban layout, physical development, architecture and pre-oil demographics, Doha combined its disparate cosmopolitan elements into a blend that most likely typified the historic Gulf town, and simultaneously encapsulated aspects of the generalised "Arab and Islamic town". The former requires further investigation, particularly given the lack of existing studies, and the consistent underestimation in local and international academic circles of the importance and millennial-scale antiquity of settled life and urbanism in eastern Arabia. We will therefore give similar treatment to a selection of other Gulf towns in a forthcoming comparative study.

One of the reassuring aspects of this study has been that theorists' characterization of the "Arab and Islamic town" (e.g. Raymond 2008), based on data from distant parts of the MENA region, has proved relevant to Doha. Our rigorous GIS-based approach has borne out many of the characteristics listed by Raymond. We have observed that while the traditional pre-oil town was not centrally planned, it was nonetheless structured. The lack of central planning is partially in agreement with the old orientalist conceptions of the Islamic town, which attributed seemingly chaotic urban development to a lack of municipal institutions (Raymond 2008: 49-50). However, whereas the orientalists saw chaos and attributed the lack of municipal oversight to the supposed shortcomings of oriental despotism, we see strong structuring principals at work which are embedded in the political and social matrix of the people of the region. Apart from establishing the validity of most of the principles listed by Raymond (especially segmentation, and initial compartmentalisation along community lines), we found analytical value in our own list of structuring principles, chosen to be relevant to the structure and development of a specifically Gulf town, particularly the role of patronage, defence, proximity to the sea and climate. Other considerations (location of water sources, mosques and general communication) are of phenomenological interest insofar as they relate intimately to the daily lived experience of the townspeople, but had a less obvious impact on the physical structure and social landscape of the town, save perhaps for identifying areas which were more conveniently located with regard to everyday life 
and employment. Using current evidence it is not possible to tell whether this can be related to zones of higher or lower wealth and status.

We also note that when oil revenues began to make their impact and central planning was instigated (in the early 1950s, considerably earlier than given credit by historians), all major infrastructural and housing enterprises were arranged through existing networks and patronage systems (in this case managed by Sheikh Ali bin Abdullah's closest adviser, chief executive and financier, Abdullah Darwish, effectively the Amir's vizier). The first major housing projects combined traditional architecture with modern planning, namely the $100 \times 50 \mathrm{~m}$ block system and the inner elements of the ring-road system (also developed significantly earlier than given credit by historians).

We found the strongest structuring principles, both in the traditional town and during its early modernisation phase, to be separation between zones of economic activity and residence; segmentary arrangement of districts; compartmentalisation of residence along kinship and community lines; and patronage. The latter three all relate are strongly associated with tribal social organization, though we stress that the historic population of Doha was neither overwhelmingly tribal in character nor entirely Arab in origin. Rather, these acted as prevailing ideologies, social structures and identities within a diverse and cosmopolitan population.

The prevalence of these ideologies, which are equally if not increasingly dynamic today in Qatar and the other GCC countries (Cooke 2014), is rooted not only in the perspective of the ruling families of the region but is also born of deep-seated local beliefs in the origins and lineage of the Arabic-speaking inhabitants of Arabia, namely that ultimately all are descended from nomadic desert tribes ${ }^{27}$. Thus, being Arab, tribal and nomadic are intrinsically linked and valorized in local understanding. The depth of this belief is indicated by the fact that the word used to denote urban districts (farij, pl. firjān) is the same used for tribal section and bedouin encampment (Fuccaro, 2009: 29-43). This creates obvious tensions in an urban context where nearly half of the national townspeople are not tribal, many of whom are demonstrably not of Arab lineage, and where even the more clearly tribal Arab groups are inheritors of a long urban and village tradition with no obvious bedouin forebears. While outright denial of the

\footnotetext{
27 See for example the statement that the "population [of Qatar] is of pure Arab stock ... descendants of the Bedouin tribes who still carry the name of their tribe and identify with it and who are known as the qabail" Melikian LH and Al-Easa J. 1981. Oil and Social Change in the Gulf. Journal of Arab Affairs 1: 79-98.
} 
diverse nature of Qatari society has sometimes been attempted (e.g. Melikian \& Al-Easa 1981), this diversity is privately acknowledged in local discourse and widely recognised in western academic circles.

We note that despite its demographic complexity, Doha's diverse populations evidently produced and inhabited mixed districts (e.g. Jasra, the old Doha quarters, Barahat Al-Jufairi) which are physically similar, even indistinguishable, from those associated with more obviously tribal and Arab groups (e.g. Kholaifat, Sulutah, Hitmi). Thus, we see a collective mode of urban living which seems to transcend ethnicity, sect and tribal organization, which we surmise is distinctively khaleeji, i.e. of the Gulf itself in character and origin, as much as it is Arab and Islamic. Our long-term archaeological perspective allows us to ascribe enormous antiquity to this urban tradition, significantly older than the existence of the ethnic, linguistic, social and religious distinctions that exist today. ${ }^{28}$ The broader relationship between this ancient tradition and Arab/lslamic architecture and urban structure must await another paper.

We further observe that within this inheritance of a common form of urbanism we see a maintenance of the social boundaries between the different population groups in Doha, up to the present day. Cooke (2014: 10) favours the Quranic term barzakh to describe the mixture of Qatari populations, parsed as "undiluted convergence", and implying a kind of co-mingling while retaining separate identities. We consider this an apt characterization, while noting that the co-mingling historically entailed the sharing of a set of architectural, social, cultural and economic behaviours.

Finally we note that, while it has become fashionable for historians, anthropologists and archaeologists to invoke the $14^{\text {th }}$ century north African theorist Ibn Khaldun as a critical starting point for the study of urbanism and settlement in the Arab world (e.g. Cooke 2014; Alshawi \& Gardner 2013; Gardner 2014; Bennison 2007; Magee 2014: 11; McCorriston 2011: 69), we do not share his vision of a cyclical and oppositional relationship between civilization (i.e. urbanism) and nomadic life with regard to the history of the towns of the Arabian shore ${ }^{29}$. Instead of bedouin tribes founding or reinvigorating urban life before

\footnotetext{
${ }^{28}$ The first towns on the Gulf littoral appeared during the early $4^{\text {th }}$ millennium BC in what is now southern Iraq, now marooned hundreds of kilometres inland by millennia of shoreline change. Settled (probably urban) life subsequently began during the second half of the fourth millennium BC in the Eastern Province of Saudi Arabia, and a fully urban indigenous civilization was in place in Bahrain and the Eastern province by the late $3^{\text {rd }}$ millennium BC. The first camel nomads appeared around 1000 years later in the Early Iron Age.

${ }^{29}$ We do however accept the importance of his concept of tribal solidarity (al-'asabiyyah) in both nomadic and settled Arabian society, again reiterating that this has been both consciously and unconsciously used to mask the true demographic complexity of towns such as Doha.
} 
falling themselves into corruption and decay (to be followed by a subsequent injection of vigour from the desert, and so on ad infinitum), we rather see a continuous movement of settled peoples between the towns and villages on both sides of the Gulf, Arab and non-Arab, sometimes supplemented by population movement from inland areas of Arabia, largely by hadr, i.e. settled peoples, not bedouin. Thus, although economic integration and a degree of population exchange with both a nomadic and settled hinterland has been significant for millennia, we do not see a Khaldunian cycle but rather longterm urban integration and symbiosis between the people of the sea, the oasis and the desert. In the traditional town of Doha we see the tail end of this immensely long khaleeji urban tradition. 
Abu-Lughod J.L. 1987. The Islamic City--Historic Myth, Islamic Essence, and Contemporary Relevance. International Journal of Middle East Studies 19(2):155-176.

Abu Saud A. 1984. Qatari Women, Past and Present. London: Longman.

Alraouf, A.A., 2012. A Tale of Two Souqs: The Paradox of Gulf Urban Diversity. Open House International, 37(2).

Alshawi, A.H. \& A. Gardner, 2013. Tribalism, Identity andf Citizenship in Contemporary Qatar. Anthropology of the MIddle East, 8.2, 46-59.

Al-Sulaiti, A., 2009. Muharraq City: a GIS-based planning strategy for its ancient heritage conservation. PhD Dissertation, University of Portsmouth.

Anon. 1986. Persian Gulf Administration Reports: 1873-1920, vols. I-VII. Gerrards Cross: Archive Editions.

Anon. 1987. The Persian Gulf trade reports, 1905-1940. Gerrards Cross: Archive Editions.

Arnoldi A.D. 1600. Asia. Siena: Mathej Florimj for. Senis.

Bandyopadhyay, S., 2010. Manah: Omani Oasis, Arabian legacy; architecture and social history of an Omani Oasis settlement, Liverpool \& Muscat: Liverpool University Press \& Historical Association of Oman.

Bandyopadhyay, S., G. Quattrone, M. Goffriller, P. MacMahon, J. Wren, S. Ghinita \& H. Al-'Abri, 2015a. Al-Qabil: Mudayrib. Documentation and Heritage Management Plan, Muscat: Ministry of Heritage and Culture, Sultanate of Oman; Centre for the Study of Architecture and Cultural Heritage of India, Arabia and the Maghreb, Nottingham Trent Univeristy.

Bandyopadhyay, S., G. Quattrone, M. Goffriller, P. MacMahon, J. Wren, S. Ghinita, H. Al-'Abri, H. AlFarsi \& M. Alissai, 2015b. Sinaw: Harat Al Bu Rashid \& Harat As-Suwawfah. Documentation and Heritage Management Plan, Muscat: Ministry of Heritage and Culture, Sultanate of Oman; Centre for the Study of Architecture and Cultural Heritage of India, Arabia and the Maghreb, Nottingham Trent Univeristy.

Bendix R. 1977. Max Weber: An Intellectual Portrait. Berkeley: University of California Press.

Bennison, A.K., 2007. Introduction. In Cities in the pre-modern Islamic world: The urban impact of religion, state and society, eds. A.K. Bennison \& A.L. Gascoigne. London \& New York: Routledge, 1-12.

Biedermann Z., Couto D., Bacqué-Grammont J.-L., and Taleghani M. 2006. Atlas historique du golfe Persique (XVIe-XVIIle siècles) / Historical Atlas of the Persian Gulf (Sixteenth to Eighteenth Centuries). Turnhout: Orbis Terrarum. Brepols.

Billecocq X.B. 2008. Qatar and the French: Five centuries of travel writings and scholarly texts. Paris: Collection Relations Internationales \& Culture.

Birks J.S., and Sinclair C.A. 1979. International labour migration in the Arab middle east. Third World Quarterly 1(2):87-99.

Boussaa, D., 2006. A future to the past: the case of Farij Al-Bastakia in Dubai, UAE, in Proceedings of the Seminar for Arabian Studies, 125-38.

Boussaa, D., 2014a. Rehabilitation as a Catalyst of Sustaining a Living Heritage: The Case of Souk Waqif in Doha, Qatar. Art and Design Review, 2(03), 62.

Boussaa, D., 2014b. Al Asmakh historic district in Doha, Qatar: from an urban slum to living heritage. Journal of Architectural Conservation, 20(1), 2-15.

Brucks G.B. 1985. Memoir Descriptive of the Navigation of the Gulf of Persia. In Selections from the Records of the Bombay Government, No XXIV. Ed. Hughes, Thomas R. New York: Oleander Press.

Brun T.A., Geissler C., and Bel F. 1977. Le Baloutchistan iranien. Un réservoir de travailleurs sousalimentés pour les Émirats. Tiers-Monde 18 (69):131-138.

Burchardt H. 1906. Ost-Arabien von Basra bis Muscat auf Grund eigener Reisen. Zeitschrift der Gesellschaft fur Erdkunde zu Berlin 1906:305-322.

Burdett A.L.P. 1994. The GCC States, National Development Records: Civil Aviation 1920-1962, London: Archive Editions.

Burdett A.L.P. 2006. Records of Qatar, 1966-1971. Slough: Archive Editions.

Carter R.A. 2012. Sea of pearls : seven thousand years of the industry that shaped the Gulf. London: Arabian. xx, 363 p. p.

Carter, R.A. \& D. Eddisford, 2013. Origins of Doha Project: Season 1. Archive Report, https://originsofdoha.files.wordpress.com/2013/11/origins-of-doha-season-1-archive-reportfinal.pdf.

Clarke K.C., and Gaydos L.J. 1998 Loose-coupling a cellular automaton model and GIS: long-term urban growth prediction for San Francisco and Washington/Baltimore. Int J Geogr Inf Sci 12(7):699-714.

Constable C.G., and Stiffe A.W. 1989. The Persian Gulf Pilot including the Gulf of Oman, 1864. Oxford: Archive Editions. 
ESRI. 2014. How cost distance tools work.

http://resources.arcgis.com/en/help/main/10.2/\#/How the cost distance tools_work/009z000 00025000000/.

Cooke M. 2014. Tribal Modern: Branding New Nations in the Arab Gulf, Berkeley: University of California Press.

Carter, R.A. \& D. Eddisford, 2015. Report on Architectural Recording and Archaeological Survey Undertaken at Nu'aija, Doha. Unpublished report of the Origins of Doha and Qatar Project.

Carter, R.A. \& D. Eddisford, 2013. Origins of Doha Project: Season 1. Archive Report,

https://originsofdoha.files.wordpress.com/2013/11/origins-of-doha-season-1-archive-report-final.pdf

Fuccaro, N. 2014. Rethinking the Hbistory of Port Cities in the Gulf. In The Persian Gulf in Modern Times: People, Ports, and History, ed. L.G. Potter. Palgrave Macmillan: 23-46.

Fuccaro N. 2009. Histories of City and State in the Persian Gulf: Manama since 1800. Cambridge: Cambridge University Press.

Gardner, A.M., 2011. Gulf migration and the family. Journal of Arabian Studies, 1(1), 3-25.

Gardner A. M. 2014. How the City Grows. Urban Growth and Challenges to Sustainable Development in Doha, Qatar. In Sustainable development : an appraisal from the Gulf Region, Ed. Sillitoe P. New York: Berghahn Books, 333-366.

Graham H. 1978. Arabian time machine: self-portrait of an oil state: Holmes \& Meier Publishers.

Guindi F.E. 2008. By Noon Prayer: The Rhythm of Islam: Bloomsbury Academic.

Hadi Alshawi A. 2002. Political Influences of Tribes in the State of Qatar: Impact of Tribal Loyalty on Political Participation. Starkville: Mississippi State University.

Hadi Alshawi A., and Gardner A. 2013. Tribalism, Identity and Citizenship in Contemporary Qatar. Anthropology of the Middle East 8(2):46-59.

Haider D. 2008. The Growing Pains of Dubai: A City in Search of its Identity. In The City in the Islamic World, eds. Jayyusi, S.K., Holod, R., Petruccioli, A., and Raymond A. Brill:1063-1084.

Hourani A. 1970. Introduction: The Islamic City in Light of Recent Research. The Islamic City. Oxford: Bruno Cassirer: 9-24.

Hay, R., 1959 The Persian Gulf States. Middle East Institute, Washington DC.

Hay, R., 1955. The Impact of the Oil Industry on the Persian Gulf Shaykhdoms. Middle East Journal, 9(4), 361-72.

Hughes T., R. 1985. Arabian Gulf intelligence : concerning Arabia, Bahrain, Kuwait, Muscat and Oman, Qatar, United Arab Emirates and the islands of the Gulf. Cambridge: Oleander. xxvii, 687 p., 686 folded leaves of plates.

Jayyusi, S.K., R. Holod, A. Petruccioli \& A. Raymond (eds.), 2008. The City in the Islamic World: Brill.

Khalifa H.A., and Rice M. 1986. Bahrain through the ages: the archaeology. London: Routledge.

Kurşun Z. 2002. The Ottomans in Qatar : a history of Anglo-Ottoman conflicts in the Persian Gulf. Istanbul: Isis Press.

Lespès R. 1930. Alger. Etude de géographie et d'histoire urbaines. Paris: Alcan.

Lewcock R.T. 1978. Traditional Architecture in Kuwait and the Northern Gulf. London: Art and Archaelogy Research Papers

Lorimer J.G. 1915. Gazetteer of the Persian Gulf : 'Oman, and Central Arabia. Calcutta

India,: Superintendent Government Printing.

Lorimer J.G. 1908. Tribes and the Towns of Qatar, Geographical and Statistical, vol. IIB, Gazetteer of the Persian Gulf : 'Oman, and Central Arabia. Calcutta, India,: Superintendent Government Printing

Magee P. 2014. The Archaeology of Prehistoric Arabia: Adaptation and Social Formation from the Neolithic to the Iron Age: Cambridge University Press.

Marçais G. 1957. L'urbanisme musulman (= Conférence, faite à la séance inaugurale du cinquième congrès des Sociétés savantes. - Tunis, 1939, publiée par la Revue africaine, 1939-1940, pp. 13-34), p. 219-. Mélanges d'Histoire et d'Archéologie de l'Occident Musulman. Alger: Imprimerie Officielle.

McCorriston J. 2011. Pilgrimage and Household in the Ancient Near East: Cambridge University Press.

Melikian L.H., and Al-Easa J. 1981. Oil and Social Change in the Gulf. Journal of Arab Affairs 1(1):7998.

Nagy S. 1997. Social and spatial process: An ethnographic study of housing in Qatar. Ann Arbor: University of Pennsylvania.

Nagy S. 1998. Social diversity and changes in the form and appearance of the Qatari house. Visual Anthropology 10(2-4):281-304.

Nagy S. 2006. Making Room for Migrants, Making Sense of Difference: Spatial and Ideological Expressions of Social Diversity in Urban Qatar. Urban Studies 43(1):119-137. 
Nakib, F., 2011. Kuwait City: Urbanisation, the Built Environment, and the Urban Experience Before and After Oil (1716-1986): Thesis submitted for the degree of PhD in History, Exeter University.

Othman N. 1984. With Their Bare Hands: The Story of the Oil Industry in Qatar. London: Longman.

Palgrave W.G. 1866. Personal narrative of a year's journey through central and eastern Arabia (186263). London: Macmillan and co.

Petersen A., and Grey A. 2010. Excavations and survey at al-RuwayPah,a late Islamic site in northern Qatar. Proceedings of the Seminar for Arabian Studies 40:41-54.

Potts D.T. 1990. The Arabian Gulf in antiquity. Volume 1: from prehistory to the Fall of the Achaemenid Empire. Oxford: Clarendon.

Rahman H. 2005. The emergence of Qatar : the turbulent years, 1627-1916. London: Kegan Paul. $x x x, 282$ pages $p$.

Raymond A. 1994. Islamic City, Arab City: Orientalist Myths and Recent Views. British Journal of Middle Eastern Studies 21(1):3-18.

Raymond A. 2008. The Spatial Organization of the City. In The City in the Islamic World, eds. Jayyusi S.K., Holod R., Petruccioli A., and Raymond A. Brill: 47-70.

Saldanha J.A. 1986. The Persian Gulf Précis: Précis of Nejd affairs, 1804-1904; Précis of Koweit affairs, 1896-1904; Précis of Turkish expansion on the Arab Littoral of the Persian Gulf and Hasa and Katif affairs: Archive Editions.

Sauvaget J. 1934. Esquisse d'une histoire de la ville de Damas. Revue des Études Islamiques 4: 422480.

Seccombe I.J. 1983. Labour migration to the Arabian Gulf: evolution and characteristics 1920-1950. Bulletin of the British Society for Middle Eastern Studies 10(1):3-20.

Shepperson 2009 Planning for the sun: urban forms as a Mesopotamian response to the sun. World Archaeology 41.3: 363-378

Teixeira P., Sinclair W.F., Ferguson D.W., and Stevens J. 1902. The travels of Pedro Teixeira : with his "Kings of Harmuz" and extracts from his "Kings of Persia". London: Printed for the Hakluyt Society. cvii, 292 p. p.

Tourneau R. L. 1957. Les Villes musulmanes de l'Afrique du Nord: La Maison des Livres (Impr. officielle).

Trench R. 1994. Arab Gulf cities, [Gerrards Cross (GB)]: Archive ed.

Tuan Y. 1977. Space and Place: The Perspective of Experience. Minneapolis: University of Minnesota Press.

Tuson P. 1991. Records of Qatar 1820-1960. London: Archive Editions Limited.

Villiers A. 1940. Sons of Sinbad. London: Hodder \& stoughton.

von Grunebaum G. 1955. The Structure of the Muslim Town. In Islam: Essays in the Nature and Growth of a Cultural Tradition, Memoir No. 81. Ann Arbor: The American Anthropological Association, 141-158.

Waldseemüller M. 1507. Universalis cosmographia secundum Ptholomaei traditionem et Americi Vespucii alioru[m]que lustrationes. St. Dié, France.

Weulersse J., and Demangeon A. 1935. Antioche essai de géographie urbaine. Le Caire: Impr. de I'Institut français d'archéologie orientale.

Yarwood, J., 1988. Al Muharraq: Architecture, Urbanism and Society in an Historic Arabian Town, Department of Architecture Sheffield: University of Sheffield.

Yarwood JR. 1999. Traditional Building Construction in an Historic Arabian Town. Construction History 15: 57-77.

Yarwood, J., 2005. Al-Muharraq: Architectural Heritage of a Bahraini City, Manama: Shaikh Ebrahim bin Mohammed al-Khalifa Centre for Culture and Research, Bahrain.

Wilton, J., n.d. Unpublished memoir, Qatar and Sharjah 1949-1952. Lodged at ST Anthony's College, Oxford.

Zahlan R.S. 1979. The Creation of Qatar. London: HJarper \& Row. 